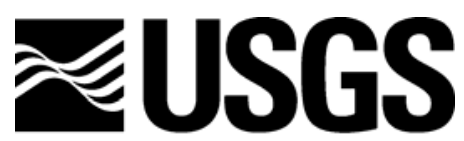

science for a changing world

Prepared in cooperation with

U.S. Environmental Protection Agency

\title{
Sequential Extraction Results and Mineralogy of Mine Waste and Stream Sediments Associated with Metal Mines in Vermont, Maine, and New Zealand
}

By N. M. Piatak, R. R. Seal II, R.F. Sanzolone, P. J. Lamothe, Z. A. Brown, and M. Adams

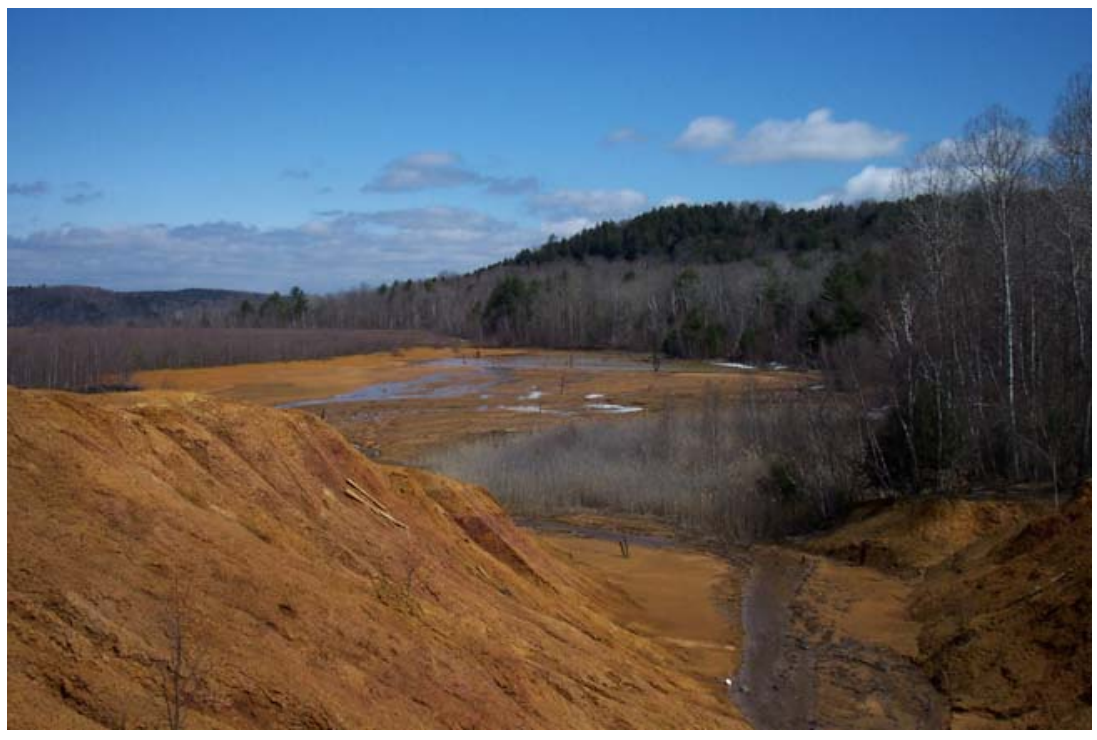

Open-File Report 2007-1063

U.S. Department of the Interior

U.S. Geological Survey 


\section{U.S. Department of the Interior Dirk Kempthorne, Secretary}

\section{U.S. Geological Survey Mark Myers, Director}

\section{U.S. Geological Survey, Reston, Virginia 2007}

This publication is available online at http://pubs.usgs.gov/of/2007/1063/

For product and ordering information: World Wide Web: http://www.usgs.gov/pubprod

Telephone: 1-888-ASK-USGS

For more information on the USGS - the Federal source for science about the Earth, its natural and living resources, natural hazards, and the environment: World Wide Web: http://www.usgs.gov

Telephone: 1-888-ASK-USGS

Suggested citation:

Piatak, N.M., Seal, R.R., II, Sanzolone, R.F., Lamothe, P.J., Brown, Z.A. Adams, M., 2007, Sequential Extraction Results and Mineralogy of Mine Waste and Stream Sediments Associated with Metal Mines in Vermont, Maine, and New Zealand: U.S. Geological Survey Open-File Report 2007-1063, 34 p.

Any use of trade, product, or firm names is for descriptive purposes only and does not imply endorsement by the U.S. Government.

Although this report is in the public domain, permission must be secured from the individual copyright owners to reproduce any copyrighted material contained within this report. 


\section{Contents}

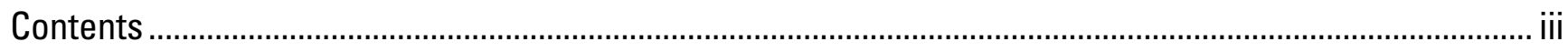

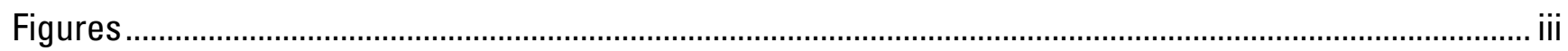

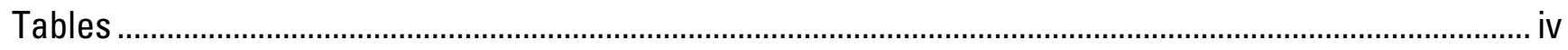

Abstract

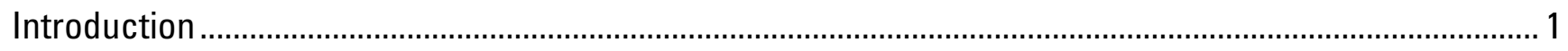

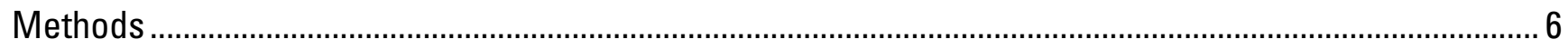

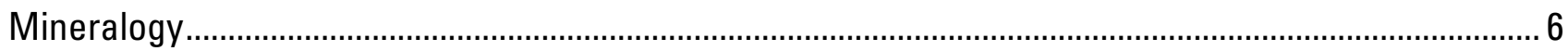

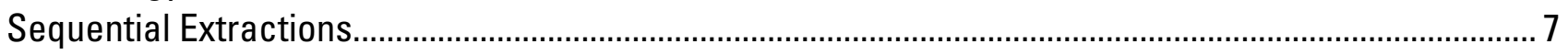

Results

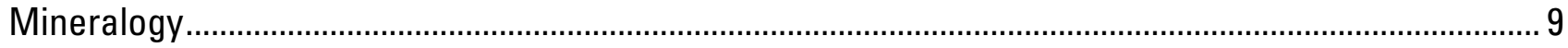

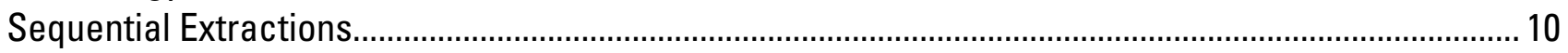

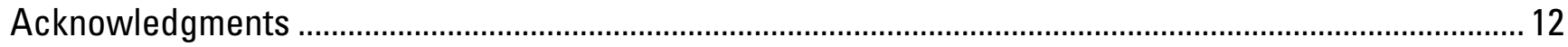

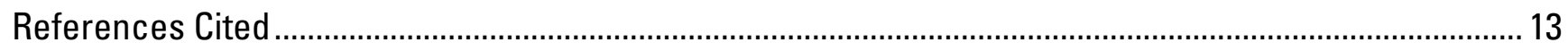

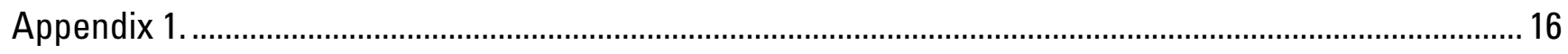

Appendix 2.

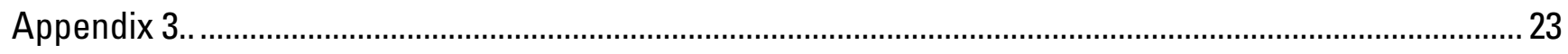

\section{Figures}

Figure 1. Locations of samples from the Elizabeth Mine. The north toe of TP1 has been regraded to a less steep slope, and stream-sediment samples were collected after regrading............................... 2

Figure 2. Locations of samples from the Ely Copper Mine. Modified from Piatak and others (2004)........ 3

Figure 3. Locations of samples from the Pike Hill Copper Mines. Modified from Piatak and others (2006c); original base map from White and Eric (1944).

Figure 4. Location of sample from the Callahan Mine. Modified from MACTEC (2006)............................... 6

Figure 5. Schematic of sequential extraction procedure. After extract step 5 , half of sample was digested and analyzed by ICP-MS and HG-AAS and the other half was treated in step 6 . Because of the potential volatilization of sulfide and selenides in step 6, element concentrations in extract 6 were calculated from the difference between the concentration in the residue from step 5 and that in residue from step 6 .

Figure 6. Calculated iron $(\mathrm{Fe})$ and calcium $(\mathrm{Ca})$ totals from extractions versus total from untreated samples. Calculated totals are the sum of an element in extracts $1,2,3,4$, and 5 and in the residue after step 5 . Zero was used for concentrations less than the detection limit. The black line represents a 1:1 correlation and the red dashed lines represent the analytical uncertainty of $\pm 10 \%$.

Figure 7. Calculated arsenic (As), copper (Cu), selenium (Se), and zinc (Zn) totals from extractions versus total from untreated samples. Calculated totals are the sum of an element in extracts 1,2, 3,4 , and 5 and in the residue after step 5 . Zero was used for concentrations less than the detection limit. The black line represents a 1:1 correlation and the red dashed lines represent the analytical uncertainty of $\pm 10 \%$. 


\section{Tables}

Table 1. Sample descriptions.

\section{Conversion Factors}

\section{SI to Inch/Pound}

\begin{tabular}{lll}
\hline Multiply & By & To obtain \\
\hline Length & & \\
\hline centimeter (cm) & 0.3937 & inch (in.) \\
millimeter (mm) & 0.03937 & inch (in.) \\
meter (m) & 3.281 & foot (ft) \\
kilometer (km) & 0.6214 & mile (mi) \\
meter (m) & 1.094 & yard (yd) \\
\hline liter (L) & 33.82 & ounce, fluid (fl. oz) \\
liter (L) & 2.113 & pint (pt) \\
liter (L) & 1.057 & quart (qt) \\
liter (L) & 0.2642 & gallon (gal) \\
\hline Mass & & \\
\hline gram (g) & 0.03527 & ounce, avoirdupois (oz) \\
kilogram (kg) & 2.205 & pound avoirdupois (lb) \\
\hline
\end{tabular}

Temperature in degrees Celsius $\left({ }^{\circ} \mathrm{C}\right)$ may be converted to degrees Fahrenheit $\left({ }^{\circ} \mathrm{F}\right)$ as follows: ${ }^{\circ} \mathrm{F}=\left(1.8 \times{ }^{\circ} \mathrm{C}\right)+32$ 


\title{
Sequential Extraction Results and Mineralogy of Mine Waste and Stream Sediments Associated with Metal Mines in Vermont, Maine, and New Zealand
}

\author{
By N. M. Piatak', R. R. Seal II', R.F. Sanzolone², P. J. Lamothe², Z. A. Brown², and M. Adams²
}

\begin{abstract}
We report results from sequential extraction experiments and the quantitative mineralogy for samples of stream sediments and mine wastes collected from metal mines. Samples were from the Elizabeth, Ely Copper, and Pike Hill Copper mines in Vermont, the Callahan Mine in Maine, and the Martha Mine in New Zealand. The extraction technique targeted the following operationally defined fractions and solid-phase forms: (1) soluble, adsorbed, and exchangeable fractions; (2) carbonates; (3) organic material; (4) amorphous iron- and aluminum-hydroxides and crystalline manganese-oxides; (5) crystalline iron-oxides; (6) sulfides and selenides; and (7) residual material. For most elements, the sum of an element from all extractions steps correlated well with the original unleached concentration. Also, the quantitative mineralogy of the original material compared to that of the residues from two extraction steps gave insight into the effectiveness of reagents at dissolving targeted phases. The data are presented here with minimal interpretation or discussion and further analyses and interpretation will be presented elsewhere.
\end{abstract}

\section{Introduction}

Sequential partial dissolutions were used to characterize the distribution of elements in stream sediments, mine wastes, and flotation-mill tailings from several metal mines. The procedure was developed to extract metals associated with operationally defined solid phases to provide insight into speciation and possible bioavailability. This study was prompted by concerns about the potential environmental impact of elevated selenium concentrations in stream sediments raised by the preliminary Baseline Ecological Risk Assessment (BERA) at the Elizabeth Mine in Vermont. Additional samples from elsewhere in the Vermont copper belt and beyond were selected for comparison purposes. The distribution of selenium in extraction fractions and implications with respect to potential bioavailability were discussed by Piatak and others $(2006 \mathrm{a} ; 2006 \mathrm{~b})$. This report presents the results of the major and trace elements in unleached samples and in extracts and residues from the dissolutions. Also, quantitative mineralogy of the original samples and several residues was included.

Samples were collected from the Elizabeth (fig. 1), Ely Copper (fig. 2), and Pike Hill Copper (fig. 3) mines, all Superfund sites in the Vermont copper belt, and include stream sediments, oxidized mine waste, and flotation-mill tailings (table 1). These deposits, mined primarily for copper and zinc, are Besshi-type massive sulfide deposits composed of pyrrhotite,

\footnotetext{
${ }^{1}$ U.S. Geological Survey, 12201 Sunrise Valley Dr., Reston, VA 20192
}

${ }^{2}$ U.S. Geological Survey, Denver Federal Center, Denver, CO 80225 
chalcopyrite, and minor sphalerite and pyrite (Slack and others, 2001). Fine-grained flotationmill tailings from the Callahan Mine, a Superfund site in Brooksville, Me., were also collected (table 1 and fig. 4). This mine exploited a Kuroko-type massive sulfide deposit that contained bodies of pyrite, sphalerite, and chalcopyrite that were mined for zinc, copper, lead, and gold (Bouley and Hodder, 1984). Flotation-mill tailings were also examined from the Martha Mine in Waihi, New Zealand, which is an epithermal gold-silver deposit (Castendyk and others, 2005) (table 1).

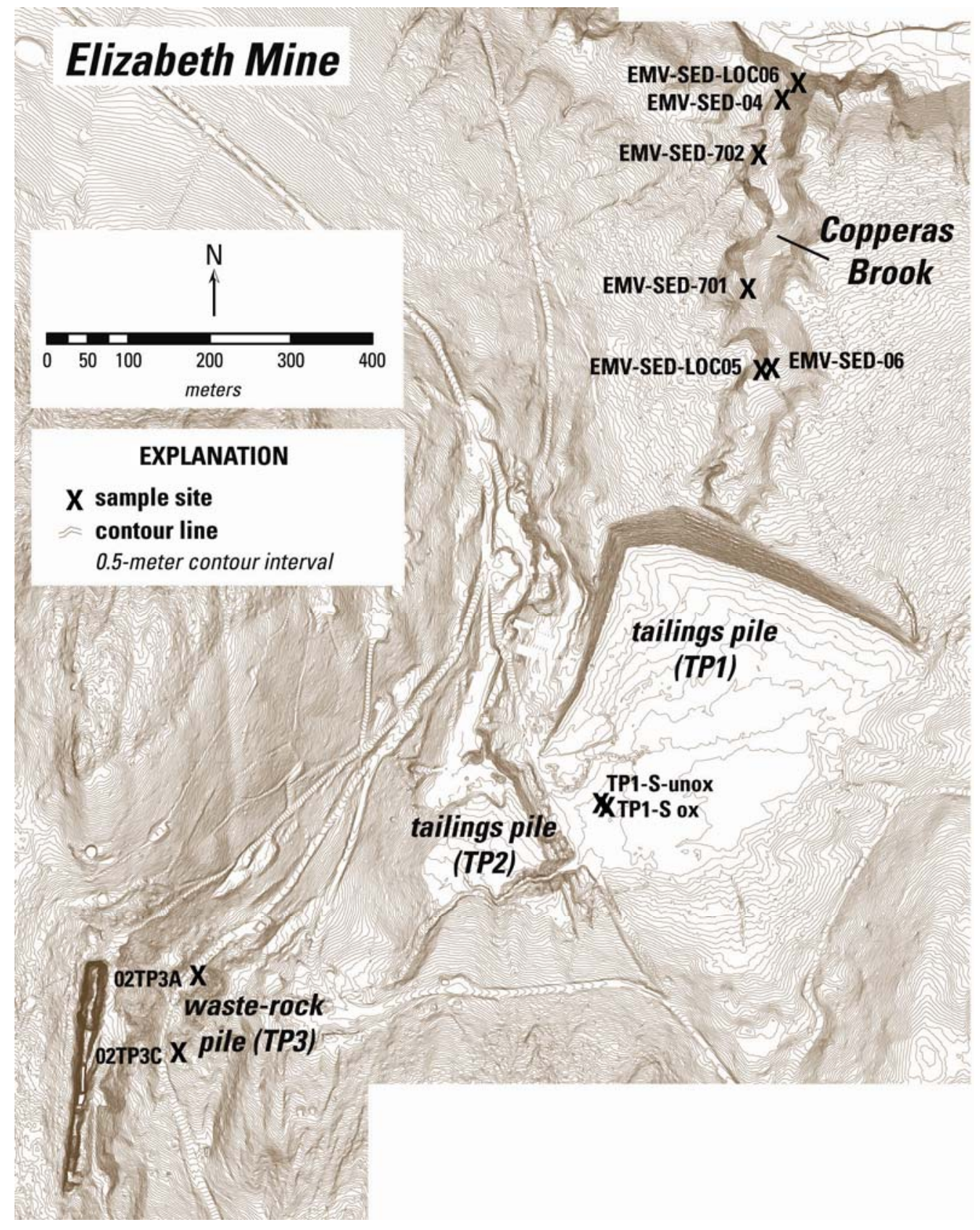

Figure 1. Locations of samples from the Elizabeth Mine. The north toe of TP1 has been regraded to a less steep slope, and stream-sediment samples were collected after regrading. 


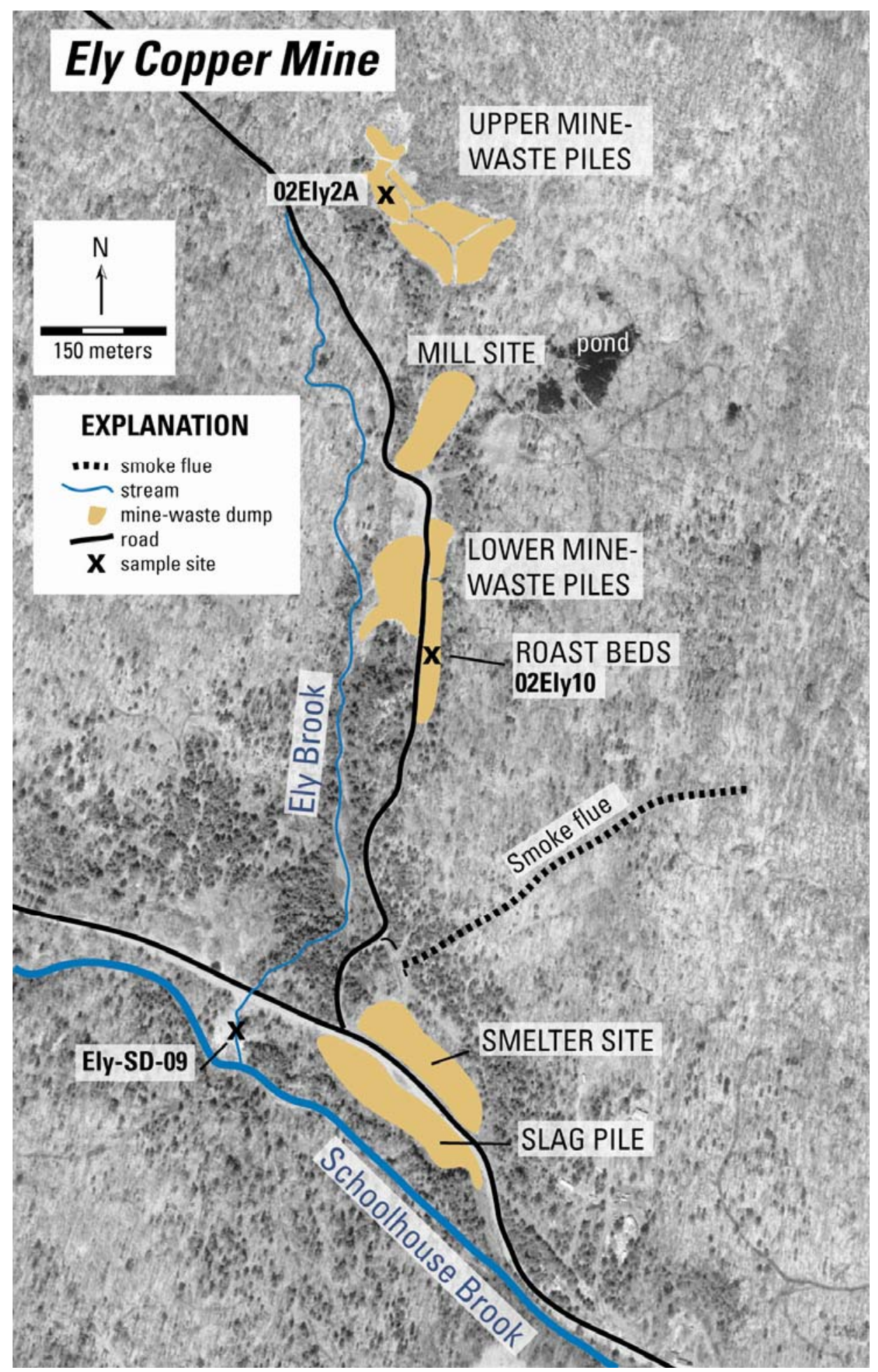

Figure 2. Locations of samples from the Ely Copper Mine. Modified from Piatak and others (2004). 


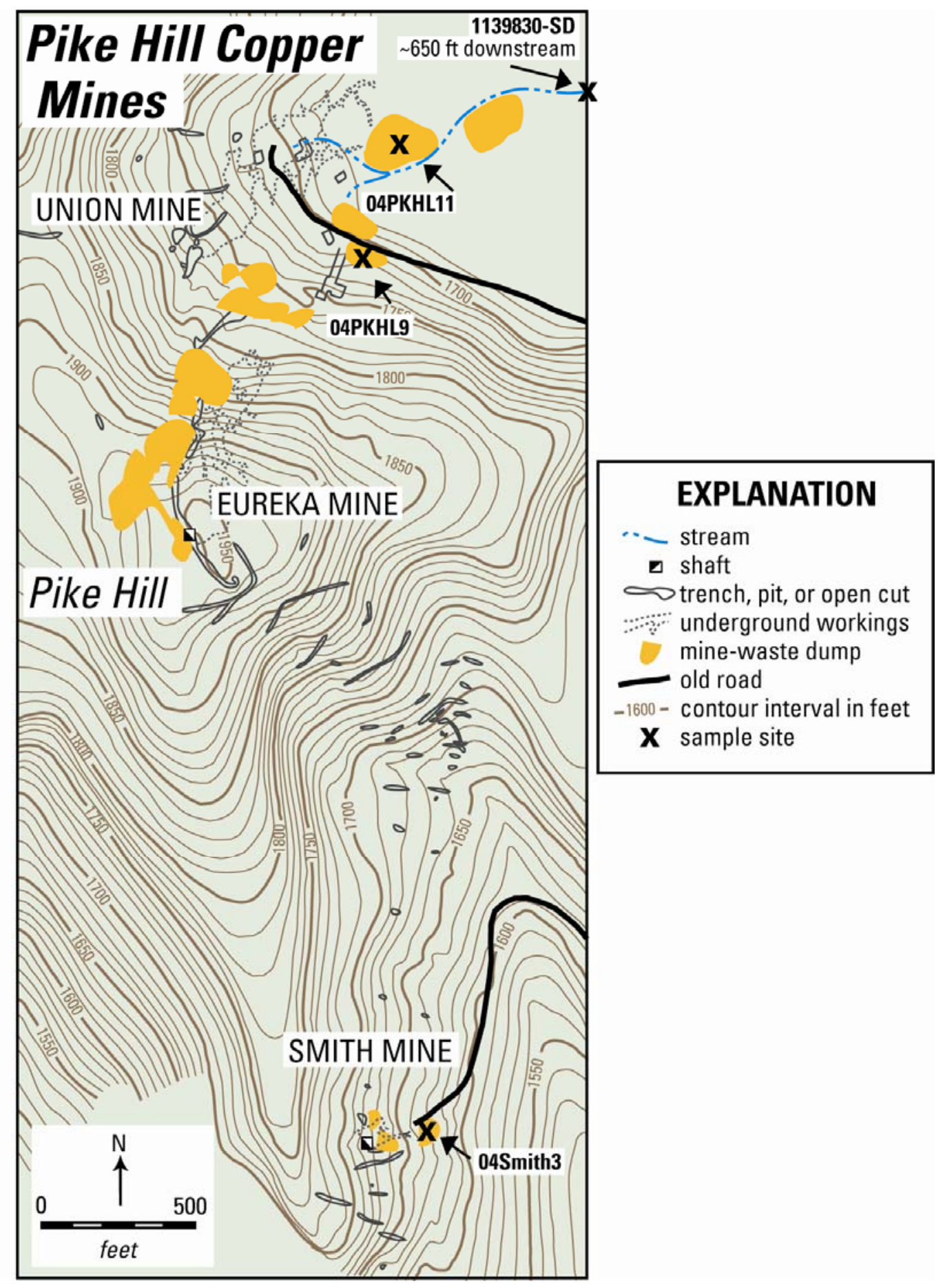

Figure 3. Locations of samples from the Pike Hill Copper Mines. Modified from Piatak and others (2006c); original base map from White and Eric (1944). 
Table 1. Sample descriptions

\begin{tabular}{|c|c|c|c|c|c|c|c|c|c|c|}
\hline Sample ID & Extract ID & Mine & Type & Locations & Soil Color & Latitude & Longitude & Date & Method & Preparation \\
\hline Blank & $\mathrm{A}$ & - & Blank & Blank & - & - & - & - & - & None \\
\hline $\begin{array}{l}\text { EMV-SED- } \\
\text { LOC05 }\end{array}$ & $\mathrm{B}$ & Elizabeth & $\begin{array}{l}\text { Stream } \\
\text { sediment }\end{array}$ & $\begin{array}{l}\text { Copperas Brook below weir at sediment } \\
\text { basin outlet. }\end{array}$ & $\begin{array}{l}\text { Brownish } \\
\text { yellow }\end{array}$ & 43.82814 & -72.32739 & $\begin{array}{l}\text { June- } \\
05\end{array}$ & Grab & $\begin{array}{l}\text { Dry sieved }<2 \\
\mathrm{~mm}\end{array}$ \\
\hline $\begin{array}{l}\text { EMV-SED- } \\
\text { LOC05-Dup1 }\end{array}$ & $\mathrm{C}$ & Elizabeth & $\begin{array}{l}\text { Stream } \\
\text { sediment }\end{array}$ & $\begin{array}{l}\text { Copperas Brook below weir at sediment } \\
\text { basin outlet. Duplicate. }\end{array}$ & $\begin{array}{l}\text { Brownish } \\
\text { yellow }\end{array}$ & 43.82814 & -72.32739 & $\begin{array}{l}\text { June- } \\
05\end{array}$ & Grab & $\begin{array}{l}\text { Dry sieved }<2 \\
\mathrm{~mm}\end{array}$ \\
\hline $\begin{array}{l}\text { EMV-SED- } \\
\text { LOC06 }\end{array}$ & $\mathrm{D}$ & Elizabeth & $\begin{array}{l}\text { Stream } \\
\text { sediment }\end{array}$ & Copperas Brook below flume at mouth. & Strong brown & 43.83129 & -72.32686 & $\begin{array}{l}\text { June- } \\
05\end{array}$ & Grab & $\begin{array}{l}\text { Dry sieved }<2 \\
\mathrm{~mm}\end{array}$ \\
\hline EMV-SED-04 & $\mathrm{E}$ & Elizabeth & $\begin{array}{l}\text { Stream } \\
\text { sediment }\end{array}$ & $\begin{array}{l}\text { Copperas Brook upstream of flume at } \\
\text { mouth. }\end{array}$ & Strong brown & 43.83112 & -72.32710 & $\begin{array}{l}\text { June- } \\
05\end{array}$ & Grab & $\begin{array}{l}\text { Dry sieved }<2 \\
\mathrm{~mm}\end{array}$ \\
\hline EMV-SED-06 & $\mathrm{F}$ & Elizabeth & $\begin{array}{l}\text { Stream } \\
\text { sediment }\end{array}$ & $\begin{array}{l}\text { Copperas Brook down-gradient of decant } \\
\text { and sediment basin drainage confluence. }\end{array}$ & Strong brown & 43.82814 & -72.32730 & $\begin{array}{c}\text { June- } \\
05\end{array}$ & Grab & $\begin{array}{l}\text { Dry sieved }<2 \\
\mathrm{~mm}\end{array}$ \\
\hline EMV-SED-701 & G & Elizabeth & $\begin{array}{l}\text { Stream } \\
\text { sediment }\end{array}$ & $\begin{array}{l}\text { Copperas Brook at confluence with decant } \\
\text { diversion. }\end{array}$ & $\begin{array}{l}\text { Dark yellowish } \\
\text { brown }\end{array}$ & 43.82903 & -72.32760 & $\begin{array}{l}\text { June- } \\
05\end{array}$ & Grab & $\begin{array}{l}\text { Dry sieved }<2 \\
\mathrm{~mm}\end{array}$ \\
\hline EMV-SED-702 & $\mathrm{H}$ & Elizabeth & $\begin{array}{c}\text { Stream } \\
\text { sediment }\end{array}$ & $\begin{array}{l}\text { Copperas Brook downstream of confluence } \\
\text { with decant diversion. }\end{array}$ & Strong brown & 43.83050 & -72.32746 & $\begin{array}{c}\text { June- } \\
05\end{array}$ & Grab & $\begin{array}{l}\text { Dry sieved }<2 \\
\mathrm{~mm}\end{array}$ \\
\hline Ely-SD-09 & I & Ely Copper & $\begin{array}{l}\text { Stream } \\
\text { sediment }\end{array}$ & $\begin{array}{l}\text { Ely Brook downstream of culvert, upstream } \\
\text { of confluence with Schoolhouse Brook }\end{array}$ & Strong brown & 43.91873 & -72.28652 & $\begin{array}{l}\text { Dec-1- } \\
05\end{array}$ & Composite & $\begin{array}{l}\text { Dry sieved }<2 \\
\mathrm{~mm}\end{array}$ \\
\hline 1139830-SD & $\mathrm{J}$ & $\begin{array}{l}\text { Pike Hill } \\
\text { Copper }\end{array}$ & $\begin{array}{l}\text { Stream } \\
\text { sediment }\end{array}$ & $\begin{array}{l}\text { Pike Hill Brook above Richardson Road at } \\
\text { weir. }\end{array}$ & Strong brown & 44.06389 & -72.30194 & $\begin{array}{l}\text { Aug-2- } \\
05\end{array}$ & Composite & $\begin{array}{l}\text { Dry sieved } \\
<180 \mu \mathrm{m}\end{array}$ \\
\hline 04Smith3 & $\mathrm{K}$ & $\begin{array}{l}\text { Pike Hill } \\
\text { Copper }\end{array}$ & Mine waste & $\begin{array}{l}\text { Lowermost mine-waste dump below main } \\
\text { adit at the Smith mine. }\end{array}$ & Olive yellow & 44.05464 & -72.30517 & $\begin{array}{c}\text { Oct- } \\
19-04\end{array}$ & Composite & $\begin{array}{l}\text { Dry sieved }<2 \\
\mathrm{~mm}\end{array}$ \\
\hline CLHN-TP-2 & $\mathrm{L}$ & Callahan & Tailings & $\begin{array}{l}\text { Fine-grained tailings from tailings pile near } \\
\text { edge of wetlands. }\end{array}$ & Light gray & 44.34306 & -68.80556 & $\begin{array}{c}\text { Jul-19- } \\
04\end{array}$ & Grab & $\begin{array}{l}\text { Dry sieved }<2 \\
\mathrm{~mm}\end{array}$ \\
\hline Blank & M & - & Blank & Blank & - & - & - & - & - & None \\
\hline $\begin{array}{l}\text { EMV-SED- } \\
\text { LOC05-Dup2 }\end{array}$ & $\mathrm{N}$ & Elizabeth & $\begin{array}{l}\text { Stream } \\
\text { sediment }\end{array}$ & $\begin{array}{l}\text { Copperas Brook below weir at sediment } \\
\text { basin outlet. Duplicate. }\end{array}$ & $\begin{array}{l}\text { Brownish } \\
\text { yellow }\end{array}$ & 43.82814 & -72.32739 & $\begin{array}{l}\text { June- } \\
05\end{array}$ & Grab & $\begin{array}{l}\text { Dry sieved }<2 \\
\mathrm{~mm}\end{array}$ \\
\hline TP1-S-unox & $\mathrm{O}$ & Elizabeth & Tailings & $\begin{array}{l}\text { Unoxidized sulfidic tailings from pile } 1 \\
\text { (TP1) near base of TP2. Collected at depth. }\end{array}$ & Very dark gray & 43.82332 & -72.32990 & $\begin{array}{l}\text { Jul-20- } \\
04\end{array}$ & Grab & Air-dried \\
\hline TP1-S-unox-Dup & $\mathrm{P}$ & Elizabeth & Tailings & $\begin{array}{l}\text { Unoxidized sulfidic tailings from TP1 near } \\
\text { base of TP2 collected at depth. Duplicate. }\end{array}$ & Very dark gray & 43.82332 & -72.32990 & $\begin{array}{c}\text { Jul-20- } \\
04\end{array}$ & Grab & Air-dried \\
\hline TP1-S-ox & Q & Elizabeth & Tailings & $\begin{array}{l}\text { Oxidized tailings from surface of TP1 near } \\
\text { base of TP2. }\end{array}$ & $\begin{array}{l}\text { Yellowish } \\
\text { brown }\end{array}$ & 43.82332 & -72.32990 & $\begin{array}{c}\text { Jul-20- } \\
04\end{array}$ & Grab & Air-dried \\
\hline 02ТР3А & $\mathrm{R}$ & Elizabeth & Mine waste & TP3 yellow waste pile below road. & Yellow & 43.82139 & -72.33611 & $\begin{array}{c}\text { Oct- } \\
10-02\end{array}$ & Composite & $\begin{array}{l}\text { Dry sieved }<2 \\
\mathrm{~mm}\end{array}$ \\
\hline 02ТР $3 \mathrm{C}$ & $\mathrm{S}$ & Elizabeth & Mine waste & TP3 roasted waste pile below road. & Yellowish red & 43.82056 & -72.33639 & $\begin{array}{l}\text { Oct- } \\
10-02\end{array}$ & Composite & $\begin{array}{l}\text { Dry sieved }<2 \\
\mathrm{~mm}\end{array}$ \\
\hline 02Ely2A & $\mathrm{T}$ & Ely Copper & Mine waste & Upper mine waste pile. & $\begin{array}{l}\text { Reddish } \\
\text { yellow }\end{array}$ & 43.92756 & -72.28572 & $\begin{array}{l}\text { Oct-8- } \\
02\end{array}$ & Composite & $\begin{array}{l}\text { Dry sieved }<2 \\
\mathrm{~mm}\end{array}$ \\
\hline 02Ely10A & $\mathrm{U}$ & Ely Copper & Mine waste & Roast beds. & Red & 43.92389 & -72.28556 & $\begin{array}{l}\text { Oct- } 8- \\
02\end{array}$ & Composite & $\begin{array}{l}\text { Dry sieved }<2 \\
\mathrm{~mm}\end{array}$ \\
\hline 04PKHL9 & $\mathrm{V}$ & $\begin{array}{l}\text { Pike Hill } \\
\text { Copper }\end{array}$ & Mine waste & $\begin{array}{l}\text { Partly burnt mine waste from above the } \\
\text { mine road. }\end{array}$ & $\begin{array}{l}\text { Yellowish } \\
\text { brown }\end{array}$ & 44.06258 & -72.30519 & $\begin{array}{l}\text { Oct- } \\
20-04\end{array}$ & Composite & $\begin{array}{l}\text { Dry sieved }<2 \\
\mathrm{~mm}\end{array}$ \\
\hline 04PKHL11 & W & $\begin{array}{l}\text { Pike Hill } \\
\text { Copper }\end{array}$ & Mine waste & $\begin{array}{l}\text { Large mine-waste dump below the mine } \\
\text { access road. }\end{array}$ & Yellow & 44.06353 & -72.30511 & $\begin{array}{l}\text { Oct- } \\
20-04\end{array}$ & Composite & $\begin{array}{l}\text { Dry sieved }<2 \\
\mathrm{~mm}\end{array}$ \\
\hline NZ-Newmont-A & $\mathrm{X}$ & Martha & Tailings & Fine-grained tailing from tailings pile. & Light gray & $\begin{array}{c}- \\
37.38592 \\
\end{array}$ & 175.84292 & $\begin{array}{l}\text { Dec- } \\
16-05\end{array}$ & Grab & Air-dried \\
\hline
\end{tabular}




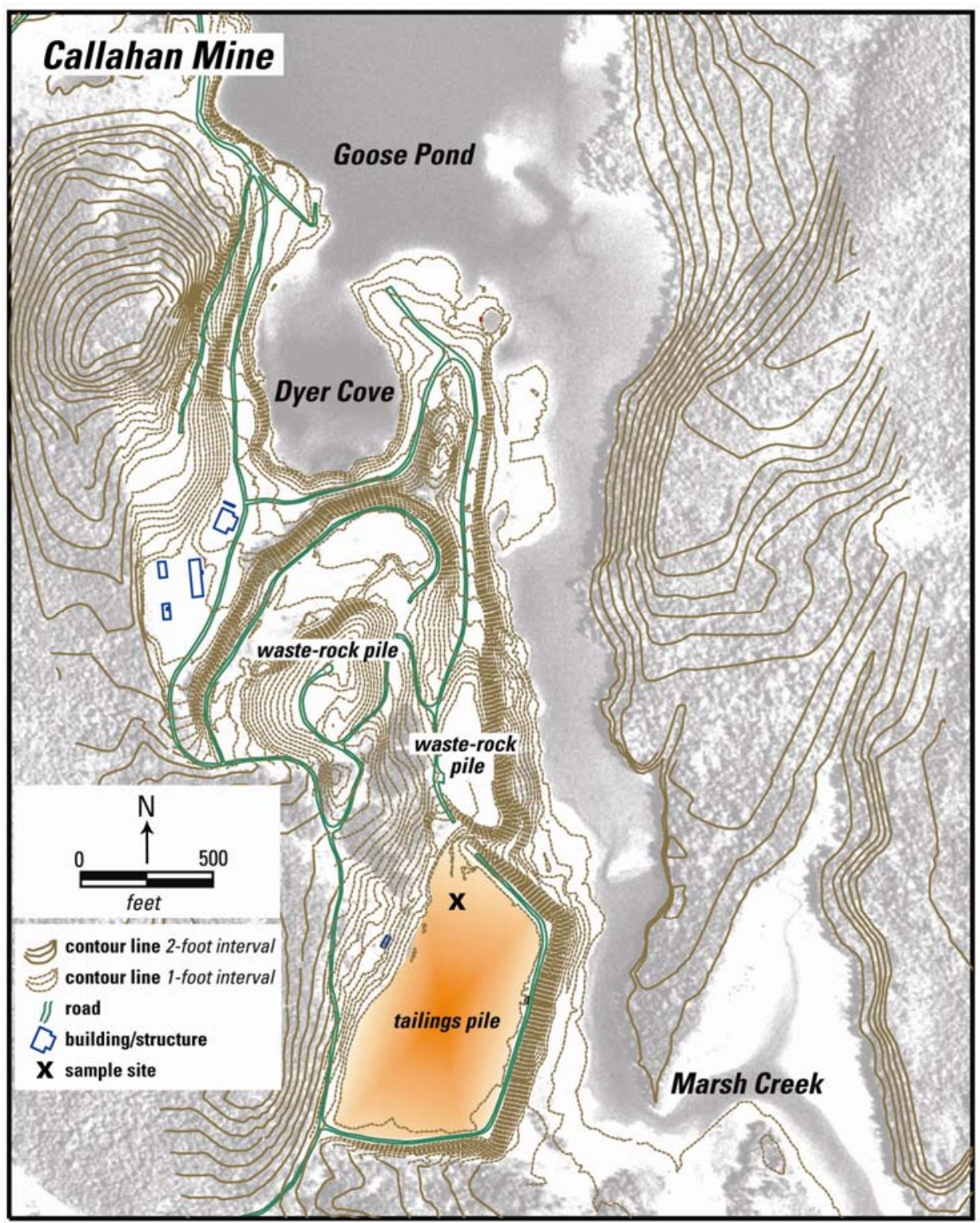

Figure 4. Location of sample from the Callahan Mine. Modified from MACTEC (2006).

\section{Methods}

\section{Mineralogy}

Minerals were identified by powder X-ray diffraction analysis (XRD). Diffraction patterns were collected using a Scintag X1 automated powder diffractometer equipped with a Peltier detector with $\mathrm{CuK} \alpha$ radiation. The XRD patterns were analyzed using Material Data Inc.'s JADE software and standard reference patterns. Relative amounts of phases were estimated using the Siroquant computer program, which utilizes the full XRD profile in a Rietveld refinement (Taylor and Clapp, 1992). The analytical uncertainty of the Siroquant results is approximately $\pm 5 \mathrm{wt}$. \%. The colors of the samples, given in table 1 , were determined using soil color charts (Munsell Soil Color Charts, 1994). 


\section{Sequential Extractions}

Seven-step sequential extractions were done on nineteen mine-waste and streamsediment samples, on three duplicates, and on two blanks (table 1). One blank was used for analytical calibration purposes (Extract ID 'A' in table 1). Samples were either grab or composites. Most composites consisted of a minimum of 30 sample increments sampled over a measured area divided into a stratified grid. One stream-sediment composite (Ely-SD-09) consisted of three increments from different depositional areas in the stream. Samples were airdried, sieved to $<2 \mathrm{~mm}$ ( or $<180 \mu \mathrm{m}$ for sample 1139830-SD, stream sediment from Pike Hill), and homogenized (table 1). After digestion by a mixture of $\mathrm{HCl}-\mathrm{HNO}_{3}-\mathrm{HClO}_{4}-\mathrm{HF}$, a split of the original untreated sample was analyzed by inductively coupled plasma-mass spectrometry (ICPMS) to determine the major- and trace-element composition (Briggs and Meier, 2002). A split of the original untreated sample was also analyzed by hydride-generation atomic absorption spectrometry (HG-AAS) to determine the concentration of Se after the sample was digested with a mixture of $\mathrm{HNO}_{3}-\mathrm{HF}-\mathrm{HClO}_{4}$ (Hageman and others, 2002). Residues remaining after extraction steps 5 and 6 were analyzed after digestion by ICP-MS and HG-AAS. Extraction solutes were analyzed by ICP-MS (Lamothe and others, 2002). The analyses were done in U.S. Geological Survey (USGS) laboratories in Denver, Colo. The accuracy of both methods was approximately $\pm 10 \%$.

The distribution of elements determined by sequential extractions were operationally defined by the reagents used, the reaction times, temperatures, and solid-to-extraction solution ratio for each step. No single reagent, time, and temperature combination could be applied to all sample types to recover a given phase; extractions were matrix-dependent. This extraction procedure also attempted to differentiate the amorphous (step 4) versus crystalline (step 5) ironoxide and iron-hydroxide phases. There is a gradation from amorphous to cryptocrystalline to crystalline iron-oxides and hydroxides; Hall and others (1996a) discussed the subtleties in differentiating among the phases depending on reagent strength. Additional complicating factors included the possibility that occluded grains might persist past their designated dissolution step or factors such as grain size, mineralogy, or solid solution may affect the reactivity of phases. The sequential extraction procedure used in this study is outlined below and illustrated in figure 5. The procedure was a combination of methods developed by Chao (1972), Chao and Sanzolone (1977; 1989), Chao and Zhou (1983), Chester and Hughes (1967), Hall and others (1996a, b), and Kulp and Pratt (2004). The hypothetically targeted species in each step are given in italics.

- $\quad$ Step 1: (soluble, adsorbed, and exchangeable fraction) Combine $1.0 \mathrm{~g}$ of sample with $25 \mathrm{~mL}$ $0.1 \mathrm{M} \mathrm{KH}_{2} \mathrm{PO}_{4}$, agitate for 2 hours at $25^{\circ} \mathrm{C}$. Centrifuge for 10 minutes $(15,000 \mathrm{rpm}$, Sorvall RC2-B refrigerated supercentrifuge), decant extract and dilute with deionized water (DIW) to $50 \mathrm{~mL}$. Add $500 \mu \mathrm{L}$ concentrated ultrapure $\mathrm{HNO}_{3}$. Analyze extract by ICP-MS (Extract 1 ).

- $\quad$ Step 2: (carbonates) Combine residue with $25 \mathrm{~mL} \mathrm{15 \%} \mathrm{acetic} \mathrm{acid,} \mathrm{agitate} \mathrm{for} 2$ hours, centrifuge, decant, fill to $50 \mathrm{~mL}$ volume with DIW. Analyze extract by ICP-MS (Extract 2).

- Step 3: (organic material) Combine residue with $25 \mathrm{~mL} 0.1 \mathrm{M}$ sodium pyrophosphate and agitate for 1 hour. Centrifuge and decant. Add another $25 \mathrm{~mL} 0.1 \mathrm{M}$ sodium pyrophosphate to residue, agitate for 1 hour, centrifuge, decant, add to first split and bring to $50 \mathrm{~mL}$ volume with DIW. Analyze extract by ICP-MS (Extract 3). 


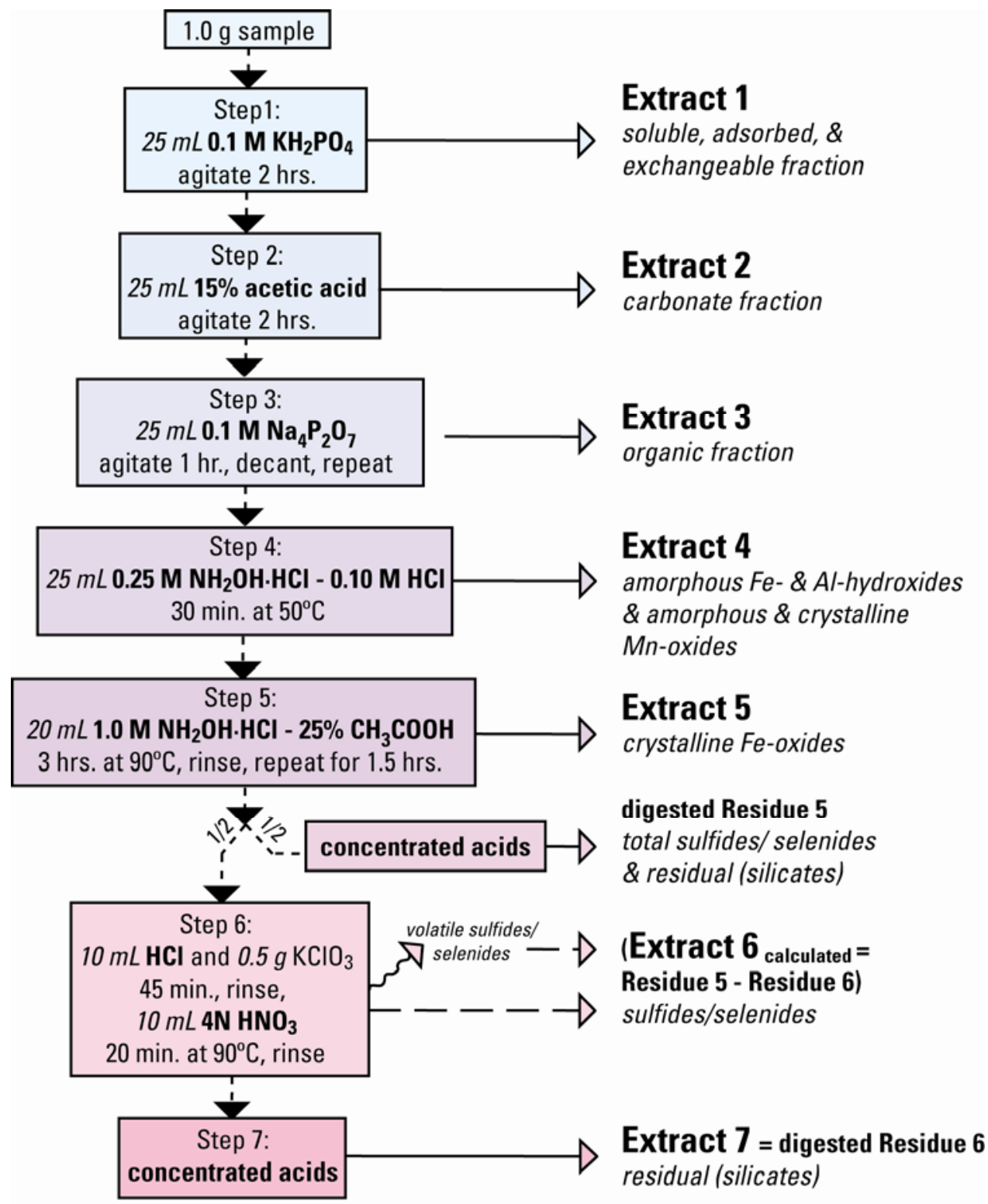

Figure 5. Schematic of sequential extraction procedure. After extract step 5 , half of sample was digested and analyzed by ICP-MS and HG-AAS and the other half was treated in step 6 . Because of the potential volatilization of sulfide and selenides in step 6, element concentrations in extract 6 were calculated from the difference between the concentration in the residue from step 5 and that in residue from step 6 .

- Step 4: (amorphous iron- and aluminum-hydroxides and amorphous and crystalline manganese-oxides) Mix residue with $25 \mathrm{~mL} 0.25 \mathrm{M} \mathrm{NH}_{2} \mathrm{OH} \cdot \mathrm{HCl}$ (hydroxylamine hydrochloride)- $0.10 \mathrm{M} \mathrm{HCl}$ for 30 minutes in a water bath at $50-54^{\circ} \mathrm{C}$. Stir occasionally. Centrifuge, decant and fill to $50 \mathrm{~mL}$ with DIW. Add $500 \mu \mathrm{L}$ concentrated ultrapure $\mathrm{HNO}_{3}$ and analyze by ICP-MS (Extract 4). 
- $\quad$ Step 5: (crystalline iron-oxides) Combine residue with $20 \mathrm{~mL} 1.0 \mathrm{M} \mathrm{NH}_{2} \mathrm{OH} \cdot \mathrm{HCl}$ in $25 \%$ acetic acid. Cap and shake. Place in boiling water $\left(\sim 90^{\circ} \mathrm{C}\right)$ bath for 3 hours uncapped, mix occasionally. Centrifuge and decant. Rinse residue with $10 \mathrm{~mL} \mathrm{25 \%}$ acetic acid, by handshaking and then centrifuge and decant into first split. Carry out a second leach with $20 \mathrm{~mL}$ $1.0 \mathrm{M} \mathrm{NH}_{2} \mathrm{OH} \cdot \mathrm{HCl}$ in $25 \%$ acetic acid but heat in boiling water bath for 1.5 hours. Mix occasionally. Centrifuge and decant into first split. Fill to $50 \mathrm{~mL}$ with DIW. Analyze extract by ICP-MS (Extract 5).

- $\quad$ Residue 5: (sulfides and selenides and residual material) Dry residue at approximately $100^{\circ} \mathrm{F}$ $\left(\sim 38^{\circ} \mathrm{C}\right)$ and then disaggregate to homogenize. Split residue in half. Digest half of sample with mixture of concentrated acids and analyze by ICP-MS and HG-AAS (Residue 5). Treat other half of residue in next step.

- $\quad$ Step 6: (sulfides and selenides- acid volatile phases volatilized; step may potentially attack surfaces, corners, or edges of silicate minerals) Add $0.5 \mathrm{~g}$ of $\mathrm{KClO}_{3}$ to residue and mix. Slowly add $10 \mathrm{~mL}$ concentrated $\mathrm{HCl}$ and mix. Let sit for 45 minutes with occasional gentle shaking. Add $10 \mathrm{~mL}$ of DIW, mix, centrifuge, and discard. To the residue, add $10 \mathrm{~mL} 4 \mathrm{~N}$ $\mathrm{HNO}_{3}$ and heat in boiling water bath for 20 minutes, centrifuge, and discard. Add $10 \mathrm{~mL}$ DIW, shake and centrifuge for 10 minutes, also discard. Because some sulfide and selenides may be volatilized, calculate step 6 fraction by subtracting element concentration in residue from step 5 from concentrations in residue from step 6 (Residue 5 - Residue 6).

- $\quad$ Step 7: (residual material) Dry residue at approximately $100^{\circ} \mathrm{F}\left(\sim 38^{\circ} \mathrm{C}\right)$. Digest sample with mixture of concentrated acids and analyze by ICP-MS and HG-AAS (Residue 6).

\section{Results}

\section{Mineralogy}

The quantitative mineralogy of the original unleached samples and residues after extraction steps 5 (residue 5) and 6 (residue 6) are given in Appendix 1. The relative amounts of phases in each sample in weight percent (wt. \%) were for the crystalline part of the sample only. The percentages of phases in the residues were normalized with respect to weight loss due to the dissolution of the various phases during the previous extraction steps. This measured weight loss in weight percent is given in Appendix 1. The detection limit for XRD was on the order of a few weight percent and therefore phases present in trace amounts were likely below reliable detection.

Most samples primarily were composed of silicates including quartz, feldspar (albite, anorthite, labradorite, microcline, orthoclase), hornblende, mica (muscovite), chlorite, and clay (kaolin, vermiculite, and vermiculite-type mixed layer clay). The mineralogy of the residues suggested that most of these silicates were resistant to the extraction reagents. The exceptions were several clay minerals such as vermiculite and the vermiculite-type mixed layer clay and, in some cases, hornblende. The vermiculite-type mixed layer clay had an intense broad peak at a spacing of approximately 11.5 to $12.0 \AA$, which was assigned to sepiolite by the XRD phase matching software. Sepiolite commonly forms in shallow seas and lakes and is not likely to be found in mine waste so this peak was likely from a hydrous altered biotite (Poppe and others, 2001). According to Rebertus and others (1986), biotite weathers to interstratified biotitevermiculite (hydrobiotite); thus this low angle peak may have been the result of varying degrees of biotite alteration. 
The only sample that contained significant carbonate was the tailings from the Callahan Mine (CLHN-TP-2) having nearly $20 \mathrm{wt}$. \% calcite. The second step using acetic acid aimed at dissolving carbonate minerals such as calcite $\left[\mathrm{CaCO}_{3}\right]$ and dolomite $\left[\mathrm{CaMg}\left(\mathrm{CO}_{3}\right)_{2}\right]$ (Kulp and Pratt, 2004). The residue remaining after step 5 did not contain detectable calcite; dissolution of calcite had taken place between steps 1 and 5 .

Step 4 of the extraction procedure targeted amorphous iron- and aluminum-hydroxides and amorphous and crystalline manganese-oxides (Chao, 1972; Chao and Zhou, 1983; Hall and others, 1996a). No crystalline manganese-oxide phases were detected by XRD. The crystalline $\mathrm{Fe}$-oxide and $\mathrm{Fe}$-hydroxysulfate minerals found in these samples included goethite [FeOOH], hematite $\left[\mathrm{Fe}_{2} \mathrm{O}_{3}\right]$, and jarosite $\left[\mathrm{K}_{2} \mathrm{Fe}_{6}\left(\mathrm{SO}_{4}\right)_{4}(\mathrm{OH})_{12}\right]$. Chester and Hughes (1967) reported the dissolution of crystalline iron-oxide minerals (goethite and hematite) using the reagents in step 5. Only partial dissolution of jarosite was expected based on a study by Filipek and Theobald (1981). Based on the mineralogy of residue 5, the reagents in steps 1 through 5 did not generally digest hematite and only partially digested goethite and jarosite (Appendix 1).

Several samples contained minor to trace amounts of sulfides. The reagents used in step 6 of the extraction procedure should have oxidized, possibly volatilized, and decomposed sulfides and selenides (Chao and Sanzolone, 1977). Nearly all of the estimated 15 wt. \% pyrrhotite in the unoxidized tailings from Elizabeth (TP1-S-unox) was digested after step 6. Pyrite was present in few weight percent for several samples and was broken down by reagents in step 6.

\section{Sequential Extractions}

The concentrations of elements in unleached samples are given in Appendix 2. The concentrations of elements in extracts from steps 1 through 5 and in residues after steps 5 and 6 are given in Appendix 3. The amounts of an element extracted from the solid were calculated from the extract concentration and solid-to-extraction solution ratio. The difference between the step 5 residue and the step 6 residue concentrations was the amount of an element extracted by step 6 solvents (selenide/sulfide fraction; see figure 5). Direct measurement of element concentrations in extract solution 6 was not used because some sulfides and selenides may have been volatilized by the acids utilized in step 6 .

The sum of the concentrations of an element leached from the solids in steps 1 through 5 plus the residue after step 5 (calculated total) should be equal to the original total element concentration of the solid (bulk total). The calculated total from the extractions generally correlated with the original unleached concentration for most of the major elements. Figure 6 shows these correlations for iron and calcium with the bulk total shown on the x-axis and the calculated total shown on the y-axis. As shown, many values plot within the $\pm 10 \%$ analytical uncertainty associated with the ICP-MS. The stream sediment from the Pike Hill Copper Mine is anomalous in figure 6 . For calcium, the sum of extractions 1 through 5 plus residue 5 falls within an acceptable range; but for nearly all samples, the concentration in residue 6 was higher than in the original sample (not shown). Therefore, the data for residue 6 for calcium were considered invalid and extract steps 6 and 7 were grouped together (sulfide/selenide and residual fractions). This was also applied to magnesium and manganese because a significant amount of samples contained higher concentrations of these elements in the final residue (residue 6) compared to the unleached sample. A reagent that contained sodium was used in step 3 so concentrations in extracts after this step were not examined. The concentrations of sodium in extracts 1 and 2 were at or below the detection limit for all samples except the tailings from the Martha Mine. Most aluminum was higher in the summed concentrations compared to the bulk 
concentration and for nearly all the samples the concentration in residue 6 was higher than in the original. This suggests one of the reagents may have been contaminated with aluminum.

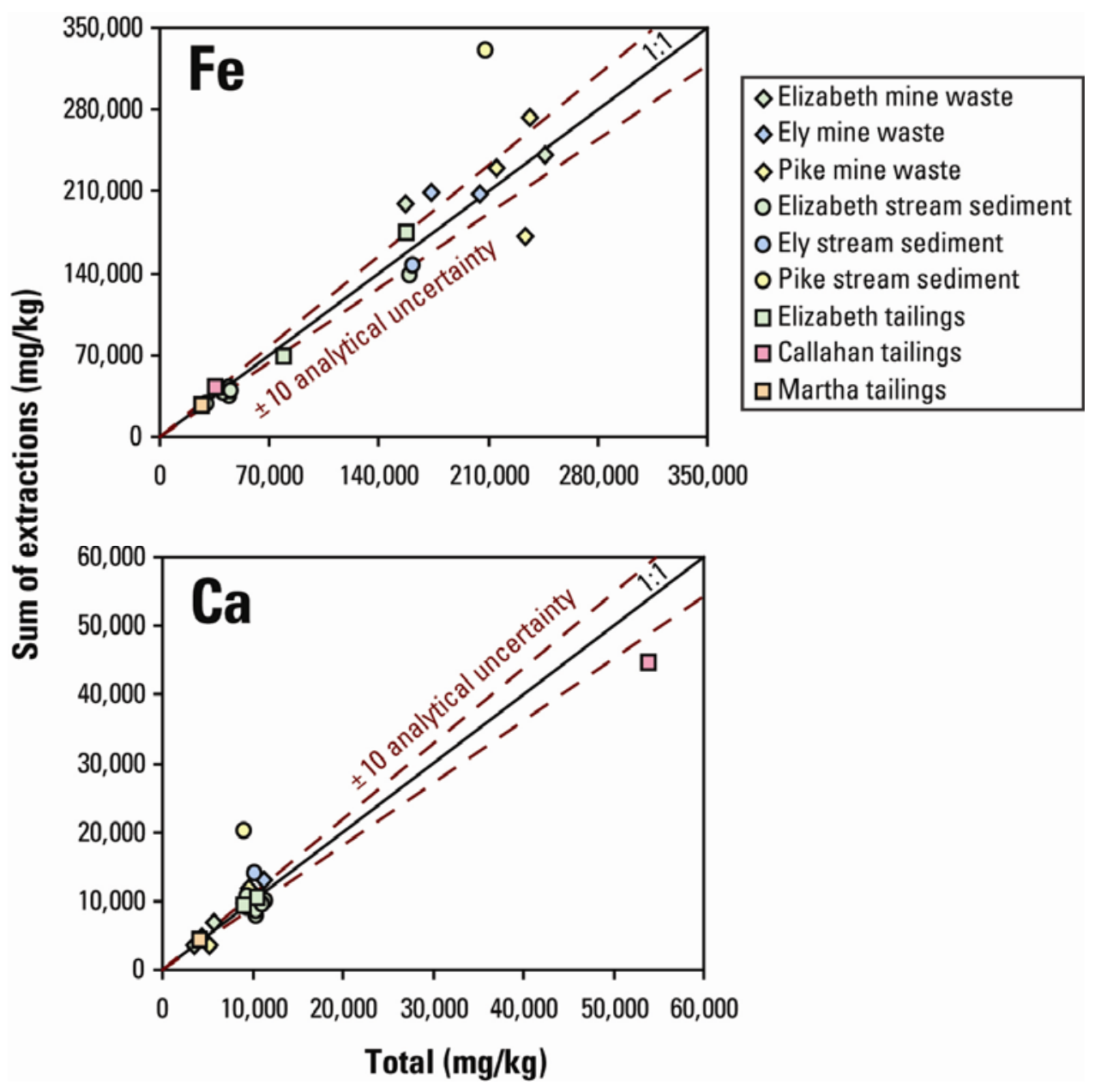

Figure 6. Calculated iron ( $\mathrm{Fe}$ ) and calcium ( $\mathrm{Ca}$ ) totals from extractions versus total from untreated samples. Calculated totals are the sum of an element in extracts 1,2,3,4, and 5 and in the residue after step 5. Zero was used for concentrations less than the detection limit. The black line represents a 1:1 correlation and the red dashed lines represent the analytical uncertainty of $\pm 10 \%$.

The calculated totals for trace elements generally correlated with concentrations in the unleached sample. In figure 7, the concentrations of arsenic, copper, selenium, and zinc for most samples fall within the $\pm 10 \%$ ICP-MS and HG-AAS analytical uncertainties. As with iron and calcium, the Pike Hill stream sediment is anomalous for copper and zinc. The results of the sequential extraction on other trace elements such as cadmium, cobalt, lead, and nickel also were reasonable because calculated totals generally correlated with the original bulk concentrations. Based on these comparisons, the validity of the data from the extractions was assessed. For most elements, the extraction results were within the acceptable range of error. Future reports will interpret the results of the sequential extractions in more detail. 


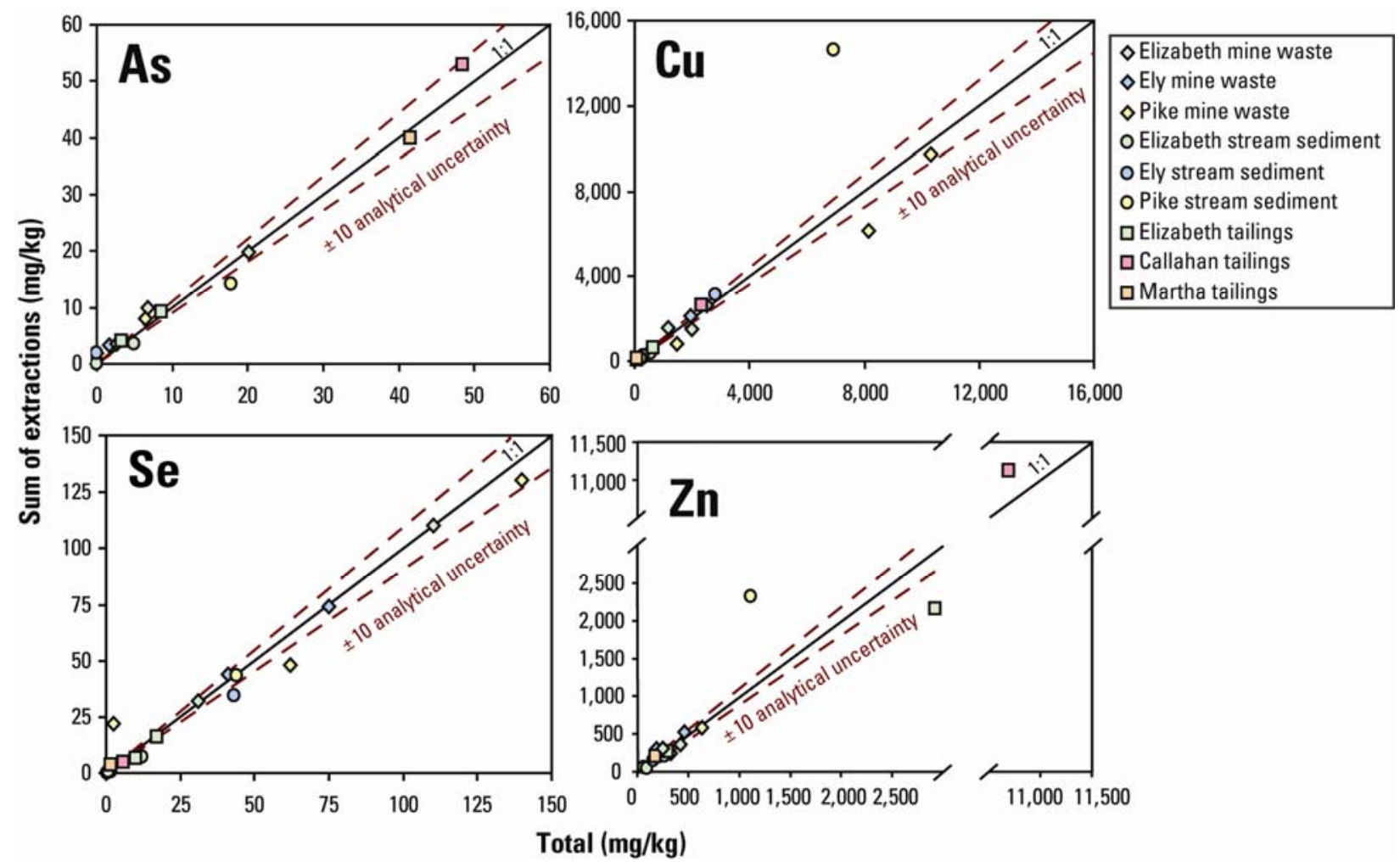

Figure 7. Calculated arsenic (As), copper (Cu), selenium (Se), and zinc ( $\mathrm{Zn}$ ) totals from extractions versus total from untreated samples. Calculated totals are the sum of an element in extracts 1,2, 3,4 , and 5 and in the residue after step 5 . Zero was used for concentrations less than the detection limit. The black line represents a 1:1 correlation and the red dashed lines represent the analytical uncertainty of $\pm 10 \%$.

\section{Acknowledgments}

The authors would like to thank Ed Hathaway, U.S. Environmental Protection Agency, and Scott Acone, U.S. Army Corps of Engineers, for facilitating this project. The study was funded by the U.S. Environmental Protection Agency as part of the remedial investigation that is being implemented through an interagency agreement with the U.S. Army Corps of Engineers and by the Mineral Resources Program of the U.S. Geological Survey. The authors are grateful to Jeff Mauk from The University of Auckland for providing the sample from the Martha Mine. We also thank Jason Clere, Kate McDonald, and Frederik Schuele from the URS Corporation for providing stream-sediment samples from the Elizabeth and Ely mines. Jane Hammarstrom, John Jackson, and Tim Muzik from the U.S. Geological Survey helped collect and characterize several samples from the mines in Vermont. The manuscript benefited from reviews by Avery Drake, Ed Hathaway, and Jane Hammarstrom. 


\section{References Cited}

Bouley, B.A., and Hodder, R.W., 1984, Strata-bound massive sulfide deposits in SilurianDevonian volcanic rocks at Harborside, Maine: Economic Geology, v. 79, p. 1693-1702.

Briggs, P.H. and Meier., A.L., 2002, The determination of forty-two elements in geological materials by inductively coupled plasma- mass spectrometry, in Taggart, J.E., Jr., eds., Analytical methods for chemical analysis of geologic and other materials: U.S. Geological Survey Open-File Report 02-0223, p. I1-I14, http://pubs.usgs.gov/of/2002/ofr-02-0223/.

Castendyk, D.N., Mauk, J.L, and Webster, J.G., 2005, A mineral quantification method for wall rocks at open pit mines, and application to the Martha Au-Ag mine, Waihi, New Zealand: Applied Geochemistry, v. 20, p. 135-156.

Chao, T.T., 1972, Selective dissolution of manganese oxides from soils and sediments with acidified hydroxylamine hydrochloride: Soil Science Society of America Proceedings, v. 36, p. 764-768.

Chao, T.T., and Sanzolone, R.F., 1977, Chemical dissolution of sulfide minerals: Journal of Research of the U.S. Geological Survey, v. 5, no. 4, p. 409-412.

Chao, T.T., and Sanzolone, R.F., 1989, Fractionation of soil selenium by sequential partial dissolution: Soil Science Society of America Journal, v. 53, p. 385-392.

Chao, T.T., and Zhou, L., 1983, Extraction techniques for selective dissolution of amorphous iron oxides from soils and sediments: Soil Science Society of America Journal, v. 47, p. 225 232.

Chester, R. and Hughes, H.J., 1967, A chemical technique for the separation of ferro-manganese minerals, carbonate minerals and adsorbed trace elements from pelagic sediments: Chemical Geology, v. 2, p. 249-262.

Filipek, L.H., and Theobald, P.K., Jr., 1981, Sequential extraction techniques applied to a porphyry copper deposit in the Basin and Range Province: Journal of Geochemical Exploration, v. 14, p. 155-174.

Hageman, P.L., Brown, Z.A., and Welsch, E., 2002, Arsenic and selenium by flow injection or continuous flow-hydride generation-atomic absorption spectrophotometry, in Taggart, J.E., Jr., ed., Analytical methods for chemical analysis of geologic and other materials: U.S. Geological Survey Open-File Report 02-0223, http://pubs.usgs.gov/of/2002/ofr-02-0223/.

Hall, G.E.M., Vaive, J.E., Beer, R., and Hoashi, M., 1996a, Selective leaches revisited, with emphasis on the amorphous Fe oxyhydroxide phase extraction: Journal of Geochemical Exploration, v. 56, p. 59-78.

Hall, G.E.M., Vaive, J.E., and MacLaurin, A.I., 1996b, Analytical aspects of the application of sodium pyrophosphate reagent in the specific extraction of the labile organic component of humus and soils: Journal of Geochemical Exploration, v. 56, p. 23-36. 
Kulp, T.R., and Pratt, L.M., 2004, Speciation and weathering of selenium in Upper Cretaceous chalk and shale from South Dakota and Wyoming, USA: Geochimica et Cosmochimica Acta, v. 68 , p. $3687-3701$.

Lamothe, P.J., Meier, A.L., and Wilson, S., 2002, The determination of forty-four elements in aqueous samples in inductively coupled plasma-mass spectrometry, in Taggart, J.E., Jr., eds., Analytical methods for chemical analysis of geologic and other materials: U.S. Geological Survey Open-File Report 02-0223, http://pubs.usgs.gov/of/2002/ofr-02-0223/.

MACTEC Engineering and Consulting, Inc. (MACTEC), 2006, Final work plan for Remedial Investigation/Feasiblity Study, Callahan Mining Superfund Site, Brooksville, Maine: unpublished report prepared for Maine Department of Transportation, MACTEC Project 3612052031 .

Munsell Soil Color Charts, 1994, Munsell Color, Gretag-Macbeth, New Windsor, NY, 1994 revised edition.

Piatak, N.M., Hammarstrom, J.M., Seal, R.R., II, Briggs, P.H., Meier, A.L., Muzik, T.L., and Jackson, J.C., 2004, Geochemical characterization of mine waste at the Ely copper mine Superfund site, Orange County, Vermont: U.S. Geological Survey Open-File Report 20041248, http://pubs.usgs.gov/of/2004/1248/.

Piatak, N.M., Seal, R.R., II, Sanzolone, R.F., Lamothe, P.J., and Brown, Z.A., 2006a, Distribution of selenium in mine waste and stream sediments associated with abandoned basemetal mines based on sequential extraction experiments: Geological Society of America, Abstracts with Programs, v. 38, no. 7, p. 424.

Piatak, N.M., Seal, R.R., II, Sanzolone, R.F., Lamothe, P.J., and Brown, Z.A., 2006b, Preliminary results of sequential extraction experiments for selenium on mine waste and stream sediments from Vermont, Maine, and New Zealand: U.S. Geological Survey Open-File Report 2006-1184, http://pubs.usgs.gov/of/2006/1184/of2006-1184.pdf.

Piatak, N.M., Seal, R.R., II, Hammarstrom, J.M., Kiah, R.G., Deacon, J.R., Adams, M., Anthony, M.W., Briggs, P.H., and Jackson, J.C., 2006c, Geochemical characterization of mine waste, mine drainage, and stream sediments at the Pike Hill Copper Mine Superfund Site, Orange County, Vermont: U.S. Geological Survey Scientific Investigations Report 2006-5303.

Poppe, L.J., Paskevich, V.F., Hathaway, J.C., Blackwood, D.S., 2001, A laboratory manual for X-ray powder diffraction: U.S. Geological Survey Open-File Report 01-041, http://pubs.usgs.gov/of/2001/of01-041/index.htm.

Rebertus, R.A., Weed, S.B., and Buol, S.W., 1986, Transformations of biotite and kaolinite during saprolite-soil weathering: Soil Science of America Journal, v. 50, p. 810-819.

Slack, J.F., Offield, T.W., Woodruff, L.G., and Shanks, W.C., III, 2001, Geology and geochemistry of Besshi-type massive sulfide deposits of the Vermont copper belt: Society of Economic Geologists Guidebook Series, v. 35, p. 193-211. 
Taylor, J.C., and Clapp, R.A., 1992, New features and advanced applications of Siroquant: A personal computer XRD full profile quantitative analysis software package: Advances in X-ray Analysis, v. 35, p. 49-55.

White, W.S., and Eric, J.H., 1944, Preliminary report; geology of Orange County copper district, Vermont: U.S. Geological Survey Open-File Report 44-0019. 
Appendix 1. Estimates of mineral abundances in original unleached samples and in residues after extraction steps 5 and 6 normalized with respect to measured weight loss. Values given in weight percent.

\begin{tabular}{|c|c|c|c|c|c|c|c|c|c|c|c|c|c|}
\hline Sample ID & $\begin{array}{l}\text { EMV-SED- } \\
\text { LOC05 }\end{array}$ & $\begin{array}{l}\text { EMV-SED- } \\
\text { LOC05 }\end{array}$ & $\begin{array}{l}\text { EMV-SED- } \\
\text { LOC05 }\end{array}$ & $\begin{array}{l}\text { EMV-SED- } \\
\text { LOC05 }\end{array}$ & $\begin{array}{l}\text { EMV-SED- } \\
\text { LOC05 }\end{array}$ & $\begin{array}{l}\text { EMV-SED- } \\
\text { LOC05 }\end{array}$ & $\begin{array}{l}\text { EMV-SED- } \\
\text { LOC06 }\end{array}$ & $\begin{array}{l}\text { EMV-SED- } \\
\text { LOC06 }\end{array}$ & $\begin{array}{l}\text { EMV-SED- } \\
\text { LOC06 }\end{array}$ & $\begin{array}{l}\text { EMV- } \\
\text { SED-04 }\end{array}$ & $\begin{array}{l}\text { EMV- } \\
\text { SED-04 }\end{array}$ & $\begin{array}{l}\text { EMV- } \\
\text { SED-04 }\end{array}$ & $\begin{array}{l}\text { EMV- } \\
\text { SED-06 }\end{array}$ \\
\hline $\begin{array}{l}\text { Extract ID } \\
\text { Sample split }\end{array}$ & $\begin{array}{c}\mathrm{B}, \mathrm{C}, \mathrm{N} \\
\text { original }\end{array}$ & $\begin{array}{c}\text { B } \\
\text { residue } 5\end{array}$ & $\begin{array}{c}\text { B } \\
\text { residue } 6\end{array}$ & $\begin{array}{c}\text { B, C, N } \\
\text { original }\end{array}$ & $\begin{array}{c}\text { C } \\
\text { residue } 5\end{array}$ & $\begin{array}{c}\text { C } \\
\text { residue } 6\end{array}$ & $\begin{array}{c}\text { D } \\
\text { original }\end{array}$ & $\begin{array}{c}\text { D } \\
\text { residue } 5\end{array}$ & $\begin{array}{c}\text { D } \\
\text { residue } 6\end{array}$ & $\begin{array}{c}E \\
\text { original }\end{array}$ & $\begin{array}{c}\text { E } \\
\text { residue } 5\end{array}$ & $\begin{array}{c}\text { E } \\
\text { residue } 6\end{array}$ & $\begin{array}{c}\mathbf{F} \\
\text { original }\end{array}$ \\
\hline Weight loss & - & 19.0 & 37.6 & - & 19.6 & 37.9 & - & 7.2 & 16.3 & - & 7.8 & 16.9 & - \\
\hline Albite & 13.4 & 12.6 & 12.2 & 13.4 & - & 10.5 & 7.7 & 9.5 & 10.5 & 9.4 & 9.3 & 7.9 & 8.1 \\
\hline Anorthite & 1.6 & 0.5 & 5.2 & 1.6 & - & 9.3 & 5.8 & 0.0 & 0.0 & 5.1 & 4.0 & 3.5 & 4.0 \\
\hline Augite & - & - & - & - & - & - & - & - & - & - & - & - & - \\
\hline Calcite & - & - & - & - & - & - & - & - & - & - & - & - & - \\
\hline Chalcopyrite & - & - & - & - & - & - & - & - & - & - & - & - & - \\
\hline Chlorite & 4.1 & 5.5 & 2.4 & 4.1 & - & 3.1 & 2.4 & 3.7 & 1.8 & 2.9 & 0.2 & 2.1 & 4.3 \\
\hline Copiapite & - & - & - & - & - & - & - & - & - & - & - & - & - \\
\hline Goethite & 5.8 & 1.9 & 1.2 & 5.8 & - & 0.6 & - & - & - & - & - & - & - \\
\hline Gypsum & - & - & - & - & - & - & - & - & - & - & - & - & - \\
\hline Hematite & - & - & - & - & - & - & - & - & - & - & - & - & - \\
\hline Hornblende & 9.4 & 0.0 & 2.7 & 9.4 & - & 2.4 & 0.9 & 1.9 & 0.4 & 3.1 & 0.8 & 1.5 & 3.8 \\
\hline Jarosite & 8.6 & 2.7 & 1.2 & 8.6 & - & 1.0 & - & - & - & - & - & - & - \\
\hline Kaolin & 0.0 & - & - & 0.0 & - & - & 0.3 & 0.0 & 0.1 & 0.0 & 0.6 & 0.1 & 0.0 \\
\hline Labradorite & - & - & - & - & - & - & - & - & - & - & - & - & - \\
\hline Lepidocrocite & 0.0 & - & - & 0.0 & - & - & - & - & - & - & - & - & - \\
\hline Melanterite & - & - & - & - & - & - & - & - & - & - & - & - & - \\
\hline Microcline & - & - & - & - & - & - & - & - & - & - & - & - & - \\
\hline Muscovite & 3.9 & 1.6 & 7.7 & 3.9 & - & 7.7 & 3.6 & 3.8 & 2.9 & 3.2 & 4.5 & 3.5 & 4.6 \\
\hline Orthoclase & - & - & - & - & - & - & - & - & - & - & - & - & - \\
\hline Pyrite & - & - & - & - & - & - & - & - & - & - & - & - & - \\
\hline Pyrrhotite & - & - & - & - & - & - & - & - & - & - & - & - & - \\
\hline Quartz & 50.3 & 54.7 & 29.6 & 50.3 & - & 25.7 & 76.4 & 73.8 & 68.0 & 69.2 & 72.7 & 64.5 & 73.2 \\
\hline Rozenite & - & - & - & - & - & - & - & - & - & - & - & - & - \\
\hline Rutile & - & - & - & - & - & - & - & - & - & - & - & - & - \\
\hline Sepiolite $^{1}$ & 0.0 & - & - & 0.0 & - & - & 0.4 & 0.0 & 0.0 & 0.4 & 0.0 & 0.1 & 0.3 \\
\hline Sphalerite & - & - & - & - & - & - & - & - & - & - & - & - & - \\
\hline Talc & 1.9 & 1.5 & 0.0 & 1.9 & - & 1.7 & - & - & - & - & - & - & - \\
\hline Vermiculite & 1.1 & 0.0 & 0.0 & 1.1 & - & 0.0 & 2.6 & 0.0 & 0.0 & 6.7 & 0.1 & 0.0 & 1.7 \\
\hline Chi-square $^{2}$ & 4.2 & 3.6 & 3.5 & 4.2 & - & 4.1 & 4.3 & 3.7 & 4.2 & 6.0 & 3.8 & 3.8 & 5.1 \\
\hline
\end{tabular}


Appendix 1. Estimates of mineral abundances in original unleached samples and in residues after extraction steps 5 and 6 normalized with respect to measured weight loss. Values given in weight percent.-Continued

\begin{tabular}{|c|c|c|c|c|c|c|c|c|c|c|c|c|}
\hline Sample ID & $\begin{array}{c}\text { EMV-SED- } \\
06\end{array}$ & $\begin{array}{c}\text { EMV-SED- } \\
06\end{array}$ & $\begin{array}{c}\text { EMV-SED- } \\
701\end{array}$ & $\begin{array}{c}\text { EMV-SED- } \\
701\end{array}$ & $\begin{array}{c}\text { EMV-SED- } \\
701\end{array}$ & $\begin{array}{c}\text { EMV-SED- } \\
702\end{array}$ & $\begin{array}{c}\text { EMV-SED- } \\
702\end{array}$ & $\begin{array}{c}\text { EMV-SED- } \\
702\end{array}$ & Ely-SD-09 & Ely-SD-09 & Ely-SD-09 & $\begin{array}{l}\text { 1139830- } \\
\text { SD }\end{array}$ \\
\hline $\begin{array}{l}\text { Extract ID } \\
\text { Sample split }\end{array}$ & $\begin{array}{c}\text { F } \\
\text { residue } 5 \\
\end{array}$ & $\begin{array}{c}\mathbf{F} \\
\text { residue } 6 \\
\end{array}$ & $\begin{array}{c}\text { G } \\
\text { original }\end{array}$ & $\begin{array}{c}\text { G } \\
\text { residue } 5\end{array}$ & $\begin{array}{c}\text { G } \\
\text { residue } 6\end{array}$ & $\begin{array}{c}\text { H } \\
\text { original }\end{array}$ & $\begin{array}{c}\text { H } \\
\text { residue } 5\end{array}$ & $\begin{array}{c}\text { H } \\
\text { residue } 6\end{array}$ & $\begin{array}{c}\text { I } \\
\text { original }\end{array}$ & $\begin{array}{c}\text { I } \\
\text { residue } 5\end{array}$ & $\begin{array}{c}\text { I } \\
\text { residue } 6\end{array}$ & $\begin{array}{c}\mathbf{J} \\
\text { original }\end{array}$ \\
\hline Weight loss & 7.9 & 16.1 & - & 7.5 & 12.7 & - & 6.6 & 13.8 & - & 17.3 & 32.1 & - \\
\hline Albite & 6.9 & 7.0 & 7.3 & 14.2 & 10.9 & 9.7 & 10.3 & 6.3 & 16.7 & 16.7 & 13.0 & 4.4 \\
\hline Anorthite & 2.3 & 3.3 & 4.1 & 1.7 & 0.0 & 4.4 & 0.8 & 2.5 & 6.5 & 0.4 & 5.6 & 7.7 \\
\hline Augite & - & - & - & - & - & - & - & - & - & - & - & - \\
\hline Chalcopyrite & - & - & - & - & - & - & - & - & - & - & - & 1.6 \\
\hline Chlorite & 6.6 & 4.5 & 2.5 & 3.6 & 3.6 & 5.0 & 9.0 & 2.6 & 4.8 & 3.7 & 3.4 & 0.0 \\
\hline Copiapite & - & - & - & - & - & - & - & - & - & - & - & - \\
\hline Goethite & - & - & - & - & - & - & - & - & 4.7 & 5.6 & 0.6 & 19.7 \\
\hline Gypsum & - & - & - & - & - & - & - & - & - & - & - & - \\
\hline Hematite & - & - & - & - & - & - & - & - & - & - & - & - \\
\hline Hornblende & 0.9 & 0.0 & 2.4 & 0.0 & 0.0 & 2.2 & 2.1 & 1.6 & 5.5 & 0.0 & 0.0 & 1.1 \\
\hline Jarosite & - & - & - & - & - & - & - & - & 4.4 & 0.6 & 0.8 & 2.6 \\
\hline Labradorite & - & - & - & - & - & - & - & - & - & - & - & - \\
\hline Lepidocrocite & - & - & - & - & - & - & - & - & - & - & - & - \\
\hline Melanterite & - & - & - & - & - & - & - & - & - & - & - & - \\
\hline Microcline & - & - & - & - & - & - & - & - & - & - & - & - \\
\hline Muscovite & 6.4 & 5.5 & 5.3 & 3.1 & 1.9 & 6.3 & 3.0 & 3.8 & 10.9 & 13.1 & 10.7 & 7.9 \\
\hline Orthoclase & - & - & - & - & - & - & - & - & - & - & - & - \\
\hline Pyrite & - & - & - & - & - & - & - & - & - & - & - & - \\
\hline Pyrrhotite & - & - & - & - & - & - & - & - & - & - & - & - \\
\hline Quartz & 68.9 & 63.6 & 76.2 & 69.9 & 70.7 & 68.1 & 68.2 & 69.3 & 43.4 & 42.4 & 33.8 & 49.7 \\
\hline Rozenite & - & - & - & - & - & - & - & - & - & - & - & - \\
\hline Rutile & - & - & - & - & - & - & - & - & - & - & - & 0.0 \\
\hline Sepiolite & 0.0 & 0.0 & 1.3 & 0.0 & 0.0 & 0.8 & 0.1 & 0.0 & 3.0 & 0.1 & 0.1 & - \\
\hline Sphalerite & - & - & - & - & - & - & - & - & - & - & - & - \\
\hline Talc & - & - & - & - & - & - & - & - & - & - & - & - \\
\hline Vermiculite & 0.0 & 0.0 & 0.7 & 0.0 & 0.0 & 3.4 & 0.0 & 0.0 & - & 0.0 & 0.0 & 3.5 \\
\hline Chi-square $^{2}$ & 4.2 & 4.2 & 4.6 & 4.3 & 3.8 & 5.1 & 4.3 & 3.6 & 4.3 & 3.9 & 4.8 & 4.2 \\
\hline
\end{tabular}


Appendix 1. Estimates of mineral abundances in original unleached samples and in residues after extraction steps 5 and 6 normalized with respect to measured weight loss. Values given in weight percent.-Continued

\begin{tabular}{|c|c|c|c|c|c|c|c|c|c|c|c|c|c|}
\hline Sample ID & $\begin{array}{c}1139830- \\
\text { SD }\end{array}$ & $\begin{array}{l}\text { 1139830- } \\
\text { SD }\end{array}$ & 04Smith3 & 04Smith3 & 04Smith3 & $\begin{array}{c}\text { CLHN-TP- } \\
2\end{array}$ & $\begin{array}{c}\text { CLHN-TP- } \\
2\end{array}$ & $\begin{array}{c}\text { CLHN-TP- } \\
2\end{array}$ & $\begin{array}{l}\text { EMV-SED- } \\
\text { LOC05 }\end{array}$ & $\begin{array}{l}\text { EMV-SED- } \\
\text { LOC05 }\end{array}$ & $\begin{array}{l}\text { EMV-SED- } \\
\text { LOC05 }\end{array}$ & $\begin{array}{l}\text { TP1-S- } \\
\text { unox }\end{array}$ & $\begin{array}{l}\text { TP1-S- } \\
\text { unox }\end{array}$ \\
\hline $\begin{array}{l}\text { Extract ID } \\
\text { Sample split }\end{array}$ & $\begin{array}{c}\mathbf{J} \\
\text { residue } 5\end{array}$ & $\begin{array}{c}\mathbf{J} \\
\text { residue } 6 \\
\end{array}$ & $\begin{array}{c}\mathrm{K} \\
\text { original }\end{array}$ & $\begin{array}{c}\mathrm{K} \\
\text { residue } 5 \\
\end{array}$ & $\begin{array}{c}\mathrm{K} \\
\text { residue } 6 \\
\end{array}$ & $\begin{array}{c}\mathrm{L} \\
\text { original }\end{array}$ & $\begin{array}{c}\text { L } \\
\text { residue } 5 \\
\end{array}$ & $\begin{array}{c}\mathrm{L} \\
\text { residue } 6 \\
\end{array}$ & $\begin{array}{c}\mathrm{B}, \mathrm{C}, \mathrm{N} \\
\text { original }\end{array}$ & $\begin{array}{c}\mathbf{N} \\
\text { residue } 5 \\
\end{array}$ & $\begin{array}{c}\mathbf{N} \\
\text { residue } 6 \\
\end{array}$ & $\begin{array}{c}\mathbf{O}, \mathbf{P} \\
\text { original }\end{array}$ & $\begin{array}{c}0 \\
\text { residue } 5\end{array}$ \\
\hline Weight loss & 19.6 & 41.4 & - & 28.5 & 55.6 & - & 17.0 & 27.7 & - & 16.0 & 35.3 & - & 8.1 \\
\hline Albite & 5.9 & 5.8 & 8.6 & 2.9 & 2.8 & - & - & - & 13.4 & 12.6 & 13.7 & 8.3 & 15.3 \\
\hline Anorthite & 2.8 & 6.7 & 0.0 & - & - & - & - & - & 1.6 & 0.8 & 1.6 & 11.8 & 7.7 \\
\hline Augite & - & - & - & - & - & - & - & - & - & - & - & - & - \\
\hline Calcite & 0.0 & - & 0.0 & - & - & 19.4 & 0.0 & 0.0 & - & - & - & - & - \\
\hline Chalcopyrite & 1.0 & 0.0 & 0.1 & - & - & - & - & - & - & - & - & - & - \\
\hline Chlorite & 0.0 & - & 4.9 & 8.7 & 7.3 & 27.2 & 24.4 & 22.3 & 4.1 & 3.4 & 4.4 & 4.3 & 2.1 \\
\hline Copiapite & - & - & 0.4 & - & - & - & - & - & - & - & - & - & - \\
\hline Goethite & 6.9 & 4.2 & 12.6 & 8.9 & 0.8 & - & - & - & 5.8 & 2.8 & 1.2 & - & - \\
\hline Gypsum & - & - & 0.3 & - & - & - & - & - & - & - & - & - & - \\
\hline Hematite & - & - & - & - & - & - & - & - & - & - & - & - & - \\
\hline Hornblende & 0.0 & 3.2 & 0.0 & - & - & - & - & - & 9.4 & 0.0 & 0.5 & - & - \\
\hline Jarosite & 0.0 & - & 12.5 & 1.4 & 0.7 & - & - & - & 8.6 & 2.9 & 1.6 & - & - \\
\hline Kaolin & 1.1 & 0.6 & 1.6 & 0.8 & 0.5 & - & - & - & 0.0 & - & - & - & - \\
\hline Labradorite & - & - & 9.9 & 12.2 & 13.7 & - & - & - & - & - & - & - & - \\
\hline Lepidocrocite & - & - & 1.0 & 1.2 & 0.3 & - & - & - & 0.0 & - & - & - & - \\
\hline Melanterite & - & - & 0.8 & - & - & - & - & - & - & - & - & - & - \\
\hline Microcline & - & - & - & - & - & - & - & - & - & - & - & - & - \\
\hline Muscovite & 10.6 & 5.9 & 7.4 & 11.6 & 5.6 & 7.0 & 12.1 & 9.3 & 3.9 & 3.2 & 5.8 & 22.3 & 17.4 \\
\hline Orthoclase & - & - & - & - & - & - & - & - & - & - & - & - & - \\
\hline Pyrite & - & - & 1.4 & 1.5 & 0.0 & 3.0 & 2.9 & 0.1 & - & - & - & 5.5 & 7.5 \\
\hline Pyrrhotite & - & - & 0.0 & - & - & - & - & - & - & - & - & 14.6 & 12.2 \\
\hline Quartz & 52.1 & 32.0 & 29.5 & 21.3 & 11.5 & 18.3 & 19.0 & 15.3 & 50.3 & 56.9 & 33.8 & 32.9 & 29.4 \\
\hline Rozenite & - & - & 0.0 & - & - & - & - & - & - & - & - & - & - \\
\hline Rutile & - & - & 1.0 & 0.8 & 1.1 & - & - & - & - & - & - & - & - \\
\hline Sepiolite & - & - & 7.6 & 0.1 & 0.0 & - & - & - & 0.0 & - & - & - & - \\
\hline Sphalerite & - & - & 0.1 & - & - & 2.3 & 2.6 & 2.2 & - & - & - & 0.3 & 0.2 \\
\hline Talc & - & - & - & - & - & 22.8 & 22.0 & 23.0 & 1.9 & 1.4 & 2.2 & 0.0 & - \\
\hline Vermiculite & 0.0 & 0.0 & - & - & - & - & - & - & 1.1 & 0.0 & 0.0 & - & - \\
\hline Chi-square $^{2}$ & 3.1 & 3.7 & 4.2 & 3.3 & 3.0 & 5.2 & 5.4 & 6.7 & 4.2 & 3.4 & 3.6 & 5.0 & 3.1 \\
\hline
\end{tabular}


Appendix 1. Estimates of mineral abundances in original unleached samples and in residues after extraction steps 5 and 6 normalized with respect to measured weight loss. Values given in weight percent.-Continued

\begin{tabular}{|c|c|c|c|c|c|c|c|c|c|c|c|c|c|c|}
\hline Sample ID & $\begin{array}{l}\text { TP1-S- } \\
\text { unox }\end{array}$ & $\begin{array}{l}\text { TP1-S- } \\
\text { unox }\end{array}$ & $\begin{array}{l}\text { TP1-S- } \\
\text { unox }\end{array}$ & $\begin{array}{l}\text { TP1-S- } \\
\text { unox }\end{array}$ & TP1-S-ox & TP1-S-ox & TP1-S-ox & 02TP3A & 02TP3A & 02TP3A & 02TP3C & 02TP3C & 02TP3C & 02Ely2A \\
\hline $\begin{array}{l}\text { Extract ID } \\
\text { Sample split }\end{array}$ & $\begin{array}{c}0 \\
\text { residue } 6 \\
\end{array}$ & $\begin{array}{c}0, P \\
\text { original }\end{array}$ & $\begin{array}{c}\mathrm{P} \\
\text { residue } 5 \\
\end{array}$ & $\begin{array}{c}\mathbf{P} \\
\text { residue } 6 \\
\end{array}$ & $\begin{array}{c}0 \\
\text { original }\end{array}$ & $\begin{array}{c}0 \\
\text { residue } 5 \\
\end{array}$ & $\begin{array}{c}0 \\
\text { residue } 6\end{array}$ & $\begin{array}{c}\mathbf{R} \\
\text { original }\end{array}$ & $\begin{array}{c}\mathbf{R} \\
\text { residue } 5 \\
\end{array}$ & $\begin{array}{c}\text { R } \\
\text { residue } 6 \\
\end{array}$ & $\begin{array}{c}S \\
\text { original }\end{array}$ & $\begin{array}{c}\text { S } \\
\text { residue } 5 \\
\end{array}$ & $\begin{array}{c}\text { S } \\
\text { residue } 6\end{array}$ & $\begin{array}{c}\mathbf{T} \\
\text { original }\end{array}$ \\
\hline Weight loss & 33.3 & - & 8.5 & 34.6 & - & 7.1 & 18.5 & - & 22.0 & 44.1 & - & 8.4 & 21.8 & - \\
\hline Albite & 11.7 & 8.3 & 9.7 & 15.0 & 14.7 & 14.1 & 11.5 & 23.0 & 31.3 & 24.4 & 16.9 & 9.6 & 6.3 & 12.9 \\
\hline Anorthite & 4.8 & 11.8 & 10.2 & 3.7 & 7.0 & 0.8 & 4.2 & 13.7 & 0.1 & 4.6 & 3.4 & 0.0 & 1.3 & 4.3 \\
\hline Augite & - & - & - & - & - & - & - & - & - & - & - & - & - & - \\
\hline Calcite & - & - & - & - & - & - & - & - & - & - & - & - & - & - \\
\hline Chalcopyrite & - & - & - & - & - & - & - & 0.8 & 0.5 & 0.1 & 0.2 & 0.5 & 0.1 & 0.2 \\
\hline Chlorite & 3.5 & 4.3 & 2.3 & 2.4 & 3.8 & 1.9 & 2.6 & 0.3 & 1.0 & 0.9 & 1.2 & 1.0 & 1.9 & 4.2 \\
\hline Copiapite & - & - & - & - & - & - & - & - & - & - & - & - & - & - \\
\hline Goethite & - & - & - & - & 5.2 & 3.0 & 0.0 & 10.7 & 10.4 & 1.3 & 10.8 & 2.8 & 2.0 & 9.4 \\
\hline Gypsum & - & - & - & - & - & - & - & 2.0 & 0.5 & 0.0 & 0.5 & 0.0 & 0.0 & 0.2 \\
\hline Hematite & - & - & - & - & - & - & - & 0.0 & - & - & 23.3 & 21.4 & 22.1 & 0.0 \\
\hline Hornblende & - & - & - & - & 0.0 & - & - & 0.0 & 4.1 & 0.6 & 0.0 & 0.0 & 0.0 & 8.7 \\
\hline Jarosite & - & - & - & - & 3.4 & 0.0 & 0.7 & 19.4 & 6.1 & 3.6 & 3.3 & 0.0 & 0.5 & 12.2 \\
\hline Kaolin & - & - & - & - & - & - & - & 0.0 & - & - & 0.0 & - & - & 0.0 \\
\hline Labradorite & - & - & - & - & - & - & - & - & - & - & - & - & - & - \\
\hline Lepidocrocite & - & - & - & - & - & - & - & - & - & - & - & - & - & - \\
\hline Melanterite & - & - & - & - & - & - & - & 0.0 & - & - & 0.3 & - & - & 1.3 \\
\hline Microcline & - & - & - & - & - & - & - & - & - & - & - & - & - & - \\
\hline Muscovite & 12.9 & 22.3 & 19.2 & 14.0 & 17.6 & 12.3 & 12.4 & 2.2 & 2.7 & 2.7 & 10.6 & 10.5 & 11.7 & 10.9 \\
\hline Orthoclase & - & - & - & - & - & - & - & - & - & - & - & - & - & - \\
\hline Pyrite & 0.1 & 5.5 & 6.1 & 0.3 & - & - & - & 0.0 & - & - & 0.3 & 1.2 & 0.0 & 0.0 \\
\hline Pyrrhotite & 2.6 & 14.6 & 10.4 & 1.7 & - & - & - & 0.0 & - & - & 0.0 & - & - & 0.0 \\
\hline Quartz & 30.8 & 32.9 & 33.3 & 28.1 & 46.3 & 59.4 & 50.1 & 19.5 & 15.9 & 12.5 & 23.1 & 43.9 & 30.6 & 29.0 \\
\hline Rozenite & - & - & - & - & - & - & - & 0.0 & - & - & 0.0 & - & - & 0.0 \\
\hline Rutile & - & - & - & - & - & - & - & - & - & - & - & - & - & - \\
\hline Sepiolite & - & - & - & - & 1.4 & 0.1 & 0.0 & - & - & - & - & - & - & 6.7 \\
\hline Sphalerite & 0.2 & 0.3 & 0.2 & 0.1 & - & - & - & 3.1 & 1.4 & 0.6 & 0.3 & 0.3 & 0.6 & 0.0 \\
\hline Talc & 0.0 & 0.0 & - & 0.0 & 0.7 & 1.5 & 0.0 & 5.1 & 4.1 & 4.4 & 5.6 & 0.2 & 1.1 & 0.0 \\
\hline Vermiculite & - & - & - & - & - & - & - & - & - & - & - & - & - & - \\
\hline Chi-square $^{2}$ & 4.4 & 5.0 & 3.7 & 3.8 & 4.3 & 3.8 & 3.8 & 5.6 & 4.1 & 4.0 & 4.3 & 3.2 & 3.4 & 4.9 \\
\hline
\end{tabular}


Appendix 1. Estimates of mineral abundances in original unleached samples and in residues after extraction steps 5 and 6 normalized with respect to measured weight loss. Values given in weight percent.-Continued

\begin{tabular}{|c|c|c|c|c|c|c|c|c|c|c|c|c|c|c|}
\hline $\begin{array}{l}\text { Extract ID } \\
\text { Sample split }\end{array}$ & $\begin{array}{c}\mathbf{T} \\
\text { residue } \\
\mathbf{5} \\
\end{array}$ & $\begin{array}{c}\mathbf{T} \\
\text { residue } \\
\mathbf{6} \\
\end{array}$ & $\begin{array}{c}\text { U } \\
\text { original }\end{array}$ & $\begin{array}{c}\text { U } \\
\text { residue } 5\end{array}$ & $\begin{array}{c}\text { U } \\
\text { residue } 6\end{array}$ & $\begin{array}{c}\mathrm{v} \\
\text { original }\end{array}$ & $\begin{array}{c}\mathrm{v} \\
\text { residue } 5\end{array}$ & $\begin{array}{c}\mathbf{v} \\
\text { residue } \\
6\end{array}$ & $\begin{array}{c}\text { W } \\
\text { original }\end{array}$ & $\begin{array}{c}\text { W } \\
\text { residue } 5\end{array}$ & $\begin{array}{c}\text { W } \\
\text { residue } 6\end{array}$ & $\begin{array}{c}\text { NZ- } \\
\text { Newmont- } \\
\text { A } \\
X \\
\text { original } \\
\end{array}$ & $\begin{array}{c}\text { NZ- } \\
\text { Newmont- } \\
\text { A } \\
\text { X } \\
\text { residue } 5 \\
\end{array}$ & $\begin{array}{c}\text { NZ-Newmont- } \\
\text { A } \\
\text { X } \\
\text { residue } 6 \\
\end{array}$ \\
\hline Weight loss & 19.8 & 39.9 & - & 15.6 & 33.7 & - & 18.9 & 39.4 & - & 22.6 & 48.9 & - & 4.6 & 13.1 \\
\hline Albite & 17.2 & 14.4 & 6.2 & 10.6 & 8.7 & 2.2 & 3.0 & 1.9 & 4.5 & 4.3 & 3.9 & - & - & - \\
\hline Anorthite & 6.7 & 5.6 & 5.5 & 8.0 & 3.0 & 0.9 & 0.7 & 0.1 & 0.0 & 0.1 & 0.0 & 7.2 & 7.7 & 7.5 \\
\hline Augite & - & - & - & - & - & - & - & - & - & - & - & 2.3 & 4.8 & 4.5 \\
\hline Calcite & - & - & - & - & - & 0.8 & 1.0 & 0.4 & 0.2 & 0.2 & 0.4 & - & - & - \\
\hline Chalcopyrite & 0.3 & 0.1 & 0.2 & 0.6 & 0.0 & 1.8 & 0.7 & 0.2 & 1.8 & 0.7 & 0.0 & - & - & - \\
\hline Chlorite & 3.0 & 1.2 & 4.1 & 3.4 & 1.9 & 0.6 & 4.3 & 2.2 & 0.0 & - & - & 3.8 & 2.6 & 3.1 \\
\hline Copiapite & - & - & - & - & - & 0.2 & - & - & 0.6 & - & - & - & - & - \\
\hline Goethite & 4.7 & 0.1 & 5.5 & 4.3 & 2.1 & 27.3 & 16.3 & 11.3 & 8.7 & 6.0 & 1.7 & - & - & - \\
\hline Gypsum & 0.0 & 0.0 & 0.4 & 0.0 & 0.0 & 2.4 & 1.5 & 0.0 & 3.0 & 2.2 & 0.0 & - & - & - \\
\hline Hematite & - & - & 10.6 & 14.3 & 12.8 & 6.8 & 7.5 & 5.1 & - & - & - & - & - & - \\
\hline Hornblende & 2.5 & 0.0 & 12.3 & 0.3 & 4.5 & 4.6 & 1.6 & 0.0 & 0.4 & 0.1 & 0.0 & - & - & - \\
\hline Jarosite & 2.9 & 0.6 & 9.2 & 1.7 & 1.2 & 7.5 & 2.8 & 0.7 & 13.6 & 3.4 & 1.2 & - & - & - \\
\hline Kaolin & - & - & 0.0 & - & - & 2.3 & 2.9 & 1.3 & 2.1 & 1.5 & 0.3 & - & - & - \\
\hline Labradorite & - & - & - & - & - & 0.0 & 2.3 & 2.0 & 7.8 & 11.0 & 7.6 & - & - & - \\
\hline Lepidocrocite & - & - & - & - & - & 0.0 & - & - & 0.0 & - & - & - & - & - \\
\hline Melanterite & - & - & 1.1 & - & - & 0.0 & - & - & 0.2 & - & - & - & - & - \\
\hline Microcline & - & - & - & - & - & - & - & - & - & - & - & 4.4 & 1.7 & 7.4 \\
\hline Muscovite & 14.7 & 12.3 & 9.1 & 13.7 & 8.2 & 3.6 & 8.4 & 6.1 & 8.8 & 6.7 & 6.2 & - & - & - \\
\hline Orthoclase & - & - & - & - & - & - & - & - & - & - & - & 13.2 & 13.4 & 7.2 \\
\hline Pyrite & - & - & 0.0 & - & - & 0.0 & - & - & 0.1 & - & - & 2.7 & 2.1 & 0.0 \\
\hline Pyrrhotite & - & - & 0.0 & - & - & 0.0 & - & - & 0.0 & - & - & - & - & - \\
\hline Quartz & 28.2 & 25.7 & 33.3 & 27.4 & 23.9 & 33.0 & 27.8 & 29.2 & 38.2 & 41.1 & 29.7 & 66.4 & 63.0 & 57.2 \\
\hline Rozenite & - & - & 0.0 & - & - & 0.0 & - & - & 0.0 & - & - & - & - & - \\
\hline Rutile & - & - & - & - & - & 0.0 & - & - & 0.1 & - & - & - & - & - \\
\hline Sepiolite & 0.1 & 0.2 & 2.4 & 0.1 & 0.1 & 5.0 & 0.1 & 0.1 & 9.4 & 0.1 & 0.1 & - & - & - \\
\hline Sphalerite & - & - & 0.0 & - & - & 0.8 & 0.1 & 0.0 & 0.2 & 0.0 & 0.0 & - & - & - \\
\hline Talc & - & - & 0.0 & - & - & - & - & - & - & - & - & - & - & - \\
\hline Vermiculite & - & - & - & - & - & - & - & - & - & - & - & - & - & - \\
\hline Chi-square $^{2}$ & 3.5 & 4.2 & 3.9 & 3.4 & 3.6 & 4.8 & 3.2 & 2.9 & 4.1 & 3.0 & 4.4 & 3.7 & 3.2 & 3.8 \\
\hline
\end{tabular}

${ }^{1}$ Phase identified by JADE software but likely a vermiculite-type mixed layer clay.

${ }^{2}$ Chi-square is a computed statistical residual to measure the fit of refinement. Chi-square $=1$ for perfect correspondence between least-squares model and

observed data. Values below 6 are considered reasonable fits for these complex mine wastes due to systematic errors and imperfect physical corrections. 
Appendix 2. Concentration of elements in $\mathrm{mg} / \mathrm{kg}$ for samples used in sequential extractions.

\begin{tabular}{|c|c|c|c|c|c|c|c|c|c|c|c|c|c|c|c|c|c|c|c|c|}
\hline Sample ID & Extract ID & $\mathbf{A g}^{1}$ & Al & As & $\mathrm{Ba}$ & $\mathrm{Be}$ & $\mathbf{B i}$ & $\mathrm{Ca}$ & Cd & Ce & Co & $\mathrm{Cr}$ & Cs & $\mathrm{Cu}$ & $\mathrm{Fe}$ & $\mathbf{G a}$ & $\mathbf{K}$ & La & Li & Mg \\
\hline $\begin{array}{l}\text { EMV-SED- } \\
\text { LOC05 }\end{array}$ & $\mathrm{B}, \mathrm{C}, \mathrm{N}$ & $<2$ & 41,700 & 4.9 & 153 & 0.87 & 0.8 & 10,400 & 0.53 & 12.6 & 21.3 & 52.5 & 1.6 & 568 & 160,000 & 9.6 & 12,200 & 6.5 & 9.6 & 7,180 \\
\hline $\begin{array}{l}\text { EMV-SED- } \\
\text { LOC05-D }\end{array}$ & $\begin{array}{c}\mathrm{B}, \mathrm{C}, \mathrm{N} \\
\text { (duplicate) }\end{array}$ & $<2$ & 38,800 & 4.9 & 139 & 1.4 & 0.82 & 9,750 & 0.42 & 11.6 & 19.3 & 53.4 & 1.6 & 519 & 165,000 & 9.3 & 12,300 & 5.9 & 8.7 & 7,100 \\
\hline $\begin{array}{l}\text { EMV-SED- } \\
\text { LOC06 }\end{array}$ & $\mathrm{D}$ & $<2$ & 36,700 & $<1$ & 178 & 1.5 & 0.14 & 9,330 & 0.08 & 19.3 & 7.6 & 49.5 & 2.3 & 277 & 45,000 & 8.4 & 6,760 & 9.6 & 20.4 & 7,830 \\
\hline EMV-SED-04 & $\mathrm{E}$ & $<2$ & 38,500 & $<1$ & 170 & 1.6 & 0.15 & 10,400 & 0.32 & 20.7 & 12.6 & 48.3 & 2.4 & 297 & 44,900 & 8.6 & 6,170 & 10.4 & 21.9 & 8,660 \\
\hline EMV-SED-06 & $\mathrm{F}$ & $<2$ & 37,200 & $<1$ & 158 & 1.6 & 0.11 & 11,400 & 0.05 & 20.3 & 8.3 & 45 & 2 & 188 & 41,200 & 8 & 6,110 & 10 & 19.4 & 7,680 \\
\hline $\begin{array}{l}\text { EMV-SED- } \\
701\end{array}$ & G & $<2$ & 33,000 & $<1$ & 144 & 1.5 & 0.08 & 9,430 & 0.08 & 16.4 & 7.7 & 41 & 1.9 & 97 & 30,500 & 7.2 & 5,010 & 8 & 19.6 & 7,560 \\
\hline $\begin{array}{l}\text { EMV-SED- } \\
702\end{array}$ & $\mathrm{H}$ & $<2$ & 39,900 & $<1$ & 188 & 1.5 & 0.13 & 11,100 & 0.27 & 20.6 & 9 & 47.2 & 2.4 & 214 & 46,000 & 9 & 7,530 & 10.2 & 20.8 & 8,550 \\
\hline Ely-SD-09 & I & 3.6 & 42,600 & $<1$ & 208 & 1.2 & 2.24 & 10,300 & 0.38 & 15.9 & 15.2 & 68.1 & 1.8 & 2,840 & 162,000 & 12.4 & 10,400 & 8.1 & 5.7 & 6,870 \\
\hline 1139830-SD & $\mathrm{J}$ & 5.8 & 27,700 & 17.8 & 152 & 1 & 2.92 & 9,100 & 5.5 & 10.4 & 50.3 & 30.3 & 1 & 6,940 & 208,000 & 9.1 & 7,880 & 4.9 & 4.1 & 6,120 \\
\hline 04Smith3 & $\mathrm{K}$ & 6.4 & 28,400 & $<1$ & 175 & 1.1 & 2.71 & 5,250 & 0.16 & 9.8 & 30.1 & 28.2 & 0.84 & 1,480 & 234,000 & 12.2 & 11,800 & 6.5 & 2.3 & 4,600 \\
\hline CLHN-TP-2 & $\mathrm{L}$ & 5.5 & 51,700 & 48.5 & 163 & 0.89 & 19 & 53,900 & 36.6 & 19.3 & 4.7 & 31.4 & 2.7 & 2,350 & 36,100 & 28.5 & 7,460 & 8 & 44.8 & 124,000 \\
\hline TP1-S-unox & $\mathrm{O}, \mathrm{P}$ & $<2$ & 62,400 & 8.5 & 158 & 0.78 & 1.16 & 10,600 & 21.4 & 23.8 & 344 & 132 & 4.9 & 635 & 158,000 & 14.4 & 16,700 & 12.1 & 22 & 14,100 \\
\hline TP1-S ox & $\mathrm{Q}$ & $<2$ & 50,100 & 3.3 & 158 & 0.94 & 0.7 & 9,070 & 0.18 & 6.6 & 27.3 & 69.8 & 1.4 & 86 & 79,300 & 13.3 & 13,700 & 3.5 & 7 & 6,350 \\
\hline 02ТР3А & $\mathrm{R}$ & 5 & 34,200 & 6.7 & 27.2 & 0.2 & 2.51 & 5,700 & 0.32 & 1.2 & 4.8 & 71.4 & 2.1 & 2,000 & 157,000 & 9.5 & 9,570 & 0.55 & $\begin{array}{c}< \\
0.3\end{array}$ & 5,830 \\
\hline 02ТР3C & S & 11.5 & 37,000 & 20.1 & 37.2 & 0.26 & 6.86 & 3,580 & 1.1 & 1.5 & 40.2 & 70.9 & 1 & 1,160 & 246,000 & 11.2 & 10,100 & 0.79 & 3.3 & 2,740 \\
\hline 02Ely $2 \mathrm{~A}$ & $\mathrm{~T}$ & 4.4 & 47,000 & $<1$ & 237 & 1.2 & 2.61 & 11,200 & 0.48 & 16.2 & 18.9 & 68.3 & 2.3 & 2,500 & 174,000 & 14.1 & 14,200 & 8.9 & 3 & 5,820 \\
\hline 02Ely 10A & $\mathrm{U}$ & 15.4 & 39,200 & 1.6 & 192 & 0.86 & 9.46 & 9,080 & 1.1 & 15.1 & 35.6 & 77.9 & 2.2 & 1,970 & 205,000 & 11 & 11,700 & 7.9 & 4.1 & 5,580 \\
\hline 04PKHL9 & V & 25.4 & 16,600 & 6.5 & 177 & 0.53 & 7.76 & 4,410 & 2.2 & 8.6 & 91.7 & 20.7 & 1 & 10,300 & 237,000 & 6.3 & 9,400 & 4.3 & $\begin{array}{c}< \\
0.3\end{array}$ & 2,610 \\
\hline 04PKHL11 & $\mathrm{W}$ & 9.1 & 28,300 & 2.6 & 197 & 1 & 6.26 & 9,640 & 0.72 & 9 & 42.6 & 28.2 & 1.1 & 8,140 & 215,000 & 11.9 & 14,500 & 5 & 2.4 & 4,440 \\
\hline $\begin{array}{l}\text { NZ-Newmont- } \\
\text { A }\end{array}$ & $\mathrm{X}$ & 17.8 & 51,400 & 41.5 & 465 & 1.3 & 0.06 & 4,260 & 0.28 & 16.4 & 10.8 & 108 & 9.2 & 102 & 26,800 & 9.6 & 31,200 & 8.4 & 95.5 & 7,780 \\
\hline
\end{tabular}


Appendix 2. Concentration of elements in $\mathrm{mg} / \mathrm{kg}$ for samples used in sequential extractions.-Continued

\begin{tabular}{|c|c|c|c|c|c|c|c|c|c|c|c|c|c|c|c|c|c|c|c|c|c|}
\hline Sample ID & Mn & Mo & $\mathrm{Na}$ & Nb & $\mathrm{Ni}$ & $\mathbf{P}$ & $\mathbf{P b}$ & $\mathbf{R b}$ & Sb & Sc & Se & $\mathrm{Sr}$ & Th & $\mathrm{Ti}$ & $\mathrm{TI}$ & $\mathbf{U}$ & V & $\mathbf{Y}$ & Zn & Job No. & Lab No. \\
\hline & 521 & 9.3 & 13,300 & 2.4 & 12.3 & 286 & 29.2 & 36.6 & 0.1 & 8.1 & 12 & 94.8 & 2.19 & 1,640 & 0.41 & 0.58 & 76.7 & 8 & 265 & MRP-06905 & C-275581 \\
\hline $\begin{array}{l}\text { EMV-SED- } \\
\text { LOC05-D }\end{array}$ & 433 & 9.2 & 12,300 & 2.4 & 12.3 & 292 & 27.8 & 37.5 & 0.1 & 7.6 & 14 & 91.6 & 2.21 & 1,630 & 0.43 & 0.58 & 75.8 & 7.3 & & MRP-06905 & C-275582 \\
\hline $\begin{array}{l}\text { EMV-SED- } \\
\text { LOC06 }\end{array}$ & 542 & 0.9 & 8,000 & 3.2 & 16.4 & 303 & 10.2 & 40.2 & $\Omega 00$ & 6.7 & 0.82 & 159 & 3.38 & 1,820 & 0.22 & 0.62 & 50.3 & 10.4 & 63 & MRP-06905 & C-275583 \\
\hline EMV-SED-04 & 424 & 1.1 & 8,900 & 4.2 & 18.7 & 425 & 12 & 38 & $<0.04$ & 6.3 & 1.6 & 175 & 3.52 & 2,120 & 0.22 & 0.73 & 53.1 & 10 & 105 & MRP-06905 & C-275584 \\
\hline EMV-SED-06 & 1,020 & & & 5 & 16.7 & 351 & 9.28 & 35.4 & & & & 156 & 3.32 & 2,520 & & 0.68 & 50.8 & 15.6 & 57 & MRP-06905 & C-275585 \\
\hline $\begin{array}{l}\text { EMV-SED- } \\
701\end{array}$ & 506 & 0.41 & 7,520 & 4.1 & 15.6 & 323 & 8.91 & 30.9 & $<0.04$ & 5.9 & 0.43 & 161 & 2.83 & 2,000 & 0.17 & 0.55 & 43.9 & 9.6 & 61 & MRP-06905 & C-275586 \\
\hline $\begin{array}{l}\text { EMV-SED- } \\
702\end{array}$ & 737 & 0.5 & 8,210 & 5.4 & 18.6 & 352 & 9.93 & 43.1 & $<0.04$ & 8.6 & 0.77 & 163 & 3.66 & 2,660 & 0.22 & 0.7 & 59.5 & 13 & 91 & MRP-06905 & C-275587 \\
\hline Ely-SD-09 & 1,050 & 20.3 & 12,100 & 5.6 & 10.5 & 413 & 51.4 & 43 & 0.32 & 9.8 & 43 & 87.5 & 3.08 & 2,720 & 0.47 & 0.8 & 116 & 8.9 & 153 & MRP-06905 & C- 275590 \\
\hline 1139830-SD & 7 & 16.5 & 5,650 & 7 & 8.4 & 379 & 55.8 & 31.6 & 1.2 & 3.8 & 44 & 92 & 3.03 & 1,910 & 0.49 & 0.82 & 54.6 & 10.7 & 1,110 & MR & C-275600 \\
\hline 04Smith3 & & & 7,850 & 2.8 & 6 & 818 & 79 & 49.2 & & 3.8 & 2.5 & 63.1 & 2.48 & 1,130 & 1.11 & 0.72 & 125 & 6.7 & & MR & 75597 \\
\hline CLHN-TP-2 & 1,96 & & & 4 & & 1 & & 32.1 & & & & 47.8 & 2.93 & & 2.28 & & 3. & 37.4 & & & 75592 \\
\hline & & & & 2. & 90.6 & & & 69.8 & & & & & & & & & & & & & \\
\hline TP1-S ox & 302 & 12.4 & 13,900 & 1.9 & 9.1 & 147 & 32.7 & 48.3 & 0.08 & 8.6 & 10 & 75.4 & 0.91 & 1,440 & 0.61 & 0.59 & 80.8 & 5.5 & 298 & MRP-06905 & C- 275589 \\
\hline 02TP3A & 288 & 29.2 & 20,700 & $\begin{array}{c}< \\
0.1\end{array}$ & 0.8 & 82.2 & 47.1 & 43.6 & 0.06 & 6 & 31 & 27.6 & $\begin{array}{c}< \\
0.1\end{array}$ & 1,210 & 1.03 & 0.19 & 71 & 1.6 & 248 & MRP-06905 & C-275593 \\
\hline 02ТР $3 \mathrm{C}$ & 268 & 82.8 & 12,600 & $\begin{array}{l}< \\
0.1\end{array}$ & 9.4 & 76.5 & 78.2 & 29.3 & 0.1 & 7.8 & 110 & 25.4 & 0.13 & 1,100 & 1.02 & 0.38 & 87.3 & 1.7 & 425 & MRP-06905 & C-275594 \\
\hline 02Ely2A & 1,73 & 15.8 & 14,200 & 3.6 & 7.7 & 45 & 50. & 58 & & & & & 2.5 & 4,15 & 0.49 & & & & & & C-275595 \\
\hline 02Ely10A & 1,170 & & & 2.8 & 14.3 & 402 & & 47.6 & & & 75 & & & & & & & 8. & & & \\
\hline 04PKHL9 & 212 & 33.2 & & 4.9 & 9.5 & 163 & 153 & 42.2 & 3.9 & 2.4 & 140 & 63.4 & & & 0.71 & & 47 & & & & C-275598 \\
\hline 04PKHL11 & 205 & 25.8 & 6,350 & 6.7 & 4 & 343 & 91.5 & 64.4 & 0.1 & 4.3 & 62 & 84.5 & 2.25 & 1,820 & 1.21 & 0.63 & 77.4 & 4.9 & 276 & MRP-06905 & C-275599 \\
\hline $\begin{array}{l}\text { NZ-Newmont- } \\
\text { A }\end{array}$ & 2,930 & 1.3 & 4,510 & 3.9 & 30.3 & 211 & 89.1 & 166 & 14.3 & 8.7 & 1.7 & 84 & 3.56 & 1,670 & 2.33 & 0.71 & 66.2 & 9.7 & 220 & MRP-06905 & C-275591 \\
\hline
\end{tabular}

${ }^{1}$ Results from ICP-MS analysis for all elements except Se, which was determined by HG-AAS. 
Appendix 3. Amounts of elements leached in sequential extraction experiments given in mg/kg'.

\begin{tabular}{|c|c|c|c|c|c|c|c|c|c|c|c|c|c|c|c|}
\hline Extract ID & Sample ID & $\begin{array}{l}\text { Extract } \\
\text { Step }\end{array}$ & Lab No & Job No. & $\mathbf{A g}^{2}$ & Al & As & $\mathrm{Ba}$ & $\mathrm{Be}$ & $\mathrm{Bi}$ & $\mathrm{Ca}$ & Cd & $\mathrm{Ce}$ & Co & $\mathrm{Cr}$ \\
\hline B-1 & EMV-SED-LOC05 & Extract 1 & $02-1$ & - & $<0.6$ & 10.6 & $<0.2$ & $<0.04$ & $<0.01$ & $<0.04$ & 181 & 0.01 & - & 1.62 & $<0.2$ \\
\hline B-2 & EMV-SED-LOC05 & Extract 2 & $02-2$ & - & $<0.6$ & 58.0 & $<0.2$ & 0.2 & $<0.01$ & $<0.04$ & $<136^{3}$ & 0.02 & - & 0.27 & $<0.2^{4}$ \\
\hline B-3 & EMV-SED-LOC05 & Extract 3 & $02-3$ & - & $<0.6$ & 94.5 & 0.4 & $<0.04$ & $<0.01$ & $<0.04$ & $<40$ & $<0.004$ & - & 0.17 & $<0.2$ \\
\hline B-4 & EMV-SED-LOC05 & Extract 4 & $02-4$ & - & $<0.6$ & 141 & $<0.2$ & 1.19 & $<0.01$ & $<0.04$ & 43.8 & 0.01 & - & 0.24 & 0.5 \\
\hline B-5 & EMV-SED-LOC05 & Extract 5 & $02-5$ & - & $<0.6$ & 670 & 0.6 & 19.2 & 0.04 & 0.53 & $<40$ & $<0.004$ & - & 1.27 & 6.7 \\
\hline B-5R & EMV-SED-LOC05 & Residue 5 & C-275601 & MRP-06906 & $<2$ & 36,700 & 2.9 & 98.2 & 0.83 & 0.23 & 7,710 & 0.28 & 10 & 9.5 & 55.6 \\
\hline B-6R & EMV-SED-LOC05 & Residue 6 & C-275623 & MRP-06906 & $<2$ & 61,500 & $<1$ & 152 & 1.4 & $<0.06$ & 16,000 & 0.05 & 11.1 & 5.2 & 83.3 \\
\hline $\mathrm{C}-1$ & EMV-SED-LOC05 & Extract 1 & $03-1$ & - & $<0.6$ & 10.3 & $<0.2$ & $<0.04$ & 0.01 & $<0.04$ & 225 & 0.01 & - & 1.63 & $<0.2$ \\
\hline $\mathrm{C}-2$ & EMV-SED-LOC05 & Extract 2 & $03-2$ & - & $<0.6$ & 57.2 & $<0.2$ & 0.20 & $<0.01$ & $<0.04$ & $<136$ & 0.02 & - & 0.31 & 0.4 \\
\hline $\mathrm{C}-3$ & EMV-SED-LOC05 & Extract 3 & $03-3$ & - & $<0.6$ & 102 & 0.4 & $<0.04$ & 0.02 & $<0.04$ & 38.6 & $<0.004$ & - & 0.19 & $<0.2$ \\
\hline $\mathrm{C}-4$ & EMV-SED-LOC05 & Extract 4 & $03-4$ & - & $<0.6$ & 139 & $<0.2$ & 1.09 & $<0.01$ & $<0.04$ & 38.8 & 0.02 & - & 0.26 & 0.4 \\
\hline C-5 & EMV-SED-LOC05 & Extract 5 & $03-5$ & - & $<0.6$ & 688 & 0.5 & 20.6 & 0.03 & 0.50 & $<40$ & $<0.004$ & - & 1.29 & 11.7 \\
\hline$C-5 R$ & EMV-SED-LOC05 & Residue 5 & C-275602 & MRP-06906 & $<2$ & 39,300 & 3.6 & 105 & 0.83 & 0.35 & 8,080 & 0.26 & 8.4 & 11.2 & 56.2 \\
\hline$C-6 \mathrm{R}$ & EMV-SED-LOC05 & Residue 6 & C-275624 & MRP-06906 & $<2$ & 61,500 & $<1$ & 172 & 1.4 & 0.06 & 15,900 & 0.06 & 13.6 & 5.3 & 143 \\
\hline D-1 & EMV-SED-LOC06 & Extract 1 & $04-1$ & - & $<0.6$ & 7.80 & $<0.2$ & 0.05 & $<0.01$ & $<0.04$ & $<40$ & $<0.004$ & - & 0.33 & $<0.2$ \\
\hline D-2 & EMV-SED-LOC06 & Extract 2 & $04-2$ & - & $<0.6$ & 61.6 & $<0.2$ & 0.36 & $<0.01$ & $<0.04$ & $<136$ & 0.008 & - & 0.07 & 0.4 \\
\hline D-3 & EMV-SED-LOC06 & Extract 3 & $04-3$ & - & $<0.6$ & 110 & 0.3 & $<0.04$ & 0.01 & $<0.04$ & $<40$ & $<0.004$ & - & 0.08 & $<0.2$ \\
\hline D-4 & EMV-SED-LOC06 & Extract 4 & $04-4$ & - & $<0.6$ & 311 & $<0.2$ & 2.63 & $<0.01$ & $<0.04$ & 237 & 0.01 & - & 0.21 & 0.7 \\
\hline D-5 & EMV-SED-LOC06 & Extract 5 & $04-5$ & - & $<0.6$ & 1,382 & $<0.2$ & 5.38 & 0.04 & 0.04 & 256 & $<0.004$ & - & 0.96 & 9.4 \\
\hline $\mathrm{D}-5 \mathrm{R}$ & EMV-SED-LOC06 & Residue 5 & C-275603 & MRP-06906 & $<2$ & 35,900 & $<1$ & 159 & 1.7 & $<0.06$ & 8,580 & 0.01 & 10.9 & 6.1 & 45 \\
\hline D-6R & EMV-SED-LOC06 & Residue 6 & C- 275625 & MRP-06906 & $<2$ & 37,300 & $<1$ & 157 & 1.6 & $<0.06$ & 10,800 & 0.02 & 9 & 3.8 & 61.3 \\
\hline E-1 & EMV-SED-04 & Extract 1 & $05-1$ & - & $<0.6$ & 10.4 & $<0.2$ & 0.1 & 0.02 & $<0.04$ & 98.0 & 0.02 & - & 0.74 & $<0.2$ \\
\hline E-2 & EMV-SED-04 & Extract 2 & $05-2$ & - & $<0.6$ & 109 & $<0.2$ & 0.83 & $<0.01$ & $<0.04$ & $<136$ & 0.03 & - & 0.29 & 1.4 \\
\hline E-3 & EMV-SED-04 & Extract 3 & $05-3$ & - & $<0.6$ & 185 & 0.4 & 0.08 & 0.02 & $<0.04$ & $<40$ & 0.006 & - & 0.29 & 0.3 \\
\hline E-4 & EMV-SED-04 & Extract 4 & $05-4$ & - & $<0.6$ & 455 & $<0.2$ & 3.94 & 0.02 & $<0.04$ & 325 & 0.02 & - & 0.45 & 0.9 \\
\hline E-5 & EMV-SED-04 & Extract 5 & $05-5$ & - & $<0.6$ & 2,032 & $<0.2$ & 7.76 & 0.06 & 0.08 & 283 & $<0.004$ & - & 2.05 & 12.3 \\
\hline E-5R & EMV-SED-04 & Residue 5 & C-275604 & MRP-06906 & $<2$ & 32,400 & $<1$ & 121 & 1.4 & $<0.06$ & 7,880 & 0.03 & 10.1 & 6.5 & 40.6 \\
\hline E-6R & EMV-SED-04 & Residue 6 & C-275626 & MRP-06906 & $<2$ & 36,500 & $<1$ & 139 & 1.8 & $<0.06$ & 11,000 & $<0.007$ & 11.2 & 2.6 & 40.4 \\
\hline F-1 & EMV-SED-06 & Extract 1 & $06-1$ & - & $<0.6$ & 5.14 & $<0.2$ & 0.2 & $<0.01$ & $<0.04$ & 116 & $<0.004$ & - & 0.19 & $<0.2$ \\
\hline F-2 & EMV-SED-06 & Extract 2 & $06-2$ & - & $<0.6$ & 63.2 & $<0.2$ & 0.71 & $<0.01$ & $<0.04$ & $<136$ & 0.01 & - & 0.07 & 0.9 \\
\hline F-3 & EMV-SED-06 & Extract 3 & $06-3$ & - & $<0.6$ & 126 & 0.4 & 0.08 & 0.01 & $<0.04$ & $<40$ & $<0.004$ & - & 0.10 & 0.2 \\
\hline F-4 & EMV-SED-06 & Extract 4 & $06-4$ & - & $<0.6$ & 376 & $<0.2$ & 3.03 & 0.02 & $<0.04$ & 285 & 0.01 & - & 0.41 & 0.8 \\
\hline F-5 & EMV-SED-06 & Extract 5 & $06-5$ & - & $<0.6$ & 1,852 & $<0.2$ & 5.11 & 0.06 & 0.07 & 404 & $<0.004$ & - & 1.64 & 17.6 \\
\hline F-5R & EMV-SED-06 & Residue 5 & C-275605 & MRP-06906 & $<2$ & 34,500 & $<1$ & 163 & 1.2 & $<0.06$ & 9,120 & 0.03 & 16.3 & 4.1 & 46.3 \\
\hline F-6R & EMV-SED-06 & Residue 6 & C- 275627 & MRP-06906 & $<2$ & 41,500 & $<1$ & 197 & 1.7 & $<0.06$ & 12,200 & 0.01 & 21.8 & 3.6 & 64.5 \\
\hline G-1 & EMV-SED-701 & Extract 1 & $07-1$ & - & $<0.6$ & 11.3 & $<0.2$ & 0.04 & 0.01 & $<0.04$ & 95.9 & 0.004 & - & 0.39 & $<0.2$ \\
\hline G-2 & EMV-SED-701 & Extract 2 & $07-2$ & - & $<0.6$ & 79.6 & $<0.2$ & 0.72 & $<0.01$ & $<0.04$ & $<136$ & 0.009 & - & 0.11 & 0.8 \\
\hline G-3 & EMV-SED-701 & Extract 3 & $07-3$ & - & $<0.6$ & 139 & 0.3 & 0.09 & 0.01 & $<0.04$ & $<40$ & $<0.004$ & - & 0.12 & 0.3 \\
\hline G-4 & EMV-SED-701 & Extract 4 & $07-4$ & - & $<0.6$ & 432 & $<0.2$ & 5.13 & 0.01 & $<0.04$ & 387 & 0.01 & - & 0.24 & 0.9 \\
\hline G-5 & EMV-SED-701 & Extract 5 & $07-5$ & - & $<0.6$ & 1,842 & $<0.2$ & 7.50 & 0.04 & 0.05 & 365 & $<0.004$ & - & 1.74 & 17.3 \\
\hline G-5R & EMV-SED-701 & Residue 5 & C-275606 & MRP-06906 & $<2$ & 33,800 & $<1$ & 128 & 1.7 & $<0.06$ & 9,800 & 0.14 & 8.9 & 5.8 & 41.1 \\
\hline G-6R & EMV-SED-701 & Residue 6 & C- 275628 & MRP-06906 & $<2$ & 30,400 & $<1$ & 111 & 1.6 & $<0.06$ & 10,100 & $<0.007$ & 7.3 & 2.5 & 33.2 \\
\hline
\end{tabular}


Appendix 3. Amounts of elements leached in sequential extraction experiments given in $\mathrm{mg} / \mathrm{kg}^{1}$.-Continued

\begin{tabular}{|c|c|c|c|c|c|c|c|c|c|c|c|c|c|c|c|c|c|}
\hline Extract ID & Cs & $\mathrm{Cu}$ & $\mathrm{Fe}$ & $\mathbf{G a}$ & Ge & $\mathbf{K}$ & La & $\mathbf{L i}$ & Mg & Mn & Mo & $\mathrm{Na}$ & $\mathbf{N b}$ & $\mathrm{Ni}$ & $\mathbf{P}$ & $\mathbf{P b}$ & $\mathbf{R b}$ \\
\hline B-1 & 0.03 & 1.7 & 54 & $<0.01$ & 0.02 & - & - & $<0.2$ & 95.3 & 6.7 & $<0.4$ & $<20$ & - & 0.7 & - & $<0.01$ & 0.02 \\
\hline B-2 & 0.01 & 9.4 & 97 & 0.02 & 0.01 & - & - & 0.3 & 8.43 & $<0.7$ & $<0.4$ & $<20$ & - & 0.1 & - & $<0.5$ & 0.13 \\
\hline B-3 & 0.04 & 4.7 & 993 & $<0.01$ & 0.02 & - & - & 0.8 & 15.5 & 0.6 & $<0.4$ & $<20$ & - & $<0.08$ & - & $<0.2$ & 0.19 \\
\hline B-4 & 0.02 & 6.5 & 2,130 & 0.31 & $<0.01$ & - & - & $<0.2$ & 49.0 & 1.6 & $<0.4$ & - & - & 0.3 & - & 0.1 & 0.14 \\
\hline B-5 & 0.49 & 84.6 & 42,570 & 0.58 & 0.27 & - & - & 1.6 & 332 & 11.9 & 1.50 & 1,270 & - & 1.9 & - & 9.4 & 7.53 \\
\hline B-5R & 0.99 & 245 & 80,700 & 7.8 & - & 7,380 & 5.1 & 12.9 & 5,460 & 334 & 9 & 12,200 & 1.9 & 9.5 & 2,350 & 23.3 & 24.9 \\
\hline B-6R & 0.87 & 14.8 & 23,900 & 11.5 & - & 9,700 & 5.3 & 16.3 & 8,870 & 607 & 3.5 & 19,600 & 5.4 & 8.7 & 38.2 & 20.5 & 28.2 \\
\hline $\mathrm{C}-1$ & 0.03 & 2.3 & 22 & $<0.01$ & 0.01 & - & - & $<0.2$ & 81.6 & 5.9 & $<0.4$ & $<20$ & - & 0.7 & - & $<0.01$ & 0.03 \\
\hline $\mathrm{C}-2$ & 0.004 & 9.4 & 79 & 0.02 & $<0.01$ & - & - & $<0.2$ & 8.78 & $<0.7$ & $<0.4$ & $<20$ & - & 0.2 & - & $<0.5$ & 0.14 \\
\hline $\mathrm{C}-3$ & 0.03 & 5.1 & 951 & $<0.01$ & $<0.01$ & - & - & 0.6 & 18.8 & 0.6 & $<0.4$ & $<20$ & - & 0.1 & - & $<0.2$ & 0.18 \\
\hline C-4 & 0.01 & 6.3 & 2,490 & 0.36 & $<0.01$ & - & - & $<0.2$ & 44.9 & 1.7 & $<0.4$ & - & - & 0.3 & - & 0.08 & 0.12 \\
\hline C-5 & 0.41 & 86.6 & 42,270 & 0.58 & 0.26 & - & - & 2.0 & 355 & 13.6 & 1.50 & 1,830 & - & 6.0 & - & 9.3 & 7.60 \\
\hline C-5R & 1 & 289 & 92,000 & 8.7 & - & 8,010 & 4.1 & 11.8 & 5,410 & 584 & 7.1 & 12,800 & 4.1 & 9 & 3,160 & 19.9 & 27.5 \\
\hline C-6R & 0.88 & 32.1 & 26,200 & 11.4 & - & 10,100 & 6.6 & 16.7 & 9,200 & 808 & 14 & 19,000 & 4 & 22.5 & 53.3 & 21.2 & 28.7 \\
\hline D-1 & 0.03 & 2.9 & $<10$ & $<0.01$ & $<0.01$ & - & - & $<0.2$ & 23.6 & 2.2 & $<0.4$ & $<20$ & - & 0.2 & - & $<0.01$ & $<0.002$ \\
\hline D-2 & 0.009 & 7.8 & 46 & 0.02 & $<0.01$ & - & - & $<0.2$ & 4.84 & $<0.7$ & $<0.4$ & $<20$ & - & $<0.08$ & - & $<0.5$ & 0.11 \\
\hline D-3 & 0.04 & 4.2 & 641 & $<0.01$ & $<0.01$ & - & - & 0.9 & 16.6 & 1.0 & $<0.4$ & $<20$ & - & $<0.08$ & - & $<0.2$ & 0.15 \\
\hline D-4 & 0.04 & 19.8 & 1,250 & 0.2 & $<0.01$ & - & - & $<0.2$ & 93.5 & 8.7 & $<0.4$ & - & - & 0.4 & - & 0.95 & 0.09 \\
\hline D-5 & 0.36 & 41.0 & 10,370 & 0.57 & 0.09 & - & - & 3.8 & 676 & 27.6 & $<0.4$ & 269 & - & 3.0 & - & 1.2 & 2.39 \\
\hline D-5R & 2.1 & 74.3 & 29,200 & 7.6 & - & 6,410 & 5.5 & 20.6 & 6,820 & 464 & 0.78 & 8,590 & 4.6 & 12.1 & 824 & 8.24 & 35.6 \\
\hline D-6R & 0.67 & 28.9 & 16,500 & 6.4 & - & 5,310 & 4.5 & 14.5 & 4,160 & 481 & 1.8 & 10,500 & 6.7 & 11.1 & 19.7 & 8 & 17.2 \\
\hline E-1 & 0.03 & 4.4 & $<10$ & $<0.01$ & $<0.01$ & - & - & $<0.2$ & 34.6 & 9.7 & $<0.4$ & $<20$ & - & 0.3 & - & $<0.01$ & $<0.002$ \\
\hline E-2 & 0.02 & 18.0 & 64 & 0.02 & 0.01 & - & - & $<0.2$ & 9.95 & 2.7 & $<0.4$ & $<20$ & - & 0.2 & - & $<0.5$ & 0.13 \\
\hline E-3 & 0.04 & 9.2 & 889 & $<0.01$ & $<0.01$ & - & - & 0.7 & 22.3 & 3.5 & $<0.4$ & $<20$ & - & 0.2 & - & $<0.2$ & 0.21 \\
\hline E-4 & 0.05 & 17.4 & 1,220 & 0.2 & 0.01 & - & - & 0.3 & 139 & 12.0 & $<0.4$ & - & - & 0.6 & - & 0.76 & 0.17 \\
\hline E-5 & 0.39 & 92.6 & 11,570 & 0.79 & 0.09 & - & - & 5.4 & 1,100 & 32.2 & $<0.4$ & 379 & - & 4.9 & - & 2.0 & 2.99 \\
\hline E-5R & 1.6 & 100 & 21,800 & 6.6 & - & 5,250 & 5 & 18.6 & 6,320 & 282 & 0.41 & 8,520 & 2.5 & 13.7 & 802 & 7.67 & 30.5 \\
\hline E-6R & 0.51 & 4.3 & 8,980 & 6 & - & 4,700 & 5.4 & 13.2 & 4,050 & 325 & 0.49 & 11,000 & 5.8 & 7 & 19 & 9.58 & 14.9 \\
\hline F-1 & 0.02 & 2.2 & $<10$ & $<0.01$ & $<0.01$ & - & - & $<0.2$ & 24.1 & 2.2 & $<0.4$ & $<20$ & - & 0.1 & - & $<0.01$ & $<0.002$ \\
\hline $\mathrm{F}-2$ & 0.01 & 8.6 & 41 & 0.02 & $<0.01$ & - & - & $<0.2$ & 6.27 & $<0.7$ & $<0.4$ & $<20$ & - & $<0.08$ & - & $<0.5$ & 0.11 \\
\hline F-3 & 0.04 & 5.1 & 617 & $<0.01$ & 0.01 & - & - & 0.7 & 18.1 & 2.4 & $<0.4$ & $<20$ & - & 0.09 & - & $<0.2$ & 0.19 \\
\hline F-4 & 0.02 & 10.5 & 978 & 0.2 & $<0.01$ & - & - & $<0.2$ & 112 & 20.3 & $<0.4$ & - & - & 0.6 & - & 0.73 & 0.06 \\
\hline F-5 & 0.31 & 56.0 & 11,370 & 0.80 & 0.07 & - & - & 4.0 & 807 & 31.1 & $<0.4$ & 244 & - & 4.2 & - & 1.4 & 2.32 \\
\hline F-5R & 1.2 & 19.2 & 24,500 & 6.8 & - & 5,840 & 8.3 & 19.4 & 5,990 & 1,580 & 0.07 & 6,270 & 3.4 & 9.1 & 313 & 5.29 & 25.9 \\
\hline F-6R & 0.67 & 7 & 17,500 & 7.3 & - & 6,980 & 10 & 16.6 & 4,950 & 873 & 0.72 & 9,470 & 6.8 & 12 & 19 & 8.38 & 20.5 \\
\hline G-1 & 0.02 & 2.5 & $<10$ & $<0.01$ & $<0.01$ & - & - & $<0.2$ & 40.8 & 5.5 & $<0.4$ & $<20$ & - & 0.2 & - & $<0.01$ & $<0.002$ \\
\hline G-2 & 0.007 & 6.8 & 53 & 0.02 & $<0.01$ & - & - & $<0.2$ & 7.37 & $<0.7$ & $<0.4$ & $<20$ & - & 0.1 & - & $<0.5$ & 0.11 \\
\hline G-3 & 0.04 & 4.0 & 761 & $<0.01$ & $<0.01$ & - & - & 0.5 & 18.7 & 1.7 & $<0.4$ & $<20$ & - & $<0.08$ & - & $<0.2$ & 0.20 \\
\hline G-4 & 0.03 & 6.5 & 939 & 0.2 & $<0.01$ & - & - & 0.2 & 152 & 6.6 & $<0.4$ & - & - & 0.5 & - & 0.58 & 0.08 \\
\hline G-5 & 0.32 & 39.8 & 8,220 & 0.74 & 0.06 & - & - & 4.8 & 1,060 & 27.8 & $<0.4$ & 190 & - & 4.1 & - & 0.9 & 2.19 \\
\hline G-5R & 1.5 & 38.8 & 17,500 & 6.6 & - & 5,110 & 4.4 & 18 & 6,330 & 412 & 0.28 & 8,550 & 2.6 & 12.3 & 434 & 7.82 & 26.9 \\
\hline G-6R & 0.38 & 4.2 & 9,750 & 5 & - & 3,770 & 3.6 & 12 & 3,350 & 506 & 0.27 & 8,940 & 5.7 & 5.4 & 15.9 & 6.95 & 11.6 \\
\hline
\end{tabular}


Appendix 3. Amounts of elements leached in sequential extraction experiments given in $\mathrm{mg} / \mathrm{kg}^{1}$. -Continued ['-', not determined or not applicable; 'ins', insufficient material]

\begin{tabular}{|c|c|c|c|c|c|c|c|c|c|c|c|c|c|}
\hline $\begin{array}{l}\text { Extract } \\
\text { ID }\end{array}$ & Sb & Sc & Se & $\mathrm{SiO}_{2}$ & $\mathrm{Sr}$ & Th & $\mathrm{Ti}$ & TI & U & v & w & $Y$ & $\mathrm{Zn}$ \\
\hline B-1 & $<0.06$ & - & $<0.2$ & $<40$ & 0.58 & - & - & $<0.02$ & $<0.02$ & 0.1 & $<0.1$ & - & 1 \\
\hline B-2 & 0.1 & - & $<0.2$ & $<40$ & 0.20 & - & - & $<0.02$ & $<0.02$ & $<0.6$ & $<0.1$ & - & $<2.3$ \\
\hline B-3 & 1.23 & - & $<0.2$ & 1,380 & $<0.1$ & - & - & $<0.02$ & 0.03 & 0.2 & $<0.1$ & - & $<0.7$ \\
\hline B-4 & 0.42 & - & $<0.2$ & 805 & 0.49 & - & - & $<0.02$ & $<0.02$ & 0.9 & $<0.1$ & - & 2 \\
\hline B-5 & 0.2 & - & 0.7 & 1,740 & 6.48 & - & - & 0.05 & 0.04 & 7.6 & $<0.1$ & - & 18.4 \\
\hline B-5R & 0.22 & 6.4 & 7.4 & - & 69.8 & 1.87 & 1,270 & 0.28 & 0.56 & 56.4 & - & 4.6 & 193 \\
\hline B-6R & 0.2 & 13.1 & 2.3 & - & 111 & 1.03 & 2,640 & 0.32 & 0.53 & 95 & - & 9.1 & 108 \\
\hline C-1 & $<0.06$ & - & $<0.2$ & $<40$ & 0.67 & - & - & $<0.02$ & $<0.02$ & 0.1 & $<0.1$ & - & 1 \\
\hline C-2 & 0.1 & - & $<0.2$ & $<40$ & 0.23 & - & - & $<0.02$ & $<0.02$ & $<0.6$ & $<0.1$ & - & $<2.3$ \\
\hline C-3 & 1.27 & - & $<0.2$ & 1,390 & $<0.1$ & - & - & $<0.02$ & 0.03 & 0.3 & $<0.1$ & - & $<0.7$ \\
\hline C-4 & 0.51 & - & $<0.2$ & 888 & 0.51 & - & - & $<0.02$ & $<0.02$ & 0.8 & $<0.1$ & - & 2 \\
\hline C-5 & 0.2 & - & 1.0 & 2,950 & 6.57 & - & - & 0.02 & 0.03 & 8.9 & $<0.1$ & - & 18.4 \\
\hline C-5R & 0.38 & 6.7 & 7.4 & - & 62.1 & 1.57 & 2,170 & 0.3 & 0.46 & 64.3 & - & 5.3 & 186 \\
\hline C-6R & 0.2 & 13.2 & 2.3 & - & 108 & 1.32 & 2,560 & 0.3 & 0.58 & 90.1 & - & 8.9 & 123 \\
\hline D-1 & $<0.06$ & - & $<0.2$ & $<40$ & 0.73 & - & - & $<0.02$ & $<0.02$ & $<0.1$ & $<0.1$ & - & 0.7 \\
\hline D-2 & 0.1 & - & $<0.2$ & $<40$ & 0.16 & - & - & $<0.02$ & $<0.02$ & $<0.6$ & $<0.1$ & - & $<2.3$ \\
\hline D-3 & 0.74 & - & $<0.2$ & 230 & $<0.1$ & - & - & $<0.02$ & $<0.02$ & $<0.1$ & $<0.1$ & - & $<0.7$ \\
\hline D-4 & 0.2 & - & $<0.2$ & 480 & 0.76 & - & - & $<0.02$ & $<0.02$ & 0.9 & $<0.1$ & - & 7.9 \\
\hline D-5 & 0.1 & - & $<0.7$ & 2,470 & 2.94 & - & - & $<0.02$ & 0.05 & 5.3 & $<0.1$ & - & 6.7 \\
\hline D-5R & 0.1 & 6.5 & 0.31 & - & 153 & 2.34 & 2,160 & 0.17 & 0.5 & 43.3 & - & 7.2 & 54.2 \\
\hline D-6R & 0.07 & 6.6 & $<0.1$ & - & 154 & 1.06 & 1,920 & 0.08 & 0.4 & 40.7 & - & 6.9 & 45.6 \\
\hline E-1 & $<0.06$ & - & $<0.2$ & $<40$ & 0.97 & - & - & $<0.02$ & $<0.02$ & $<0.1$ & $<0.1$ & - & 2.0 \\
\hline E-2 & 0.2 & - & $<0.2$ & 327 & 0.32 & - & - & $<0.02$ & $<0.02$ & $<0.6$ & $<0.1$ & - & 0.5 \\
\hline E-3 & 0.94 & - & $<0.2$ & 371 & 0.17 & - & - & $<0.02$ & 0.04 & 0.2 & $<0.1$ & - & 1 \\
\hline E-4 & 0.2 & - & $<0.2$ & 691 & 1.06 & - & - & $<0.02$ & $<0.02$ & 0.8 & $<0.1$ & - & 3.6 \\
\hline E-5 & 0.1 & - & $<0.7$ & 2,880 & 3.06 & - & - & $<0.02$ & 0.06 & 7.2 & $<0.1$ & - & 15.9 \\
\hline E-5R & 0.2 & 5.1 & 0.52 & - & 137 & 1.99 & 1,900 & 0.16 & 0.47 & 37.4 & - & 5 & 47.5 \\
\hline E-6R & 0.1 & 5.1 & $<0.1$ & - & 170 & 1.24 & 1,940 & 0.08 & 0.48 & 34.6 & - & 5.7 & 19.6 \\
\hline F-1 & $<0.06$ & - & $<0.2$ & $<40$ & 1.00 & - & - & $<0.02$ & $<0.02$ & $<0.1$ & $<0.1$ & - & 0.6 \\
\hline F-2 & 0.1 & - & $<0.2$ & 97.7 & 0.26 & - & - & $<0.02$ & $<0.02$ & $<0.6$ & $<0.1$ & - & $<2.3$ \\
\hline F-3 & 0.69 & - & $<0.2$ & 243 & 0.20 & - & - & $<0.02$ & 0.02 & 0.2 & $<0.1$ & - & 0.1 \\
\hline F-4 & 0.1 & - & $<0.2$ & 527 & 0.94 & - & - & $<0.02$ & $<0.02$ & 1.0 & $<0.1$ & - & 2.6 \\
\hline F-5 & 0.1 & - & $<0.7$ & 3,560 & 3.76 & - & - & $<0.02$ & 0.07 & 7.3 & $<0.1$ & - & 13.2 \\
\hline F-5R & 0.06 & 7.9 & 0.75 & - & 110 & 3.21 & 1,710 & 0.13 & 0.58 & 40.2 & - & 9.9 & 29.7 \\
\hline F-6R & 0.08 & 9.5 & 0.22 & - & 161 & 1.93 & 2,390 & 0.1 & 0.65 & 44.3 & - & 11 & 29.4 \\
\hline G-1 & $<0.06$ & - & $<0.2$ & $<40$ & 0.97 & - & - & $<0.02$ & $<0.02$ & $<0.1$ & $<0.1$ & - & 1 \\
\hline G-2 & 0.1 & - & $<0.2$ & $<40$ & 0.22 & - & - & $<0.02$ & $<0.02$ & $<0.6$ & $<0.1$ & - & $<2.3$ \\
\hline G-3 & 0.70 & - & $<0.2$ & 283 & 0.16 & - & - & $<0.02$ & 0.02 & 0.2 & $<0.1$ & - & 0.1 \\
\hline G-4 & 0.1 & - & $<0.2$ & 550 & 1.28 & - & - & $<0.02$ & $<0.02$ & 1.0 & $<0.1$ & - & 2.4 \\
\hline G-5 & 0.09 & - & $<0.7$ & 2,950 & 3.20 & - & - & $<0.02$ & 0.05 & 6.8 & $<0.1$ & - & 10.8 \\
\hline G-5R & 0.1 & 6.1 & 0.15 & - & 173 & 1.9 & 2,090 & 0.14 & 0.44 & 38.8 & - & 7.3 & 45.8 \\
\hline G-6R & 0.05 & 5.7 & $<0.1$ & - & 149 & 0.89 & 2,100 & $<0.08$ & 0.36 & 29.9 & - & 6.5 & 14.6 \\
\hline
\end{tabular}


Appendix 3. Amounts of elements leached in sequential extraction experiments given in $\mathrm{mg} / \mathrm{kg}^{1}$. -Continued

\begin{tabular}{|c|c|c|c|c|c|c|c|c|c|c|c|c|c|c|c|}
\hline Extract ID & Sample ID & $\begin{array}{l}\text { Extract } \\
\text { Step }\end{array}$ & Lab No & Job No. & $\mathbf{A g}$ & Al & As & $\mathrm{Ba}$ & $\mathrm{Be}$ & $\mathbf{B i}$ & $\mathrm{Ca}$ & Cd & Ce & Co & Cr \\
\hline $\mathrm{H}-1$ & EMV-SED-702 & Extract 1 & $08-1$ & - & $<0.6$ & 9.19 & $<0.2$ & $<0.04$ & 0.01 & $<0.04$ & $<40$ & 0.006 & - & 0.62 & $<0.2$ \\
\hline $\mathrm{H}-2$ & EMV-SED-702 & Extract 2 & $08-2$ & - & $<0.6$ & 59.4 & $<0.2$ & 0.35 & $<0.01$ & $<0.04$ & $<136$ & 0.009 & - & 0.12 & 1.4 \\
\hline $\mathrm{H}-3$ & EMV-SED-702 & Extract 3 & $08-3$ & - & $<0.6$ & 124 & 0.4 & 0.08 & 0.02 & $<0.04$ & $<40$ & $<0.004$ & - & 0.14 & 0.3 \\
\hline $\mathrm{H}-4$ & EMV-SED-702 & Extract 4 & $08-4$ & - & $<0.6$ & 272 & $<0.2$ & 2.14 & 0.01 & $<0.04$ & 219 & 0.01 & - & 0.21 & 0.7 \\
\hline H-5 & EMV-SED-702 & Extract 5 & $08-5$ & - & $<0.6$ & 1,442 & $<0.2$ & 6.32 & 0.06 & 0.07 & 383 & $<0.004$ & - & 1.18 & 20.8 \\
\hline$H-5 R$ & EMV-SED-702 & Residue 5 & C-275607 & MRP-06906 & $<2$ & 31,800 & $<1$ & 144 & 1.3 & $<0.06$ & 8,880 & 0.01 & 11.5 & 5.3 & 50.3 \\
\hline H-6R & EMV-SED-702 & Residue 6 & C-275629 & MRP-06906 & $<2$ & 33,400 & $<1$ & 141 & 1.4 & $<0.06$ & 10,900 & 0.01 & 9.7 & 3.6 & 48.4 \\
\hline $\mathrm{I}-1$ & Ely-SD-09 & Extract 1 & $09-1$ & - & $<0.6$ & 6.08 & $<0.2$ & 0.2 & 0.01 & $<0.04$ & $<40$ & $<0.004$ & - & 0.35 & $<0.2$ \\
\hline $\mathrm{I}-2$ & Ely-SD-09 & Extract 2 & $09-2$ & - & $<0.6$ & 69.0 & $<0.2$ & 0.49 & $<0.01$ & $<0.04$ & $<136$ & 0.02 & - & 0.12 & 1.6 \\
\hline $\mathrm{I}-3$ & Ely-SD-09 & Extract 3 & $09-3$ & - & $<0.6$ & 128 & 0.6 & $<0.04$ & $<0.01$ & $<0.04$ & $<40$ & $<0.004$ & - & 0.12 & 0.7 \\
\hline $\mathrm{I}-4$ & Ely-SD-09 & Extract 4 & $09-4$ & - & $<0.6$ & 162 & $<0.2$ & 2.20 & $<0.01$ & 0.06 & 50.6 & 0.02 & - & 0.24 & 1.3 \\
\hline $\mathrm{I}-5$ & Ely-SD-09 & Extract 5 & $09-5$ & - & 1.99 & 792 & $<0.2$ & 29.4 & 0.03 & 1.63 & $<40$ & $<0.004$ & - & 1.32 & 16.0 \\
\hline $\mathrm{I}-5 \mathrm{R}$ & Ely-SD-09 & Residue 5 & C-275608 & MRP-06906 & $<2$ & 57,600 & 1.2 & 214 & 1.9 & 0.48 & 13,900 & 0.27 & 13.2 & 13.3 & 72.6 \\
\hline $\mathrm{I}-6 \mathrm{R}$ & Ely-SD-09 & Residue 6 & C-275630 & MRP-06906 & $<2$ & 61,600 & $<1$ & 202 & 2.1 & 0.13 & 16,800 & 0.09 & 12.8 & 5.7 & 93.1 \\
\hline $\mathrm{J}-1$ & 1139830-SD & Extract 1 & $10-1$ & - & $<0.6$ & 12.5 & $<0.2$ & $<0.04$ & $<0.01$ & $<0.04$ & $<40$ & 0.09 & - & 2.35 & $<0.2$ \\
\hline $\mathrm{J}-2$ & 1139830-SD & Extract 2 & $10-2$ & - & $<0.6$ & 45.9 & $<0.2$ & 0.1 & $<0.01$ & $<0.04$ & $<136$ & 0.07 & - & 0.39 & 1.0 \\
\hline $\mathrm{J}-3$ & 1139830-SD & Extract 3 & $10-3$ & - & $<0.6$ & 106 & 0.6 & $<0.04$ & $<0.01$ & $<0.04$ & $<40$ & 0.02 & - & 0.31 & 0.6 \\
\hline $\mathrm{J}-4$ & 1139830-SD & Extract 4 & $10-4$ & - & 1.06 & 112 & $<0.2$ & 1.93 & $<0.01$ & 0.08 & 119 & 0.05 & - & 0.47 & 0.4 \\
\hline $\mathrm{J}-5$ & 1139830-SD & Extract 5 & $10-5$ & - & 2.91 & 915 & 0.8 & 20.9 & 0.02 & 2.23 & $<40$ & $<0.004$ & - & 3.73 & 13.5 \\
\hline$J-5 R$ & 1139830-SD & Residue 5 & C-275609 & MRP-06906 & 3.3 & 61,100 & 12.8 & 294 & 2.5 & 1.46 & 20,100 & 11.7 & 14.7 & 77.2 & 64.6 \\
\hline$J-6 R$ & 1139830-SD & Residue 6 & C-275631 & MRP-06906 & $<2$ & 42,400 & 1.2 & 207 & 1.9 & 0.18 & 15,100 & 0.05 & 11.3 & 9.7 & 70.4 \\
\hline K-1 & 04Smith3 & Extract 1 & $11-1$ & - & $<0.6$ & 2.19 & $<0.2$ & $<0.04$ & $<0.01$ & $<0.04$ & $<40$ & $<0.004$ & - & 0.17 & $<0.2$ \\
\hline $\mathrm{K}-2$ & 04Smith3 & Extract 2 & $11-2$ & - & $<0.6$ & 9.48 & $<0.2$ & 0.1 & $<0.01$ & $<0.04$ & $<136$ & 0.02 & - & 0.04 & 1.5 \\
\hline $\mathrm{K}-3$ & 04Smith3 & Extract 3 & $11-3$ & - & $<0.6$ & 26.2 & 0.6 & $<0.04$ & $<0.01$ & $<0.04$ & $<40$ & $<0.004$ & - & 0.03 & 0.4 \\
\hline K-4 & 04Smith3 & Extract 4 & $11-4$ & - & 0.84 & 31.3 & $<0.2$ & 1.42 & $<0.01$ & $<0.04$ & $<40$ & 0.01 & - & 0.07 & $<0.2$ \\
\hline K-5 & 04Smith3 & Extract 5 & $11-5$ & - & 5.23 & 270 & $<0.2$ & 48.0 & $<0.01$ & 2.46 & $<40$ & $<0.004$ & - & 4.38 & 10.1 \\
\hline $\mathrm{K}-5 \mathrm{R}$ & 04Smith3 & Residue 5 & C-275610 & MRP-06906 & $<2$ & 20,200 & $<1$ & 94 & 0.82 & 0.27 & 3,570 & 0.05 & 4.1 & 19.4 & 23.8 \\
\hline K-6R & 04Smith3 & Residue 6 & C- 275632 & MRP-06906 & ins & ins & ins & ins & ins & ins & ins & ins & ins & ins & ins \\
\hline L-1 & CLHN-TP-2 & Extract 1 & $12-1$ & - & $<0.6$ & 2.89 & 1 & $<0.04$ & $<0.01$ & $<0.04$ & 1,230 & 2.49 & - & 0.47 & $<0.2$ \\
\hline L-2 & CLHN-TP-2 & Extract 2 & $12-2$ & - & $<0.6$ & 209 & 0.7 & 1.60 & 0.06 & 10.9 & 38,664 & 9.20 & - & 1.00 & 4.9 \\
\hline L-3 & CLHN-TP-2 & Extract 3 & $12-3$ & - & $<0.6$ & 82.5 & 4.3 & 0.47 & 0.03 & 1.96 & 2,000 & 0.56 & - & 0.13 & 1.0 \\
\hline L-4 & CLHN-TP-2 & Extract 4 & $12-4$ & - & 0.63 & 301 & 3.0 & 2.12 & 0.06 & 1.91 & 296 & 1.05 & - & 0.10 & 0.8 \\
\hline L-5 & CLHN-TP-2 & Extract 5 & $12-5$ & - & 2.59 & 2552 & 0.6 & 2.08 & 0.07 & 1.40 & 66.6 & 4.23 & - & 0.20 & 20.0 \\
\hline L-5R & CLHN-TP-2 & Residue 5 & C-275611 & MRP-06906 & 2 & 56,400 & 43.3 & 180 & 1.1 & 2.04 & 2,400 & 23.2 & 17.6 & 3.5 & 38.5 \\
\hline L-6R & CLHN-TP-2 & Residue 6 & C-275633 & MRP-06906 & $<2$ & 52,200 & $<1$ & 177 & 1.1 & $<0.06$ & 2,490 & $<0.007$ & 17.8 & 0.96 & 42.5 \\
\hline M-1 & blank & Extract 1 & $13-1$ & - & $<0.6$ & $<0.4$ & $<0.2$ & $<0.04$ & $<0.01$ & $<0.04$ & $<40$ & $<0.004$ & - & $<0.004$ & $<0.2$ \\
\hline M-2 & blank & Extract 2 & $13-2$ & - & $<0.6$ & 0.41 & $<0.2$ & $<0.04$ & $<0.01$ & 0.05 & $<136$ & 0.007 & - & $<0.004$ & 2.2 \\
\hline M-3 & blank & Extract 3 & $13-3$ & - & $<0.6$ & $<1.37$ & 0.3 & $<0.04$ & $<0.01$ & $<0.04$ & $<40$ & $<0.004$ & - & $<0.004$ & $<0.2$ \\
\hline M-4 & blank & Extract 4 & $13-4$ & - & $<0.6$ & $<0.69$ & $<0.2$ & $<0.04$ & $<0.01$ & $<0.04$ & $<40$ & $<0.008$ & - & $<0.004$ & $<0.2$ \\
\hline M-5 & blank & Extract 5 & $13-5$ & - & $<0.6$ & $<7.6$ & $<0.2$ & $<0.04$ & $<0.01$ & $<0.04$ & $<40$ & $<0.004$ & - & $<0.004$ & 13.8 \\
\hline $\mathrm{N}-1$ & EMV-SED-LOC05 & Extract 1 & $14-1$ & - & $<0.6$ & 10.4 & $<0.2$ & $<0.04$ & $<0.01$ & $<0.04$ & 213 & 0.01 & - & 1.77 & $<0.2$ \\
\hline $\mathrm{N}-2$ & EMV-SED-LOC05 & Extract 2 & $14-2$ & - & $<0.6$ & 50.7 & $<0.2$ & 0.2 & $<0.01$ & $<0.04$ & $<136$ & 0.02 & - & 0.28 & 0.6 \\
\hline
\end{tabular}


Appendix 3. Amounts of elements leached in sequential extraction experiments given in $\mathrm{mg} / \mathrm{kg}^{1}$. -Continued

\begin{tabular}{|c|c|c|c|c|c|c|c|c|c|c|c|c|c|c|c|c|c|}
\hline Extract ID & Cs & $\mathrm{Cu}$ & $\mathrm{Fe}$ & $\mathbf{G a}$ & $\mathbf{G e}$ & K & La & Li & $\mathbf{M g}$ & Mn & Mo & $\mathrm{Na}$ & $\mathbf{N b}$ & $\mathbf{N i}$ & $\mathbf{P}$ & $\mathbf{P b}$ & $\mathbf{R b}$ \\
\hline $\mathrm{H}-1$ & 0.02 & 2.9 & $<10$ & $<0.01$ & $<0.01$ & - & - & $<0.2$ & 37.2 & 3.0 & $<0.4$ & $<20$ & - & 0.3 & - & $<0.01$ & $<0.002$ \\
\hline $\mathrm{H}-2$ & 0.007 & 7.2 & 38 & 0.02 & $<0.01$ & - & - & $<0.2$ & 5.72 & $<0.7$ & $<0.4$ & $<20$ & - & 0.08 & - & $<0.5$ & 0.10 \\
\hline H-3 & 0.05 & 5.0 & 686 & $<0.01$ & $<0.01$ & - & - & 0.8 & 24.2 & 1.1 & $<0.4$ & $<20$ & - & 0.2 & - & $<0.2$ & 0.24 \\
\hline $\mathrm{H}-4$ & 0.04 & 10.4 & 1,160 & 0.2 & $<0.01$ & - & - & $<0.2$ & 80.2 & 6.2 & $<0.4$ & - & - & 0.4 & - & 0.52 & 0.10 \\
\hline $\mathrm{H}-5$ & 0.33 & 59.1 & 12,270 & 0.67 & 0.08 & - & - & 3.4 & 714 & 25.0 & $<0.4$ & 346 & - & 3.5 & - & 1.5 & 2.84 \\
\hline $\mathrm{H}-5 \mathrm{R}$ & 1.5 & 39.4 & 25,400 & 6.5 & - & 5,660 & 5.8 & 18.6 & 6,350 & 1,080 & 0.2 & 6,590 & 2.6 & 11 & 663 & 6.4 & 29 \\
\hline$H-6 R$ & 0.58 & 3.6 & 17,100 & 5.6 & - & 4,860 & 4.7 & 15.8 & 4,590 & 1,280 & 0.67 & 7,790 & 6.7 & 9.5 & 19.2 & 9.13 & 16.8 \\
\hline $\mathrm{I}-1$ & 0.04 & 6.3 & $<10$ & $<0.01$ & 0.01 & - & - & $<0.2$ & 8.73 & 1.2 & $<0.4$ & $<20$ & - & 0.2 & - & $<0.01$ & $<0.002$ \\
\hline $\mathrm{I}-2$ & 0.009 & 35.0 & 48 & 0.02 & $<0.01$ & - & - & $<0.2$ & 2.45 & $<0.7$ & $<0.4$ & 19.5 & - & 0.1 & - & $<0.5$ & 0.16 \\
\hline I-3 & 0.04 & 22.4 & 2,150 & $<0.01$ & $<0.01$ & - & - & $<0.2$ & 7.57 & 0.8 & $<0.4$ & $<20$ & - & $<0.08$ & - & $<0.2$ & 0.12 \\
\hline I-4 & 0.03 & 45.4 & 1,690 & 0.2 & $<0.01$ & - & - & $<0.2$ & 34.4 & 2.7 & $<0.4$ & - & - & 0.2 & - & 1.1 & 0.03 \\
\hline I-5 & 0.40 & 371 & 43,170 & 0.94 & 0.24 & - & - & 1.8 & 296 & 12.1 & 6.43 & 401 & - & 1.8 & - & 18.0 & 11.3 \\
\hline$I-5 R$ & 1.5 & 2,640 & 99,900 & 14.2 & - & 10,300 & 6.4 & 11.7 & 8,400 & 1,190 & 25.2 & 16,800 & 7.7 & 11.3 & 3,100 & 40.8 & 34.1 \\
\hline$I-6 R$ & 0.98 & 86.3 & 24,100 & 13.1 & - & 9,500 & 6.1 & 11.3 & 7,500 & 1,290 & 24.3 & 19,400 & 7.8 & 10.2 & 28.8 & 33.2 & 28.6 \\
\hline $\mathrm{J}-1$ & 0.06 & 27.5 & $<10$ & $<0.01$ & $<0.01$ & - & - & $<0.2$ & 15.3 & 3.3 & $<0.4$ & $<20$ & - & 0.3 & - & $<0.01$ & $<0.002$ \\
\hline $\mathrm{J}-2$ & 0.01 & 60.2 & 44 & 0.02 & $<0.01$ & - & - & 0.3 & 2.20 & $<0.7$ & $<0.4$ & $<20$ & - & $<0.08$ & - & $<0.5$ & 0.16 \\
\hline $\mathrm{J}-3$ & 0.04 & 40.6 & 1,730 & $<0.01$ & $<0.01$ & - & - & $<0.2$ & 7.09 & 0.8 & $<0.4$ & $<20$ & - & $<0.08$ & - & $<0.2$ & 0.23 \\
\hline $\mathrm{J}-4$ & $<0.004$ & 78.4 & 1,510 & 0.2 & $<0.01$ & - & - & $<0.2$ & 24.6 & 2.3 & $<0.4$ & - & - & 0.1 & - & 2.0 & 0.004 \\
\hline $\mathrm{J}-5$ & 0.12 & 513 & 55,570 & 1.1 & 0.36 & - & - & 1.2 & 414 & 18.5 & 3.42 & 318 & - & 1.2 & - & 36.9 & 8.10 \\
\hline$J-5 R$ & 1.7 & 13,900 & 272,000 & 17.7 & - & 14,600 & 6.7 & 17.7 & 12,900 & 1,510 & 35.9 & 12,700 & 16 & 16.7 & 6,720 & 31.8 & 49.6 \\
\hline J-6R & 0.98 & 110 & 37,600 & 9.9 & - & 10,100 & 5 & 13.4 & 7,180 & 1,090 & 8.8 & 9,150 & 16 & 13.6 & 51.2 & 16 & 33.2 \\
\hline K-1 & 0.02 & 5.5 & $<10$ & $<0.01$ & $<0.01$ & - & - & $<0.2$ & 32.2 & 3.5 & $<0.4$ & $<20$ & - & $<0.08$ & - & $<0.01$ & 0.07 \\
\hline K-2 & 0.009 & 27.2 & 36 & 0.02 & $<0.01$ & - & - & $<0.2$ & 2.32 & $<0.7$ & $<0.4$ & $<20$ & - & $<0.08$ & - & $<0.5$ & 0.17 \\
\hline K-3 & 0.01 & 21.5 & 1,940 & $<0.01$ & $<0.01$ & - & - & $<0.2$ & 3.40 & 0.6 & 0.62 & $<20$ & - & $<0.08$ & - & $<0.2$ & 0.15 \\
\hline K-4 & $<0.004$ & 16.9 & 999 & 0.2 & $<0.01$ & - & - & $<0.2$ & 6.85 & 1.8 & $<0.4$ & - & - & $<0.08$ & - & 1.6 & 0.07 \\
\hline K-5 & 0.24 & 278 & 79,570 & 0.95 & 0.42 & - & - & $<0.2$ & 73.0 & 27.6 & 10.3 & 409 & - & 1.1 & - & 65.2 & 26.6 \\
\hline K-5R & 0.45 & 466 & 89,400 & 7.9 & - & 4,760 & 2.2 & 6 & 3,020 & 482 & 7.7 & 5,060 & 1.8 & 4.3 & 2,360 & 13.2 & 16.4 \\
\hline K-6R & ins & ins & ins & ins & - & ins & ins & ins & ins & ins & ins & ins & ins & ins & ins & ins & ins \\
\hline L-1 & 0.10 & 66.6 & $<10$ & $<0.01$ & $<0.01$ & - & - & $<0.2$ & 45.6 & 30.8 & $<0.4$ & $<20$ & - & 1.4 & - & 0.84 & $<0.002$ \\
\hline L-2 & 0.04 & 399 & 1,250 & 0.1 & 0.01 & - & - & $<0.2$ & 346 & 642 & $<0.4$ & $<20$ & - & 4.1 & - & 511 & 0.28 \\
\hline L-3 & 0.19 & 54.3 & 952 & $<0.01$ & $<0.01$ & - & - & $<0.2$ & 123 & 34.8 & 3.10 & $<20$ & - & 0.5 & - & 185 & 0.88 \\
\hline L-4 & 0.08 & 111 & 768 & 0.37 & 0.02 & - & - & $<0.2$ & 374 & 10.2 & 0.46 & - & - & 0.5 & - & 56.2 & 0.11 \\
\hline L-5 & 0.30 & 95.0 & 2,180 & 1.5 & 0.05 & - & - & 3.9 & 4,180 & 79.8 & $<0.4$ & 136 & - & 1.8 & - & 72.8 & 0.74 \\
\hline L-5R & 2.4 & 1,940 & 36,000 & 29.6 & - & 8,270 & 7.5 & 52.8 & 143,000 & 1,200 & 60.5 & 2,120 & 4 & 15.8 & 32.8 & 18.5 & 31.3 \\
\hline L-6R & 2 & 7 & 17,600 & 28.2 & - & 8,580 & 7.4 & 52.4 & 140,000 & 1,100 & 2.9 & 2,270 & 3.4 & 11.1 & 11.4 & 1.43 & 32.6 \\
\hline M-1 & $<0.004$ & 0.2 & $<10$ & $<0.01$ & $<0.01$ & - & - & $<0.2$ & $<2$ & $<0.04$ & $<0.4$ & $<20$ & - & $<0.08$ & - & $<0.01$ & $<0.002$ \\
\hline M-2 & $<0.004$ & 0.4 & $<10$ & $<0.01$ & $<0.01$ & - & - & $<0.2$ & $<2$ & $<0.7$ & $<0.4$ & $<20$ & - & $<0.08$ & - & $<0.5$ & $<0.002$ \\
\hline M-3 & $<0.004$ & 0.3 & $<10$ & $<0.01$ & $<0.01$ & - & - & $<0.2$ & $<2$ & $<0.04$ & $<0.4$ & $<20$ & - & $<0.08$ & - & $<0.2$ & $<0.02$ \\
\hline M-4 & $<0.004$ & $<0.1$ & $<10$ & $<0.01$ & $<0.01$ & - & - & $<0.2$ & $<2$ & $<0.04$ & $<0.4$ & --- & - & $<0.08$ & - & 0.01 & $<0.002$ \\
\hline M-5 & $<0.004$ & $<0.1$ & $<30$ & 0.03 & $<0.01$ & - & - & $<0.2$ & $<2$ & $<0.3$ & $<0.4$ & $<20$ & - & 0.09 & - & $<0.2$ & $<0.002$ \\
\hline $\mathrm{N}-1$ & 0.02 & 2.3 & 35 & $<0.01$ & $<0.01$ & - & - & $<0.2$ & 93.6 & 7.0 & $<0.4$ & $<20$ & - & 0.7 & - & $<0.01$ & 0.06 \\
\hline $\mathrm{N}-2$ & 0.007 & 8.8 & 65 & 0.02 & $<0.01$ & - & - & $<0.2$ & 7.64 & $<0.7$ & $<0.4$ & $<20$ & - & 0.2 & - & $<0.5$ & 0.11 \\
\hline
\end{tabular}


Appendix 3. Amounts of elements leached in sequential extraction experiments given in $\mathrm{mg} / \mathrm{kg}^{1}$. -Continued ['-', not determined or not applicable; 'ins', insufficient material]

\begin{tabular}{|c|c|c|c|c|c|c|c|c|c|c|c|c|c|}
\hline Extract ID & Sb & Sc & Se & $\mathrm{SiO}_{2}$ & $\mathrm{Sr}$ & Th & $\mathrm{Ti}$ & TI & $\mathbf{U}$ & $\mathbf{v}$ & $\mathbf{W}$ & $Y$ & $\mathrm{Zn}$ \\
\hline $\mathrm{H}-1$ & $<0.06$ & - & $<0.2$ & $<40$ & 0.82 & - & - & $<0.02$ & $<0.02$ & $<0.1$ & $<0.1$ & - & 1 \\
\hline $\mathrm{H}-2$ & 0.1 & - & $<0.2$ & 75.3 & 0.19 & - & - & $<0.02$ & $<0.02$ & $<0.6$ & $<0.1$ & - & $<2.3$ \\
\hline $\mathrm{H}-3$ & 0.66 & - & $<0.2$ & 318 & 0.16 & - & - & $<0.02$ & $<0.02$ & 0.2 & $<0.1$ & - & 0.2 \\
\hline $\mathrm{H}-4$ & 0.2 & - & $<0.2$ & 456 & 0.75 & - & - & $<0.02$ & $<0.02$ & 0.5 & $<0.1$ & - & 2.0 \\
\hline H-5 & 0.09 & - & $<0.7$ & 3,450 & 3.28 & - & - & $<0.02$ & 0.05 & 8.4 & $<0.1$ & - & 7.7 \\
\hline $\mathrm{H}-5 \mathrm{R}$ & 0.09 & 9 & 0.47 & - & 114 & 2.31 & 2,180 & 0.15 & 0.43 & 44.1 & - & 12.6 & 35.5 \\
\hline$H-6 R$ & 0.05 & 7.6 & 0.29 & - & 125 & 1.16 & 2,610 & 0.09 & 0.44 & 37.8 & - & 10.7 & 19.9 \\
\hline I-1 & $<0.06$ & - & $<0.2$ & $<40$ & 0.34 & - & - & $<0.02$ & $<0.02$ & $<0.1$ & $<0.1$ & - & 0.2 \\
\hline $\mathrm{I}-2$ & 0.1 & - & $<0.2$ & 253 & 0.11 & - & - & $<0.02$ & $<0.02$ & 0.1 & $<0.1$ & - & $<2.3$ \\
\hline I-3 & 1.25 & - & $<0.2$ & 1,670 & $<0.1$ & - & - & $<0.02$ & 0.06 & 0.4 & $<0.1$ & - & 0.2 \\
\hline I-4 & 0.2 & - & 0.2 & 699 & 0.24 & - & - & $<0.02$ & $<0.02$ & 1.5 & $<0.1$ & - & 1 \\
\hline I-5 & 0.20 & - & 4.9 & 3,150 & 2.35 & - & - & 0.07 & 0.06 & 25.1 & $<0.1$ & - & 11.7 \\
\hline $\mathrm{I}-5 \mathrm{R}$ & 0.67 & 12.7 & 29 & - & 105 & 2.88 & 3,890 & 0.29 & 0.7 & 113 & - & 9.3 & 139 \\
\hline$I-6 R$ & 0.2 & 13.1 & 2.5 & - & 126 & 1.36 & 3,500 & 0.24 & 0.75 & 96.1 & - & 9.8 & 70 \\
\hline $\mathrm{J}-1$ & $<0.06$ & - & $<0.2$ & $<40$ & 0.22 & - & - & $<0.02$ & $<0.02$ & $<0.1$ & $<0.1$ & - & 15.1 \\
\hline $\mathrm{J}-2$ & 0.1 & - & $<0.2$ & 149 & $<0.1$ & - & - & $<0.02$ & $<0.02$ & $<0.6$ & $<0.1$ & - & 7.6 \\
\hline $\mathrm{J}-3$ & 1.33 & - & $<0.2$ & 1,380 & $<0.1$ & - & - & $<0.02$ & 0.04 & 0.3 & $<0.1$ & - & 4.5 \\
\hline $\mathrm{J}-4$ & 0.20 & - & $<0.2$ & 642 & 0.38 & - & - & $<0.02$ & $<0.02$ & 0.3 & $<0.1$ & - & 8.0 \\
\hline J-5 & 0.32 & - & 6.5 & 3,110 & 5.52 & - & - & 0.08 & 0.06 & 13.3 & $<0.1$ & - & 62.8 \\
\hline $\mathrm{J}-5 \mathrm{R}$ & 2.9 & 10.3 & 37 & - & 171 & 5.02 & 4,130 & 0.66 & 1.46 & 99.3 & - & 19.9 & 2,230 \\
\hline$J-6 R$ & 0.51 & 6.4 & 9.3 & - & 121 & 1.2 & 3,040 & 0.42 & 0.89 & 51.5 & - & 17.2 & 86.2 \\
\hline K-1 & $<0.06$ & - & $<0.2$ & $<40$ & $<0.1$ & - & - & $<0.02$ & $<0.02$ & 0.3 & $<0.1$ & - & 1 \\
\hline $\mathrm{K}-2$ & 0.09 & - & $<0.2$ & 71.3 & $<0.1$ & - & - & $<0.02$ & $<0.02$ & 1.2 & $<0.1$ & - & $<2.3$ \\
\hline $\mathrm{K}-3$ & 1.19 & - & $<0.2$ & 3,530 & $<0.1$ & - & - & $<0.02$ & $<0.02$ & 1.7 & $<0.1$ & - & $<0.7$ \\
\hline K-4 & 0.22 & - & $<0.2$ & 753 & 0.19 & - & - & $<0.02$ & $<0.02$ & 5.4 & $<0.1$ & - & 1 \\
\hline K-5 & 0.36 & - & 6.1 & 2,260 & 6.83 & - & - & 0.63 & 0.06 & 41.4 & $<0.1$ & - & 73.6 \\
\hline K-5R & 0.43 & 2.7 & 16 & - & 32.5 & 1.53 & 784 & 0.26 & 0.38 & 58.6 & - & 3.7 & 169 \\
\hline $\mathrm{K}-6 \mathrm{R}$ & ins & ins & 6.2 & - & ins & ins & ins & ins & ins & ins & - & ins & ins \\
\hline L-1 & $<0.06$ & - & 0.3 & $<40$ & 0.87 & - & - & 0.1 & $<0.02$ & $<0.1$ & $<0.1$ & - & 666 \\
\hline L-2 & 1.61 & - & 0.3 & 1,750 & 33.6 & - & - & 0.06 & 0.60 & $<0.6$ & $<0.1$ & - & 2,338 \\
\hline L-3 & 1.31 & - & $<0.2$ & 693 & 1.39 & - & - & 0.1 & 0.14 & 0.1 & $<0.1$ & - & 312 \\
\hline L-4 & 1.61 & - & 0.4 & 845 & 0.40 & - & - & $<0.02$ & 0.07 & 0.2 & $<0.1$ & - & 298 \\
\hline L-5 & 0.50 & - & 0.8 & 5,790 & $<0.1$ & - & - & $<0.02$ & 0.15 & 5.0 & $<0.1$ & - & 1,005 \\
\hline L-5R & 10.7 & 4 & 2.9 & - & 9.2 & 2.75 & 1,050 & 2.28 & 4.3 & 39.4 & - & 30.5 & 6,480 \\
\hline L-6R & 2.1 & 3.7 & $<0.1$ & - & 10 & 2.02 & 928 & 1.22 & 3.03 & 34.8 & - & 32.1 & 121 \\
\hline M-1 & $<0.06$ & - & $<0.2$ & $<40$ & $<0.1$ & - & - & $<0.02$ & $<0.02$ & $<0.1$ & $<0.1$ & - & 0.3 \\
\hline M-2 & $<0.06$ & - & $<0.2$ & 1,640 & $<0.1$ & - & - & $<0.02$ & $<0.02$ & $<0.6$ & $<0.1$ & - & $<2.3$ \\
\hline M-3 & $<0.06$ & - & $<0.2$ & $<40$ & $<0.1$ & - & - & $<0.02$ & $<0.02$ & $<0.1$ & $<0.1$ & - & $<0.7$ \\
\hline M-4 & $<0.06$ & - & $<0.2$ & $<40$ & $<0.1$ & - & - & $<0.02$ & $<0.02$ & $<0.1$ & $<0.1$ & - & 0.1 \\
\hline M-5 & $<0.06$ & - & $<0.7$ & 3,880 & $<0.1$ & - & - & $<0.02$ & $<0.02$ & $<1.9$ & $<0.1$ & - & $<4.6$ \\
\hline $\mathrm{N}-1$ & $<0.06$ & - & $<0.2$ & $<40$ & 0.65 & - & - & $<0.02$ & $<0.02$ & 0.1 & $<0.1$ & - & 2.3 \\
\hline $\mathrm{N}-2$ & 0.1 & - & $<0.2$ & 540 & 0.20 & - & - & $<0.02$ & $<0.02$ & $<0.6$ & $<0.1$ & - & $<2.3$ \\
\hline
\end{tabular}


Appendix 3. Amounts of elements leached in sequential extraction experiments given in $\mathrm{mg} / \mathrm{kg}^{1}$. -Continued

\begin{tabular}{|c|c|c|c|c|c|c|c|c|c|c|c|c|c|c|c|}
\hline Extract ID & Sample ID & $\begin{array}{l}\text { Extract } \\
\text { Step }\end{array}$ & Lab No & Job No. & $\mathbf{A g}$ & Al & As & $\mathrm{Ba}$ & $\mathrm{Be}$ & $\mathbf{B i}$ & Ca & Cd & Ce & Co & Cr \\
\hline $\mathrm{N}-3$ & EMV-SED-LOC05 & Extract 3 & $14-3$ & - & $<0.6$ & 97.6 & 0.3 & $<0.04$ & $<0.01$ & $<0.04$ & $<40$ & $<0.004$ & - & 0.24 & 0.3 \\
\hline $\mathrm{N}-4$ & EMV-SED-LOC05 & Extract 4 & $14-4$ & - & $<0.6$ & 121 & $<0.2$ & 1.24 & $<0.01$ & $<0.04$ & $<40$ & 0.00 & - & 0.24 & 0.4 \\
\hline $\mathrm{N}-5$ & EMV-SED-LOC05 & Extract 5 & $14-5$ & - & $<0.6$ & 716 & 0.4 & 19.1 & 0.04 & 0.48 & 94.6 & $<0.004$ & - & 1.19 & 14.4 \\
\hline$N-5 R$ & EMV-SED-LOC05 & Residue 5 & C-275612 & MRP-06906 & $<2$ & 45,100 & 4.1 & 122 & 0.93 & 0.32 & 10,400 & 0.38 & 8.4 & 16 & 61.5 \\
\hline N-6R & EMV-SED-LOC05 & Residue 6 & C-275634 & MRP-06906 & $<2$ & 56,100 & $<1$ & 143 & 1.3 & 0.06 & 13,300 & 0.05 & 8.6 & 3.9 & 76.6 \\
\hline O-1 & TP1-S-unox & Extract 1 & $15-1$ & - & $<0.6$ & 53.7 & $<0.2$ & $<0.04$ & $<0.01$ & $<0.04$ & 133 & 0.75 & - & 19.5 & 2.1 \\
\hline $\mathrm{O}-2$ & TP1-S-unox & Extract 2 & $15-2$ & - & $<0.6$ & 847 & $<0.2$ & 0.20 & $<0.01$ & 0.09 & $<136$ & 1.24 & - & 3.84 & 5.8 \\
\hline $\mathrm{O}-3$ & TP1-S-unox & Extract 3 & $15-3$ & - & $<0.6$ & 1,849 & 1 & $<0.04$ & $<0.01$ & 0.21 & $<40$ & 0.33 & - & 19.5 & 13.8 \\
\hline O-4 & TP1-S-unox & Extract 4 & $15-4$ & - & $<0.6$ & 2709 & $<0.2$ & 2.28 & $<0.01$ & 0.11 & 529 & 0.94 & - & 5.88 & 16.5 \\
\hline O-5 & TP1-S-unox & Extract 5 & $15-5$ & - & $<0.6$ & 4,412 & $<0.2$ & 1.15 & 0.03 & 0.40 & 611 & 0.87 & - & 7.10 & 36.2 \\
\hline $\mathrm{O}-5 \mathrm{R}$ & TP1-S-unox & Residue 5 & C-275613 & MRP-06906 & $<2$ & 53,400 & 8.1 & 146 & 0.76 & 0.43 & 9,210 & 13.4 & 22.1 & 325 & 112 \\
\hline O-6R & TP1-S-unox & Residue 6 & C-275635 & MRP-06906 & $<2$ & 73,900 & $<1$ & 200 & 1.3 & 0.1 & 13,100 & 0.4 & 26.5 & 42.6 & 144 \\
\hline P-1 & TP1-S-unox & Extract 1 & $16-1$ & - & $<0.6$ & 62.0 & $<0.2$ & $<0.04$ & 0.01 & $<0.04$ & 229 & 0.66 & - & 19.7 & 2.1 \\
\hline $\mathrm{P}-2$ & TP1-S-unox & Extract 2 & $16-2$ & - & $<0.6$ & 866 & $<0.2$ & 0.24 & $<0.01$ & 0.09 & $<136$ & 1.26 & - & 3.83 & 5.7 \\
\hline P-3 & TP1-S-unox & Extract 3 & $16-3$ & - & $<0.6$ & 1,569 & 1 & $<0.04$ & $<0.01$ & 0.18 & $<40$ & 0.31 & - & 17.6 & 10.4 \\
\hline P-4 & TP1-S-unox & Extract 4 & $16-4$ & - & $<0.6$ & 2149 & $<0.2$ & 1.90 & 0.02 & 0.09 & 312 & 0.77 & - & 5.08 & 13.5 \\
\hline P-5 & TP1-S-unox & Extract 5 & $16-5$ & - & $<0.6$ & 4,292 & $<0.2$ & 0.96 & 0.06 & 0.44 & 819 & 0.86 & - & 7.64 & 41.4 \\
\hline$P-5 R$ & TP1-S-unox & Residue 5 & C-275614 & MRP-06906 & $<2$ & 59,800 & 6.7 & 165 & 0.83 & 0.51 & 9,720 & 17.3 & 25.4 & 328 & 127 \\
\hline P-6R & TP1-S-unox & Residue 6 & C-275636 & MRP-06906 & $<2$ & 75,000 & $<1$ & 206 & 1.3 & 0.1 & 12,900 & 0.27 & 22.1 & 28.8 & 142 \\
\hline Q-1 & TP1-S ox & Extract 1 & $17-1$ & - & $<0.6$ & 2.99 & $<0.2$ & $<0.04$ & $<0.01$ & $<0.04$ & $<40$ & $<0.004$ & - & 0.18 & $<0.2$ \\
\hline Q-2 & TP1-S ox & Extract 2 & $17-2$ & - & $<0.6$ & 12.4 & $<0.2$ & 0.24 & $<0.01$ & $<0.04$ & $<136$ & 0.01 & - & 0.02 & 1.0 \\
\hline Q-3 & TP1-S ox & Extract 3 & $17-3$ & - & $<0.6$ & 25.4 & 0.5 & $<0.04$ & $<0.01$ & $<0.04$ & $<40$ & $<0.004$ & - & 0.03 & 0.2 \\
\hline Q-4 & TP1-S ox & Extract 4 & $17-4$ & - & $<0.6$ & 35.8 & $<0.2$ & 0.92 & $<0.01$ & $<0.04$ & $<40$ & -0.003 & - & 0.006 & 0.3 \\
\hline Q-5 & TP1-S ox & Extract 5 & $17-5$ & - & $<0.6$ & 274 & 0.8 & 13.0 & $<0.01$ & 0.59 & $<40$ & $<0.004$ & - & 3.83 & 15.6 \\
\hline Q-5R & TP1-S ox & Residue 5 & C-275615 & MRP-06906 & $<2$ & 50,600 & 2.6 & 147 & 0.98 & 0.11 & 9,140 & 0.17 & 5.3 & 22.1 & 78.8 \\
\hline Q-6R & TP1-S ox & Residue 6 & C-275637 & MRP-06906 & $<2$ & 60,800 & $<1$ & 158 & 1.2 & 0.1 & 11,000 & 0.02 & 9.7 & 1.5 & 80.6 \\
\hline $\mathrm{R}-1$ & 02ТР3A & Extract 1 & $18-1$ & - & $<0.6$ & 15.5 & $<0.2$ & $<0.04$ & $<0.01$ & $<0.04$ & 868 & 0.04 & - & 0.27 & $<0.2$ \\
\hline $\mathrm{R}-2$ & 02ТP3A & Extract 2 & $18-2$ & - & $<0.6$ & 57.6 & $<0.2$ & $<0.04$ & $<0.01$ & $<0.04$ & $<136$ & 0.03 & - & 0.02 & 1.9 \\
\hline R-3 & 02ТР3A & Extract 3 & $18-3$ & - & $<0.6$ & 55.4 & 0.6 & $<0.04$ & $<0.01$ & $<0.04$ & $<40$ & $<0.004$ & - & 0.007 & 0.3 \\
\hline $\mathrm{R}-4$ & 02ТP3A & Extract 4 & $18-4$ & - & $<0.6$ & 14.9 & 0.2 & 0.1 & $<0.01$ & $<0.04$ & $<40$ & 0.00 & - & $<0.004$ & 0.4 \\
\hline R-5 & 02ТР3A & Extract 5 & $18-5$ & - & 5.43 & 426 & 0.9 & 7.27 & $<0.01$ & 2.27 & $<40$ & $<0.004$ & - & 0.27 & 40.5 \\
\hline$R-5 R$ & 02ТР3А & Residue 5 & C-275616 & MRP-06906 & $<2$ & 42,600 & 8.2 & 21.5 & 0.31 & 0.98 & 6,100 & 0.19 & 1.5 & 6.7 & 82 \\
\hline R-6R & 02ТР3A & Residue 6 & C-275638 & MRP-06906 & $<2$ & 60,700 & $<1$ & 24.3 & 0.43 & 0.59 & 8,030 & 0.08 & 1.1 & 2.7 & 91.3 \\
\hline S-1 & 02ТР3C & Extract 1 & $19-1$ & - & $<0.6$ & 1.16 & 0.3 & $<0.04$ & $<0.01$ & $<0.04$ & $<40$ & $<0.004$ & - & 0.03 & $<0.2$ \\
\hline$S-2$ & 02ТР3C & Extract 2 & $19-2$ & - & $<0.6$ & 12.7 & $<0.2$ & 0.2 & $<0.01$ & $<0.04$ & $<136$ & 0.01 & - & 0.005 & 1.4 \\
\hline$S-3$ & 02ТР3С & Extract 3 & $19-3$ & - & $<0.6$ & 18.1 & 0.7 & $<0.04$ & $<0.01$ & $<0.04$ & $<40$ & $<0.004$ & - & 0.007 & 0.4 \\
\hline S-4 & 02ТP3C & Extract 4 & $19-4$ & - & 2.14 & 19.3 & 1 & 0.67 & $<0.01$ & 0.13 & $<40$ & 0.01 & - & 0.004 & 0.3 \\
\hline S-5 & 02ТР3С & Extract 5 & $19-5$ & - & 8.73 & 313 & 3.0 & 7.16 & $<0.01$ & 5.93 & $<40$ & 0.02 & - & 0.51 & 18.9 \\
\hline S-5R & 02ТР3C & Residue 5 & C-275617 & MRP-06906 & $<2$ & 35,700 & 14.9 & 23.6 & 0.26 & 1.36 & 3,650 & 0.96 & 1 & 43.8 & 71.7 \\
\hline S-6R & 02ТР3C & Residue 6 & C-275639 & MRP-06906 & $<2$ & 46,000 & 6.3 & 29.6 & 0.35 & 0.96 & 4,780 & 1.3 & 1.3 & 47.6 & 93.6 \\
\hline $\mathrm{T}-1$ & 02Ely2A & Extract 1 & $20-1$ & - & $<0.6$ & 25.4 & $<0.2$ & $<0.04$ & $<0.01$ & $<0.04$ & $<40$ & 0.04 & - & 1.96 & $<0.2$ \\
\hline $\mathrm{T}-2$ & 02Ely2A & Extract 2 & $20-2$ & - & $<0.6$ & 55.3 & $<0.2$ & $<0.04$ & $<0.01$ & $<0.04$ & $<136$ & 0.04 & - & 0.16 & 0.5 \\
\hline
\end{tabular}


Appendix 3. Amounts of elements leached in sequential extraction experiments given in $\mathrm{mg} / \mathrm{kg}^{1}$. -Continued

\begin{tabular}{|c|c|c|c|c|c|c|c|c|c|c|c|c|c|c|c|c|c|}
\hline Extract ID & Cs & Cu & $\mathrm{Fe}$ & $\mathbf{G a}$ & $\mathbf{G e}$ & $\mathbf{K}$ & La & Li & $\mathbf{M g}$ & Mn & Mo & $\mathrm{Na}$ & $\mathbf{N b}$ & $\mathrm{Ni}$ & $\mathbf{P}$ & $\mathbf{P b}$ & $\mathbf{R b}$ \\
\hline $\mathrm{N}-3$ & 0.03 & 6.2 & 1,310 & $<0.01$ & $<0.01$ & - & - & $<0.2$ & 17.5 & 0.9 & $<0.4$ & $<20$ & - & 0.1 & - & $<0.2$ & 0.23 \\
\hline $\mathrm{N}-4$ & 0.007 & 7.3 & 1,220 & 0.2 & $<0.01$ & - & - & $<0.2$ & 51.1 & 1.7 & $<0.4$ & - & - & 0.3 & - & 0.2 & 0.06 \\
\hline $\mathrm{N}-5$ & 0.34 & 80.2 & 39,570 & 0.57 & 0.24 & - & - & 1.7 & 358 & 11.9 & 1.23 & 1,500 & - & 2.0 & - & 8.1 & 6.92 \\
\hline N-5R & 1.2 & 873 & 103,000 & 9.2 & - & 8,600 & 4.2 & 9.6 & 6,260 & 442 & 8.8 & 15,100 & 2.5 & 11.6 & 3,020 & 25.4 & 29.1 \\
\hline$N-6 R$ & 0.86 & 264 & 21,200 & 10.9 & - & 9,640 & 4.2 & 13.6 & 7,440 & 530 & 5.8 & 18,600 & 5.1 & 7.9 & 26.3 & 19.8 & 31.2 \\
\hline O-1 & 0.54 & $<0.1$ & 774 & $<0.01$ & $<0.01$ & - & - & 0.5 & 34.8 & 2.4 & $<0.4$ & $<20$ & - & 6.2 & - & $<0.01$ & 0.10 \\
\hline $\mathrm{O}-2$ & 0.11 & 8.2 & 492 & 0.06 & $<0.01$ & - & - & 0.5 & 3.80 & $<0.7$ & $<0.4$ & $<20$ & - & 1.4 & - & $<0.5$ & 0.19 \\
\hline $\mathrm{O}-3$ & 0.32 & 21.8 & 10,800 & $<0.01$ & 0.01 & - & - & $<0.2$ & 12.6 & 0.8 & 0.58 & $<20$ & - & 7.0 & - & 2.6 & 1.79 \\
\hline O-4 & 0.14 & 4.9 & 2,220 & 0.24 & $<0.01$ & - & - & 0.2 & 55.4 & 4.1 & $<0.4$ & - & - & 2.1 & - & 1.9 & 0.28 \\
\hline O-5 & 0.26 & 19.6 & 6,010 & 0.69 & 0.06 & - & - & 4.1 & 820 & 27.6 & $<0.4$ & 576 & - & 3.6 & - & 4.8 & 0.74 \\
\hline O-5R & 3.3 & 570 & 154,000 & 13 & - & 16,200 & 11 & 20.3 & 12,300 & 348 & 6 & 10,800 & 2.4 & 81.2 & 1,260 & 31.3 & 58.9 \\
\hline O-6R & 1.9 & 69.1 & 40,700 & 16.8 & - & 19,800 & 13.1 & 26.8 & 13,100 & 376 & 4.6 & 16,200 & 5.8 & 19.6 & 14.1 & 22.5 & 65.1 \\
\hline P-1 & 0.52 & $<0.1$ & 774 & $<0.01$ & $<0.01$ & - & - & 0.9 & 38.8 & 2.7 & $<0.4$ & $<20$ & - & 6.4 & - & $<0.01$ & 0.04 \\
\hline P-2 & 0.11 & 8.8 & 506 & 0.07 & $<0.01$ & - & - & 0.3 & 4.07 & $<0.7$ & $<0.4$ & $<20$ & - & 1.3 & - & $<0.5$ & 0.19 \\
\hline P-3 & 0.31 & 20.1 & 8,700 & $<0.01$ & $<0.01$ & - & - & $<0.2$ & 9.64 & 0.7 & 0.49 & $<20$ & - & 6.2 & - & 2.4 & 1.78 \\
\hline P-4 & 0.12 & 3.8 & 2,210 & 0.26 & $<0.01$ & - & - & $<0.2$ & 50.7 & 3.5 & $<0.4$ & - & - & 1.8 & - & 1.6 & 0.26 \\
\hline P-5 & 0.28 & 22.3 & 6,580 & 0.71 & 0.07 & - & - & 3.3 & 872 & 28.3 & $<0.4$ & 612 & - & 4.1 & - & 5.1 & 0.79 \\
\hline P-5R & 3.6 & 640 & 159,000 & 14.6 & - & 17,500 & 12.6 & 22 & 14,300 & 378 & 8.4 & 11,600 & 2.8 & 82.2 & 1,810 & 25.2 & 67.2 \\
\hline P-6R & 1.9 & 50.8 & 29,700 & 17.1 & - & 20,300 & 11.1 & 25.2 & 12,900 & 360 & 5 & 16,600 & 5.6 & 12.8 & 17.1 & 22.6 & 66.2 \\
\hline Q-1 & 0.09 & 0.4 & $<10$ & $<0.01$ & $<0.01$ & - & - & $<0.2$ & 44.6 & 2.1 & $<0.4$ & $<20$ & - & $<0.08$ & - & $<0.01$ & $<0.002$ \\
\hline $\mathrm{Q}-2$ & 0.02 & 1.7 & 36 & 0.02 & $<0.01$ & - & - & $<0.2$ & 2.57 & $<0.7$ & $<0.4$ & $<20$ & - & $<0.08$ & - & $<0.5$ & 0.10 \\
\hline Q-3 & 0.09 & 1.1 & 581 & $<0.01$ & $<0.01$ & - & - & $<0.2$ & 3.84 & 0.2 & $<0.4$ & $<20$ & - & $<0.08$ & - & $<0.2$ & 0.18 \\
\hline Q-4 & $<0.004$ & 1.0 & 710 & 0.46 & $<0.01$ & - & - & $<0.2$ & 11.3 & 0.3 & $<0.4$ & - & - & $<0.08$ & - & 0.1 & $<0.002$ \\
\hline Q-5 & 0.15 & 35.7 & 22,470 & 0.64 & 0.2 & - & - & 0.3 & 128 & 13.6 & 4.84 & 1,280 & - & 1.7 & - & 13.7 & 7.38 \\
\hline Q-5R & 1 & 49.7 & 44,700 & 11.5 & - & 12,400 & 2.7 & 10.2 & 5,740 & 274 & 6.9 & 13,200 & 2.1 & 8.6 & 750 & 17.3 & 37.8 \\
\hline Q-6R & 0.98 & 7.8 & 6,990 & 12.5 & - & 13,900 & 4.7 & 13.6 & 5,940 & 217 & 3.2 & 17,500 & 2.3 & 1.9 & 16 & 21.7 & 44.4 \\
\hline R-1 & 0.14 & 19.6 & $<10$ & $<0.01$ & $<0.01$ & - & - & $<0.2$ & 31.8 & 0.9 & $<0.4$ & $<20$ & - & 0.08 & - & $<0.01$ & $<0.002$ \\
\hline $\mathrm{R}-2$ & 0.02 & 26.1 & 12 & 0.03 & $<0.01$ & - & - & $<0.2$ & $<2$ & $<0.7$ & $<0.4$ & $<20$ & - & $<0.08$ & - & $<0.5$ & 0.11 \\
\hline R-3 & 0.06 & 7.0 & 1,040 & $<0.01$ & $<0.01$ & - & - & $<0.2$ & $<2$ & $<0.04$ & 1.66 & $<20$ & - & $<0.08$ & - & $<0.2$ & 0.06 \\
\hline $\mathrm{R}-4$ & $<0.004$ & 7.2 & 803 & 0.1 & 0.02 & - & - & $<0.2$ & $<2$ & 0.04 & 1.03 & - & - & $<0.08$ & - & 0.1 & 0.08 \\
\hline R-5 & 0.98 & 117 & 60,070 & 2.5 & 0.40 & - & - & 0.4 & $<2$ & 1.5 & 16.8 & 4,290 & - & 0.4 & - & 21.0 & 31.6 \\
\hline R-5R & 1.7 & 1,360 & 138,000 & 10.1 & - & 8,000 & 0.62 & 3.5 & 8,450 & 455 & 19.6 & 22,600 & $<0.1$ & 1.9 & 3,060 & 36.3 & 25.7 \\
\hline R-6R & 2.4 & 52.9 & 30,600 & 11 & - & 8,360 & 0.47 & 7.6 & 9,350 & 410 & 8.5 & 32,600 & 0.54 & 7.7 & 42.2 & 56.2 & 22.6 \\
\hline S-1 & 0.01 & 3.0 & $<10$ & $<0.01$ & $<0.01$ & - & - & $<0.2$ & 2.07 & 0.2 & $<0.4$ & $<20$ & - & $<0.08$ & - & $<0.01$ & $<0.002$ \\
\hline S-2 & 0.008 & 10.3 & 13 & 0.02 & $<0.01$ & - & - & $<0.2$ & $<2$ & $<0.7$ & $<0.4$ & $<20$ & - & $<0.08$ & - & $<0.5$ & 0.09 \\
\hline S-3 & 0.04 & 5.6 & 501 & $<0.01$ & $<0.01$ & - & - & $<0.2$ & $<2$ & $<0.04$ & 1.23 & $<20$ & - & $<0.08$ & - & 0.8 & 0.10 \\
\hline S-4 & $<0.004$ & 8.8 & 959 & 0.2 & $<0.01$ & - & - & $<0.2$ & $<2$ & 0.06 & 2.43 & - & - & $<0.08$ & - & 2.4 & $<0.002$ \\
\hline S-5 & 0.14 & 106 & 29,070 & 0.90 & 0.20 & - & - & 0.2 & $<2$ & 0.8 & 48.8 & 681 & - & 0.4 & - & 44.4 & 9.67 \\
\hline S-5R & 0.86 & 1,410 & 210,000 & 9.5 & - & 7,530 & 0.54 & 7.1 & 2,170 & 168 & 44.5 & 12,100 & 0.2 & 11 & 637 & 31.2 & 18.1 \\
\hline S-6R & 1 & 465 & 214,000 & 12.7 & - & 11,500 & 0.68 & 12 & 3,340 & 260 & 20.1 & 15,600 & 0.52 & 12.9 & 45.1 & 36 & 24.1 \\
\hline $\mathrm{T}-1$ & 0.32 & 47.5 & 11 & $<0.01$ & $<0.01$ & - & - & 0.2 & 132 & 5.9 & $<0.4$ & $<20$ & - & 0.5 & - & $<0.01$ & $<0.002$ \\
\hline $\mathrm{T}-2$ & 0.04 & 47.1 & 22 & 0.03 & $<0.01$ & - & - & $<0.2$ & 6.59 & $<0.7$ & $<0.4$ & $<20$ & - & $<0.08$ & - & $<0.5$ & 0.15 \\
\hline
\end{tabular}


Appendix 3. Amounts of elements leached in sequential extraction experiments given in $\mathrm{mg} / \mathrm{kg}^{1}$. -Continued

\begin{tabular}{|c|c|c|c|c|c|c|c|c|c|c|c|c|c|}
\hline Extract ID & $\mathbf{S b}$ & Sc & $\mathrm{Se}$ & $\mathrm{SiO}_{2}$ & $\mathrm{Sr}$ & Th & $\mathrm{Ti}$ & $\mathrm{TI}$ & $\mathbf{U}$ & $\mathbf{V}$ & $\mathbf{W}$ & $Y$ & $\mathrm{Zn}$ \\
\hline $\mathrm{N}-3$ & 1.10 & - & $<0.2$ & 1,360 & $<0.1$ & - & - & $<0.02$ & 0.03 & 0.4 & $<0.1$ & - & 0.1 \\
\hline N-4 & 0.29 & - & $<0.2$ & 637 & 0.55 & - & - & $<0.02$ & $<0.02$ & 0.5 & $<0.1$ & - & 1 \\
\hline N-5 & 0.20 & - & 1.2 & 3,720 & 6.92 & - & - & $<0.02$ & 0.03 & 9.2 & $<0.1$ & - & 16.6 \\
\hline$N-5 R$ & 0.49 & 8.7 & 9.6 & - & 80.2 & 1.9 & 1,630 & 0.3 & 0.5 & 71.3 & - & 5.9 & 275 \\
\hline $\mathrm{N}-6 \mathrm{R}$ & 0.2 & 10.1 & 1.6 & - & 104 & 0.85 & 1,990 & 0.34 & 0.54 & 76.2 & - & 6.9 & 83 \\
\hline O-1 & $<0.06$ & - & $<0.2$ & 210 & 0.26 & - & - & $<0.02$ & $<0.02$ & 0.2 & $<0.1$ & - & 71.0 \\
\hline $\mathrm{O}-2$ & 0.20 & - & $<0.2$ & 1,090 & $<0.1$ & - & - & $<0.02$ & 0.03 & 1.1 & $<0.1$ & - & 59.7 \\
\hline $\mathrm{O}-3$ & 1.38 & - & $<0.2$ & 2,120 & $<0.1$ & - & - & $<0.02$ & 0.08 & 6.2 & $<0.1$ & - & 47.2 \\
\hline $\mathrm{O}-4$ & 0.30 & - & $<0.2$ & 4,970 & 0.36 & - & - & $<0.02$ & 0.04 & 2.2 & $<0.1$ & - & 60.9 \\
\hline O-5 & 0.1 & - & $<0.7$ & 6,120 & 0.60 & - & - & $<0.02$ & 0.12 & 8.1 & $<0.1$ & - & 147 \\
\hline$O-5 R$ & 0.2 & 15.3 & 16 & - & 50.8 & 4.19 & 1,760 & 0.86 & 1.48 & 105 & - & 11 & 1,770 \\
\hline O-6R & 0.2 & 15.7 & 4.4 & - & 73.3 & 2.43 & 2,570 & 0.86 & 1.18 & 121 & - & 15.3 & 143 \\
\hline P-1 & $<0.06$ & - & $<0.2$ & 196 & 0.31 & - & - & $<0.02$ & $<0.02$ & 0.3 & $<0.1$ & - & 75.4 \\
\hline P-2 & 0.20 & - & $<0.2$ & 980 & $<0.1$ & - & - & $<0.02$ & 0.04 & 1.1 & $<0.1$ & - & 69.7 \\
\hline P-3 & 1.26 & - & $<0.2$ & 1,870 & $<0.1$ & - & - & $<0.02$ & 0.07 & 4.3 & $<0.1$ & - & 64.7 \\
\hline P-4 & 0.31 & - & $<0.2$ & 4,060 & 0.26 & - & - & $<0.02$ & 0.04 & 2.4 & $<0.1$ & - & 61.2 \\
\hline P-5 & 0.1 & - & $<0.7$ & 5,600 & 0.74 & - & - & $<0.02$ & 0.11 & 9.9 & $<0.1$ & - & 170 \\
\hline P-5R & 0.2 & 16.8 & 16 & - & 56.7 & 4.5 & 1,990 & 0.96 & 1.59 & 116 & - & 12.5 & 2,670 \\
\hline P-6R & 0.2 & 15.4 & 3.1 & - & 70.6 & 2.03 & 2,480 & 0.89 & 1.09 & 122 & - & 14.5 & 114 \\
\hline Q-1 & $<0.06$ & - & $<0.2$ & $<40$ & 0.19 & - & - & $<0.02$ & $<0.02$ & $<0.1$ & $<0.1$ & - & 0.7 \\
\hline Q-2 & 0.1 & - & $<0.2$ & 44.1 & $<0.1$ & - & - & $<0.02$ & $<0.02$ & $<0.6$ & $<0.1$ & - & $<2.3$ \\
\hline Q-3 & 0.88 & - & $<0.2$ & 2,620 & $<0.1$ & - & - & $<0.02$ & $<0.02$ & 0.3 & $<0.1$ & - & $<0.7$ \\
\hline Q-4 & 0.34 & - & 0.3 & 380 & 0.10 & - & - & $<0.02$ & $<0.02$ & 1.5 & $<0.1$ & - & 0.4 \\
\hline Q-5 & 0.20 & - & 2.3 & 4,200 & 3.99 & - & - & $<0.02$ & $<0.02$ & 11.6 & $<0.1$ & - & 42.0 \\
\hline Q-5R & 0.38 & 9.3 & 3.8 & - & 63 & 0.74 & 1,500 & 0.45 & 0.48 & 76.4 & - & 4.6 & 227 \\
\hline Q-6R & 0.1 & 9.6 & 0.86 & - & 78.2 & 0.85 & 1,240 & 0.53 & 0.56 & 74.7 & - & 5.6 & 56.5 \\
\hline R-1 & $<0.06$ & - & 0.8 & $<40$ & 0.16 & - & - & $<0.02$ & $<0.02$ & 0.5 & $<0.1$ & - & 8.7 \\
\hline R-2 & 0.1 & - & 0.2 & 331 & $<0.1$ & - & - & $<0.02$ & $<0.02$ & 2.3 & $<0.1$ & - & 2.3 \\
\hline R-3 & 1.05 & - & 1.8 & 2,470 & $<0.1$ & - & - & $<0.02$ & $<0.02$ & 2.0 & $<0.1$ & - & 0.2 \\
\hline $\mathrm{R}-4$ & 0.37 & - & 0.9 & 304 & 0.26 & - & - & $<0.02$ & $<0.02$ & 7.7 & $<0.1$ & - & 0.7 \\
\hline R-5 & 0.30 & - & 6.4 & 3,140 & 5.85 & - & - & 0.66 & $<0.02$ & 21.8 & $<0.1$ & - & 13.9 \\
\hline R-5R & 0.61 & 9.6 & 22 & - & 24.4 & $<0.1$ & 1,770 & 0.42 & 0.25 & 68.4 & - & 2.2 & 280 \\
\hline R-6R & 0.1 & 10.3 & 2.6 & - & 34.7 & $<0.1$ & 1,450 & 0.3 & 0.22 & 44.7 & - & 4.5 & 143 \\
\hline S-1 & $<0.06$ & - & 2.6 & $<40$ & $<0.1$ & - & - & $<0.02$ & $<0.02$ & $<0.1$ & $<0.1$ & - & $<0.1$ \\
\hline S-2 & 0.1 & - & 0.3 & 372 & $<0.1$ & - & - & $<0.02$ & $<0.02$ & 0.1 & $<0.1$ & - & $<2.3$ \\
\hline S-3 & 0.68 & - & 4.5 & 2,170 & $<0.1$ & - & - & $<0.02$ & $<0.02$ & 0.5 & $<0.1$ & - & $<0.7$ \\
\hline S-4 & 0.39 & - & 2.6 & 259 & 0.13 & - & - & $<0.02$ & $<0.02$ & 1.9 & $<0.1$ & - & 0.3 \\
\hline S-5 & 0.22 & - & 16.0 & 3,270 & 1.24 & - & - & 0.4 & $<0.02$ & 14.3 & $<0.1$ & - & 13.6 \\
\hline S-5R & 0.33 & 7.6 & 84 & - & 19.1 & 0.13 & 1,040 & 0.5 & 0.35 & 73.2 & - & 1.2 & 352 \\
\hline S-6R & 0.1 & 9.8 & 39 & - & 25.6 & $<0.1$ & 1,130 & 0.66 & 0.43 & 84.3 & - & 2.1 & 425 \\
\hline $\mathrm{T}-1$ & $<0.06$ & - & 0.3 & $<40$ & $<0.1$ & - & - & $<0.02$ & $<0.02$ & 0.7 & $<0.1$ & - & 8.8 \\
\hline $\mathrm{T}-2$ & 0.08 & - & $<0.2$ & 174 & $<0.1$ & - & - & $<0.02$ & $<0.02$ & 1.9 & $<0.1$ & - & 1.7 \\
\hline
\end{tabular}


Appendix 3. Amounts of elements leached in sequential extraction experiments given in $\mathrm{mg} / \mathrm{kg}^{1}$. -Continued

\begin{tabular}{|c|c|c|c|c|c|c|c|c|c|c|c|c|c|c|c|}
\hline Extract ID & Sample ID & Extract Step & Lab No & Job No. & $\mathrm{Ag}$ & Al & As & $\mathrm{Ba}$ & $\mathrm{Be}$ & $\mathrm{Bi}$ & $\mathrm{Ca}$ & Cd & Ce & Co & $\mathrm{Cr}$ \\
\hline $\mathrm{T}-3$ & 02Ely2A & Extract 3 & $20-3$ & - & $<0.6$ & 79.1 & 0.4 & $<0.04$ & $<0.01$ & $<0.04$ & $<40$ & $<0.004$ & - & 0.08 & 0.5 \\
\hline $\mathrm{T}-4$ & 02Ely2A & Extract 4 & $20-4$ & - & $<0.6$ & 73.8 & $<0.2$ & 0.51 & $<0.01$ & $<0.04$ & $<40$ & 0.01 & - & 0.12 & 0.5 \\
\hline $\mathrm{T}-5$ & 02Ely2A & Extract 5 & $20-5$ & - & 4.02 & 348 & 0.4 & 54.3 & $<0.01$ & 2.36 & $<40$ & $<0.004$ & - & 1.42 & 15.4 \\
\hline$T-5 R$ & 02Ely2A & Residue 5 & C-275618 & MRP-06906 & $<2$ & 56,600 & 1.6 & 218 & 1.6 & 0.59 & 13,000 & 0.92 & 15.7 & 17.9 & 89.9 \\
\hline T-6R & 02Ely2A & Residue 6 & C-275640 & MRP-06906 & $<2$ & 75,500 & $<1$ & 252 & 2.2 & 0.16 & 18,600 & 0.1 & 17.2 & 6.5 & 101 \\
\hline U-1 & 02Ely10A & Extract 1 & $21-1$ & - & $<0.6$ & 6.10 & $<0.2$ & 0.42 & $<0.01$ & $<0.04$ & $<40$ & $<0.004$ & - & 0.04 & $<0.2$ \\
\hline $\mathrm{U}-2$ & 02Ely10A & Extract 2 & $21-2$ & - & $<0.6$ & 43.6 & $<0.2$ & 0.68 & $<0.01$ & $<0.04$ & $<136$ & 0.01 & - & 0.009 & 1.4 \\
\hline $\mathrm{U}-3$ & 02Ely10A & Extract 3 & $21-3$ & - & $<0.6$ & 105 & 0.6 & $<0.04$ & $<0.01$ & $<0.04$ & $<40$ & $<0.004$ & - & 0.01 & 0.6 \\
\hline U-4 & 02Ely10A & Extract 4 & $21-4$ & - & 2.56 & 92.7 & $<0.2$ & 2.95 & $<0.01$ & 0.07 & $<40$ & 0.01 & - & 0.06 & 0.7 \\
\hline U-5 & 02Ely10A & Extract 5 & $21-5$ & - & 13.0 & 661 & 0.5 & 43.3 & 0.01 & 7.02 & $<40$ & 0.07 & - & 4.14 & 15.7 \\
\hline U-5R & 02Ely10A & Residue 5 & C-275619 & MRP-06906 & $<2$ & 43,000 & 2.3 & 166 & 0.99 & 3.09 & 9,730 & 1.1 & 14.6 & 36.2 & 92.2 \\
\hline U-6R & 02Ely10A & Residue 6 & C-275641 & MRP-06906 & $<2$ & 60,100 & $<1$ & 229 & 1.4 & 2.52 & 14,800 & 1.3 & 18 & 41.9 & 117 \\
\hline $\mathrm{V}-1$ & 04PKHL9 & Extract 1 & $22-1$ & - & $<0.6$ & 22.5 & $<0.2$ & $<0.04$ & 0.01 & $<0.04$ & 1,240 & 0.12 & - & 19.3 & $<0.2$ \\
\hline $\mathrm{V}-2$ & 04PKHL9 & Extract 2 & $22-2$ & - & $<0.6$ & 76.6 & $<0.2$ & 0.54 & $<0.01$ & $<0.04$ & $<136$ & 0.07 & - & 1.89 & 0.9 \\
\hline$V-3$ & 04PKHL9 & Extract 3 & $22-3$ & - & $<0.6$ & 156 & 1 & $<0.04$ & $<0.01$ & $<0.04$ & $<40$ & $<0.004$ & - & 0.26 & 0.5 \\
\hline$V-4$ & 04PKHL9 & Extract 4 & $22-4$ & - & 3.46 & 53.7 & 0.2 & 4.86 & $<0.01$ & $<0.04$ & $<40$ & 0.01 & - & 0.31 & 0.3 \\
\hline$V-5$ & 04PKHL9 & Extract 5 & $22-5$ & - & 16.1 & 427 & 1 & 26.7 & $<0.01$ & 6.03 & $<40$ & $<0.004$ & - & 5.74 & 10.2 \\
\hline$V-5 R$ & 04PKHL9 & Residue 5 & C- 275620 & MRP-06906 & 3.2 & 21,000 & 5.8 & 171 & 0.65 & 1.17 & 3,440 & 1.1 & 6.8 & 68.2 & 25.9 \\
\hline V-6R & 04PKHL9 & Residue 6 & C-275642 & MRP-06906 & $<2$ & 28,400 & $<1$ & 236 & 1 & 0.37 & 4,830 & 0.36 & 8.4 & 31.8 & 45.6 \\
\hline W-1 & 04PKHL11 & Extract 1 & $23-1$ & - & $<0.6$ & 6.36 & $<0.2$ & $<0.04$ & $<0.01$ & $<0.04$ & 3,390 & 0.04 & - & 1.06 & $<0.2$ \\
\hline $\mathrm{W}-2$ & 04PKHL11 & Extract 2 & $23-2$ & - & $<0.6$ & 16.4 & $<0.2$ & 0.09 & $<0.01$ & $<0.04$ & 113 & 0.02 & - & 0.11 & 1.8 \\
\hline W-3 & 04PKHL11 & Extract 3 & $23-3$ & - & $<0.6$ & 39.6 & 0.4 & $<0.04$ & $<0.01$ & $<0.04$ & 94.1 & $<0.004$ & - & 0.06 & 0.4 \\
\hline W-4 & 04PKHL11 & Extract 4 & $23-4$ & - & 0.70 & 37.5 & $<0.2$ & 0.64 & $<0.01$ & $<0.04$ & $<40$ & 0.01 & - & 0.08 & $<0.2$ \\
\hline W-5 & 04PKHL11 & Extract 5 & $23-5$ & - & 6.43 & 244 & 0.5 & 33.0 & $<0.01$ & 4.68 & $<40$ & $<0.004$ & - & 4.34 & 13.8 \\
\hline W-5R & 04PKHL11 & Residue 5 & C- 275621 & MRP-06906 & $<2$ & 40,700 & 3.1 & 204 & 1.5 & 1.37 & 8,300 & 0.21 & 7.6 & 43.6 & 45.8 \\
\hline W-6R & 04PKHL11 & Residue 6 & C-275643 & MRP-06906 & $<2$ & 48,400 & $<1$ & 235 & 2.1 & 0.14 & 10,500 & 0.03 & 3.8 & 4.2 & 50.1 \\
\hline$X-1$ & NZ-Newmont-A & Extract 1 & $24-1$ & - & $<0.6$ & 3.61 & 2 & $<0.04$ & 0.03 & $<0.04$ & 2,390 & 0.007 & - & 0.69 & $<0.2$ \\
\hline$X-2$ & NZ-Newmont-A & Extract 2 & $24-2$ & - & $<0.6$ & 166 & 0.7 & 16.6 & 0.1 & $<0.04$ & 810 & 0.07 & - & 0.99 & 4.7 \\
\hline$X-3$ & NZ-Newmont-A & Extract 3 & $24-3$ & - & $<0.6$ & 422 & 1 & 8.50 & 0.03 & $<0.04$ & 196 & 0.02 & - & 0.86 & 7.6 \\
\hline$X-4$ & NZ-Newmont-A & Extract 4 & $24-4$ & - & 5.76 & 503 & 2 & 50.4 & 0.1 & $<0.04$ & 78.0 & 0.05 & - & 1.88 & 8.2 \\
\hline$X-5$ & NZ-Newmont-A & Extract 5 & $24-5$ & - & 5.18 & 1,982 & 6.1 & 10.1 & 0.2 & 0.04 & $<40$ & $<0.004$ & - & 1.70 & 26.8 \\
\hline$X-5 R$ & NZ-Newmont-A & Residue 5 & C-275622 & MRP-06906 & 6.9 & 51,300 & 28.2 & 414 & 0.88 & $<0.06$ & 799 & 0.08 & 9.6 & 4.8 & 111 \\
\hline $\mathrm{X}-6 \mathrm{R}$ & NZ-Newmont-A & Residue 6 & C-275644 & MRP-06906 & 4 & 48,800 & 4.7 & 434 & 0.76 & $<0.06$ & 873 & $<0.007$ & 5.6 & 0.39 & 70.4 \\
\hline
\end{tabular}


Appendix 3. Amounts of elements leached in sequential extraction experiments given in $\mathrm{mg} / \mathrm{kg}^{1}$. -Continued

\begin{tabular}{|c|c|c|c|c|c|c|c|c|c|c|c|c|c|c|c|c|c|}
\hline Extract ID & Cs & $\mathrm{Cu}$ & $\mathrm{Fe}$ & $\mathbf{G a}$ & Ge & $K$ & La & Li & $\mathbf{M g}$ & Mn & Mo & $\mathrm{Na}$ & $\mathbf{N b}$ & $\mathrm{Ni}$ & $\mathbf{P}$ & $\mathbf{P b}$ & $\mathbf{R b}$ \\
\hline $\mathrm{T}-3$ & 0.07 & 22.0 & 1,120 & $<0.01$ & $<0.01$ & - & - & $<0.2$ & 7.26 & 0.3 & 0.54 & $<20$ & - & $<0.08$ & - & $<0.2$ & 0.17 \\
\hline $\mathrm{T}-4$ & 0.03 & 20.5 & 1,180 & 0.46 & $<0.01$ & - & - & $<0.2$ & 13.1 & 0.7 & 0.49 & - & - & $<0.08$ & - & 0.07 & 0.15 \\
\hline $\mathrm{T}-5$ & 0.68 & 264 & 53,670 & 1.0 & 0.32 & - & - & 0.4 & 85.9 & 7.8 & 10.4 & 866 & - & 0.7 & - & 19.2 & 30.1 \\
\hline $\mathrm{T}-5 \mathrm{R}$ & 1.4 & 2,250 & 153,000 & 14.4 & - & 11,500 & 8 & 7.1 & 5,620 & 1,360 & 23 & 16,700 & 8.3 & 9.7 & 4,050 & 35.1 & 34 \\
\hline $\mathrm{T}-6 \mathrm{R}$ & 1.3 & 65.9 & 29,300 & 16.2 & - & 13,100 & 8 & 12.4 & 7,060 & 2,720 & 8.6 & 22,400 & 8.8 & 9.6 & 41.1 & 40.1 & 36 \\
\hline U-1 & 0.05 & 7.2 & $<10$ & $<0.01$ & $<0.01$ & - & - & 0.2 & 7.67 & 0.6 & $<0.4$ & $<20$ & - & $<0.08$ & - & $<0.01$ & 0.11 \\
\hline $\mathrm{U}-2$ & 0.02 & 27.3 & 13 & 0.02 & $<0.01$ & - & - & $<0.2$ & $<2$ & $<0.7$ & $<0.4$ & $<20$ & - & $<0.08$ & - & $<0.5$ & 0.16 \\
\hline $\mathrm{U}-3$ & 0.07 & 18.2 & 1,240 & $<0.01$ & $<0.01$ & - & - & $<0.2$ & 3.73 & 0.2 & 1.38 & $<20$ & - & $<0.08$ & - & 0.1 & 0.34 \\
\hline U-4 & 0.06 & 21.1 & 1,350 & 0.30 & $<0.01$ & - & - & $<0.2$ & 13.7 & 0.6 & 1.23 & - & - & 0.1 & - & 1.3 & 0.16 \\
\hline U-5 & 0.45 & 428 & 50,670 & 1.1 & 0.31 & - & - & 0.8 & 142 & 11.1 & 22.3 & 1,260 & - & 1.8 & - & 37.2 & 23.6 \\
\hline U-5R & 2 & 1,630 & 155,000 & 10.4 & - & 8,940 & 7.3 & 9.2 & 6,320 & 1,050 & 23.3 & 10,400 & 5 & 15.6 & 2,420 & 22.2 & 26.7 \\
\hline $\mathrm{U}-6 \mathrm{R}$ & 2.1 & 704 & 117,000 & 13.5 & - & 11,300 & 8.7 & 13.3 & 8,700 & 1,610 & 11.8 & 15,200 & 8.5 & 16.3 & 144 & 37.2 & 32.5 \\
\hline $\mathrm{V}-1$ & 0.05 & 156 & 14 & $<0.01$ & $<0.01$ & - & - & 0.2 & 143 & 6.5 & $<0.4$ & $<20$ & - & 1.0 & - & $<0.01$ & $<0.002$ \\
\hline $\mathrm{V}-2$ & 0.01 & 170 & 35 & 0.03 & $<0.01$ & - & - & $<0.2$ & 7.38 & $<0.7$ & $<0.4$ & $<20$ & - & 0.1 & - & $<0.5$ & 0.13 \\
\hline V-3 & 0.05 & 61.0 & 2,240 & $<0.01$ & $<0.01$ & - & - & $<0.2$ & 6.92 & 0.4 & 1.30 & $<20$ & - & $<0.08$ & - & $<0.2$ & 0.09 \\
\hline V-4 & $<0.004$ & 29.6 & 1,290 & 0.23 & $<0.01$ & - & - & $<0.2$ & 20.9 & 1.0 & 0.82 & - & - & 0.08 & - & 1.9 & 0.10 \\
\hline V-5 & 0.09 & 232 & 44,170 & 0.98 & 0.25 & - & - & 0.2 & 198 & 12.0 & 14.8 & 967 & - & 0.9 & - & 94.8 & 19.1 \\
\hline V-5R & 0.95 & 9,070 & 225,000 & 6.2 & - & 7,750 & 3.2 & 5.7 & 3,320 & 215 & 29.5 & 2,370 & 5.1 & 10.7 & 3,970 & 23.5 & 23.9 \\
\hline V-6R & 1.2 & 2,480 & 161,000 & 7.5 & - & 10,200 & 3.8 & 10.2 & 4,010 & 200 & 18.3 & 3,420 & 7.5 & 9.4 & 146 & 15.8 & 31.4 \\
\hline W-1 & 0.07 & 20.0 & $<10$ & $<0.01$ & $<0.01$ & - & - & 0.2 & 35.0 & 2.3 & $<0.4$ & $<20$ & - & 0.2 & - & $<0.01$ & $<0.002$ \\
\hline W-2 & 0.02 & 32.3 & 23 & 0.03 & $<0.01$ & - & - & $<0.2$ & 2.64 & $<0.7$ & $<0.4$ & $<20$ & - & $<0.08$ & - & $<0.5$ & 0.16 \\
\hline W-3 & 0.03 & 16.0 & 1,160 & $<0.01$ & $<0.01$ & - & - & $<0.2$ & 4.43 & 0.4 & 0.53 & $<20$ & - & $<0.08$ & - & $<0.2$ & 0.14 \\
\hline W-4 & $<0.004$ & 16.9 & 1,290 & 0.36 & $<0.01$ & - & - & $<0.2$ & 8.61 & 1.1 & 0.57 & - & - & $<0.08$ & - & 0.90 & 0.09 \\
\hline W-5 & 0.31 & 282 & 59,470 & 0.97 & 0.38 & - & - & $<0.2$ & 56.6 & 12.5 & 11.8 & 1,100 & - & 0.9 & - & 55.5 & 32.2 \\
\hline W-5R & 0.98 & 5,780 & 168,000 & 14.3 & - & 13,000 & 3.7 & 11 & 6,940 & 211 & 18 & 7,940 & 8.6 & 5.1 & 4,470 & 30.5 & 40.8 \\
\hline W-6R & 0.94 & 666 & 14,900 & 13.6 & - & 14,500 & 1.7 & 16.1 & 8,400 & 191 & 4.3 & 9,470 & 9 & 3.3 & 36.4 & 16.4 & 42.7 \\
\hline X-1 & 0.05 & 3.3 & $<10$ & 0.02 & 0.01 & - & - & 0.8 & 227 & 61.6 & $<0.4$ & 984 & - & 1.2 & - & $<0.01$ & $<0.002$ \\
\hline$X-2$ & 0.01 & 27.0 & 80 & 0.1 & 0.01 & - & - & $<0.2$ & 102 & 493 & $<0.4$ & 35.1 & - & 2.1 & - & 6.7 & 0.27 \\
\hline X-3 & 0.43 & 22.0 & 1,220 & $<0.01$ & $<0.01$ & - & - & $<0.2$ & 70.9 & 383 & 0.42 & $<20$ & - & 1.7 & - & 23.1 & 1.52 \\
\hline$X-4$ & 0.70 & 10.3 & 935 & 0.52 & 0.03 & - & - & 1.9 & 298 & 937 & $<0.4$ & - & - & 4.0 & - & 35.2 & 0.66 \\
\hline$X-5$ & 1.93 & 12.8 & 4,880 & 1.0 & 0.1 & - & - & 9.7 & 2,150 & 284 & 0.46 & 161 & - & 10.2 & - & 14.2 & 1.42 \\
\hline X-5R & 6.8 & 35.5 & 19,800 & 8.1 & - & 33,100 & 6.2 & 97.3 & 4,380 & 272 & 0.53 & 3,680 & 4.4 & 14.2 & 245 & 8.5 & 142 \\
\hline $\mathrm{X}-6 \mathrm{R}$ & 5.6 & 8 & 3,780 & 6.7 & - & 35,600 & 3.2 & 111 & 1,960 & 110 & 0.2 & 4,020 & 4.3 & 3 & 29.5 & 2.72 & 162 \\
\hline
\end{tabular}


Appendix 3. Amounts of elements leached in sequential extraction experiments given in $\mathrm{mg} / \mathrm{kg}^{1}$. -Continued

\begin{tabular}{|c|c|c|c|c|c|c|c|c|c|c|c|c|c|}
\hline Extract ID & Sb & Sc & Se & $\mathrm{SiO}_{2}$ & Sr & Th & $\mathrm{Ti}$ & TI & $\mathbf{U}$ & $\mathbf{v}$ & $\mathbf{w}$ & $Y$ & $\mathrm{Zn}$ \\
\hline $\mathrm{T}-3$ & 1.03 & - & 0.5 & 2,700 & $<0.1$ & - & - & $<0.02$ & $<0.02$ & 2.2 & $<0.1$ & - & 1 \\
\hline $\mathrm{T}-4$ & 0.38 & - & 0.4 & 506 & 0.20 & - & - & $<0.02$ & $<0.02$ & 8.0 & $<0.1$ & - & 1 \\
\hline T-5 & 0.23 & - & 10.7 & 2,990 & 6.88 & - & - & 0.3 & $<0.02$ & 37.4 & $<0.1$ & - & 12.8 \\
\hline T-5R & 0.73 & 14.2 & 32 & - & 89.1 & 3.19 & 5,330 & 0.33 & 0.8 & 139 & - & 10.5 & 283 \\
\hline T-6R & 0.28 & 18.6 & 2.8 & - & 124 & 1.89 & 4,660 & 0.31 & 0.78 & 115 & - & 14.2 & 91.1 \\
\hline U-1 & $<0.06$ & - & 1.1 & $<40$ & 0.14 & - & - & $<0.02$ & $<0.02$ & 0.2 & $<0.1$ & - & $<0.1$ \\
\hline $\mathrm{U}-2$ & 0.08 & - & $<0.2$ & 173 & $<0.1$ & - & - & $<0.02$ & $<0.02$ & 1.8 & $<0.1$ & - & $<2.3$ \\
\hline $\mathrm{U}-3$ & 1.04 & - & 3.4 & 2,290 & $<0.1$ & - & - & $<0.02$ & $<0.02$ & 2.5 & $<0.1$ & - & $<0.7$ \\
\hline U-4 & 0.43 & - & 1.3 & 580 & 0.27 & - & - & $<0.02$ & $<0.02$ & 7.9 & $<0.1$ & - & 0.8 \\
\hline U-5 & 0.29 & - & 21.2 & 3,270 & 6.00 & - & - & 0.2 & 0.02 & 36.9 & $<0.1$ & - & 34.1 \\
\hline $\mathrm{U}-5 \mathrm{R}$ & 0.84 & 13 & 47 & - & 63.5 & 2.6 & 4,060 & 0.24 & 0.77 & 146 & - & 7.2 & 493 \\
\hline U-6R & 0.36 & 17.7 & 27 & - & 97.3 & 2.38 & 4,930 & 0.27 & 0.86 & 168 & - & 11.9 & 557 \\
\hline V-1 & $<0.06$ & - & 1.8 & $<40$ & 0.67 & - & - & $<0.02$ & $<0.02$ & 0.4 & $<0.1$ & - & 13.4 \\
\hline $\mathrm{V}-2$ & 0.07 & - & 0.3 & 239 & 0.16 & - & - & $<0.02$ & $<0.02$ & 1.5 & $<0.1$ & - & 4.5 \\
\hline $\mathrm{V}-3$ & 1.32 & - & 10.4 & 3,410 & $<0.1$ & - & - & $<0.02$ & $<0.02$ & 1.9 & $<0.1$ & - & 1 \\
\hline V-4 & 0.39 & - & 2.7 & 659 & 0.54 & - & - & $<0.02$ & $<0.02$ & 2.9 & $<0.1$ & - & 1 \\
\hline V-5 & 0.69 & - & 15.3 & 3,140 & 11.6 & - & - & 0.3 & $<0.02$ & 12.4 & $<0.1$ & - & 35.7 \\
\hline V-5R & 5 & 3.4 & 100 & - & 48.6 & 1.55 & 1,660 & 0.26 & 0.77 & 41.9 & - & 3.2 & 528 \\
\hline V-6R & 3.2 & 4.4 & 55 & - & 74.2 & 1.07 & 1,140 & 0.32 & 0.78 & 44.3 & - & 4.4 & 337 \\
\hline W-1 & $<0.06$ & - & 0.4 & $<40$ & 0.75 & - & - & $<0.02$ & $<0.02$ & 0.2 & $<0.1$ & - & 3.9 \\
\hline W-2 & 0.09 & - & 0.3 & 441 & 0.19 & - & - & $<0.02$ & $<0.02$ & 0.8 & $<0.1$ & - & 0.2 \\
\hline W-3 & 0.93 & - & 0.7 & 2,660 & $<0.1$ & - & - & $<0.02$ & $<0.02$ & 0.8 & $<0.1$ & - & 0 \\
\hline W-4 & 0.43 & - & 0.8 & 556 & 0.41 & - & - & $<0.02$ & $<0.02$ & 3.6 & $<0.1$ & - & 0.9 \\
\hline W-5 & 0.28 & - & 12.7 & 3,070 & 20.6 & - & - & 0.56 & $<0.02$ & 24.5 & $<0.1$ & - & 27.6 \\
\hline W-5R & 0.93 & 7.5 & 33 & - & 70.4 & 2.84 & 2,680 & 0.62 & 0.71 & 81.9 & - & 5.5 & 239 \\
\hline W-6R & 0.32 & 8.1 & 5.0 & - & 83.5 & 0.33 & 1,850 & 0.6 & 0.55 & 71.9 & - & 5.7 & 53.9 \\
\hline$X-1$ & $<0.06$ & - & $<0.2$ & 254 & 4.20 & - & - & $<0.02$ & $<0.02$ & 0.6 & $<0.1$ & - & 2 \\
\hline$X-2$ & 0.1 & - & $<0.2$ & 728 & 4.92 & - & - & $<0.02$ & $<0.02$ & $<0.6$ & $<0.1$ & - & 15.3 \\
\hline$X-3$ & 1.00 & - & $<0.2$ & 1,770 & 2.03 & - & - & 0.1 & $<0.02$ & 0.8 & 0.81 & - & 10.1 \\
\hline$X-4$ & 0.82 & - & $<0.2$ & 1,060 & 5.25 & - & - & $<0.02$ & $<0.02$ & 2.0 & 0.82 & - & 22.2 \\
\hline$X-5$ & 0.37 & - & 2.7 & 4,240 & $<0.1$ & - & - & $<0.02$ & $<0.02$ & 12.7 & 0.72 & - & 48.2 \\
\hline X-5R & 14.1 & 9.1 & 0.60 & - & 61.3 & 3.55 & 1,870 & 1.88 & 0.78 & 53.5 & - & 5.6 & 109 \\
\hline X-6R & 13.1 & 6.7 & 0.22 & - & 71.1 & 2.5 & 1,740 & 2.03 & 0.78 & 34.6 & - & 4.4 & 28.6 \\
\hline
\end{tabular}

Explanation of results: The concentrations in extracts 1 through 5 are presented as solid concentrations and were calculated from the extraction solution concentration and solid -to-extraction solution ratio. The concentrations in residues remaining after steps 5 (5R) and 6 (6R) are for solids. The sum of the solid phase results for extracts 1 through 5 plus extract $5 R$ should sum to the total mass of the sample. The subtraction of $6 R$ from $5 R$ represents the mass released to aqueous and gaseous phases by step 6 reagents (fig. 5).

${ }^{2}$ Results from ICP-MS analysis for all elements except Se concentrations in residues, which were determined by HG-AAS.

${ }^{3}$ If the concentration of an element was near the detection limit in the blank, concentrations were not corrected. For samples with blank concentrations greater than the detection limit, the concentration in the blank was subtracted from the concentration in the samples for a given extraction step and the detection limit became the concentration in the blank (shown in italics).

${ }^{4}$ Concentrations of $\mathrm{Cr}$ and $\mathrm{SiO}_{2}$ in blanks for steps 2 and 5 were equal to or greater than many extract concentrations. Data are invalid and shown in bold red. 